\title{
SCOPE AND STATUS OF THE CIRCUM-PACIFIC MAP PROJECT
}

\author{
A summary of Circum-Pacific Map Project \\ activities during 1983 and 1984 including \\ regional panel meetings and the 1984 Panel Chairmen's Meeting
}

By

Warren 0. Addicott

U.S. Geological Survey

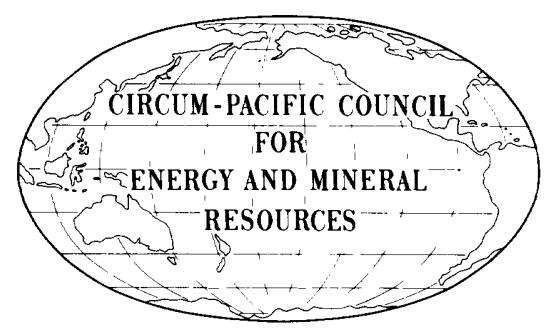

U.S. Geological Survey

OPEN-FILE REPORT 85-267

This report is preliminary and has not been edited or reviewed for conformity with Geological survey standards or nomenclature 
Preface...................................... 1

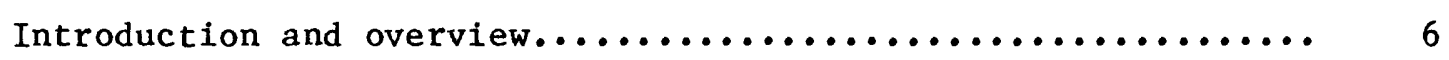

Acknowledgements............................... 8

1984 Panel Chairmen's Meeting........................... 9

Introduction and overview..................... 9

Circum-Pacific Council Chairman's report.............. 11

General Chairman's report...................... 11

Panel Chairmen's reports........................ 13

Northwest Quadrant Panel.................... 13

Antarctica Panel............................ 14

Southwest Quadrant Pane1..................... 14

Southeast Quadrant Panel.................... 16

Northeast Quadrant Panel.................... 17

Map publisher's report.......................... 18

Map publicity............................... 18

Geologic Map Series.............................. 20

overview.................................. 20

Northwest Quadrant........................... 20

Southeast Quadrant............................ 21

Southwest Quadrant............................ 21

Antarctica Region.............................. 21

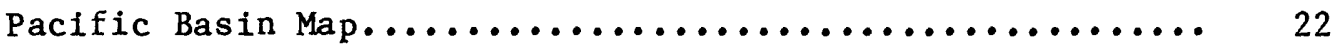

Summary and $\operatorname{Plan} . \ldots \ldots \ldots \ldots \ldots \ldots \ldots \ldots \ldots \ldots \ldots \ldots \ldots \ldots . \ldots \ldots$ 
Plate-Tectonic Map Series............................ 22

Geographic Map Series.............................. 22

Mineral-Resources Map Series.......................... 23

overview..................................... 23

Northeast Quadrant............................... 23

Northwest Quadrant............................... 24

Southwest Quadrant............................... 25

Southeast Quadrant.............................. 25

Antarctica Region............................... 26

Geologic Background for the Series................... 26

Manganese Crusts............................... 26

Geodynamic Map Series............................... 27

Tectonic Map Series................................ 28

overview.................................... 28

Southwest Quadrant............................. 28

Northeast Quadrant............................... 29

Southeast Quadrant............................... 29

Antarctica Region.............................. 30

Northwest Quadrant............................ 30

Basin-Wide Data Sets............................ 31

Energy-Resources Map Series............................ 31

Northeast Quadrant............................. 31

Southeast Quadrant............................. 32

Northwest Quadrant............................. 33 
Antarctica $\operatorname{Region} . \ldots \ldots \ldots \ldots \ldots \ldots \ldots \ldots \ldots \ldots \ldots \ldots \ldots \ldots \ldots \ldots \ldots \ldots$

Southwest Quadrant.............................. 34

Explanatory Notes.............................. 35

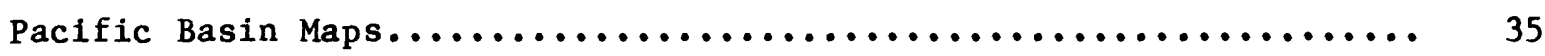

Plate-Tectonic Map............................. 35

Manganese Nodule, Seafloor Sediment, and Sedimentation

Rate Map.................................... 35

Seafloor Sediment Map.......................... 36

Tectonostratigraphic Terrane Map.................... 37

Geologic Map................................. 37

Geodynamic Map................................ 38

Hazards $\operatorname{Map} . \ldots \ldots \ldots \ldots \ldots \ldots \ldots \ldots \ldots \ldots \ldots \ldots \ldots \ldots \ldots \ldots \ldots \ldots \ldots \ldots$

Energy-Resources Map........................... 40

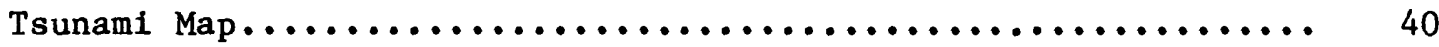

Experimental maps................................ 40

Southeast Asia Basin Evaluation Project................... 42

Background................................... 42

Consideration of Project at 1984 Panel Chairmen's

Review of the Program at the XXI Meeting of CCOP........... 46

IV Circum-Pacific Conference $1986 \ldots \ldots \ldots \ldots \ldots \ldots \ldots \ldots \ldots \ldots \ldots \ldots \ldots$

References Cited.................................... 48 
Figures

Figure 1. Index map showing boundaries of the five 1:10,000,000-scale map sheets.

2. Chairmen of the Circum-Pacific regional panels, June 1983.

3. Circum-Pacific Council Chairman Michel T. Halbouty and Council Director Zhai Guangming of China.

4. Participants in the June 1983 Map Project Meeting.

5. Participants in the June 1984 Map Project Meeting.

6. Circum-Pacific Council and Map Project leaders.

7. Northwest Quadrant Panel meeting, Bandung, Indonesia, December 1984 .

8. Participants in the October 1984 meeting of the Southwest Panel, Apia, Samoa.

9. Participants in the Southeast Quadrant Panel meeting, Santiago, Chile, January 1984.

10. Participants in the Northeast Quadrant Panel meeting, Indianapolis, Indiana, November 1983.

11. Circum-Pacific exhibit at the Geological Society of America Annual Meeting, Reno, Nevada, November 1984.

12. Circum-Pacific Map Project Panel Chairmen's meeting, East-West Center, Honolulu, Hawail, June 1983.

13. Natural hazards map of the Southeast Asian region.

14. Index to map sheets for the Southeast Asia Basin Evaluation Program. 
Tables

Table 1. Acronyms used in this report.

2. Status of incomplete unpublished 1:10,000,000-scale Circum-Pacific Maps as of January 1985.

3. Officers and Directors of the Circum-Pacific Council for Energy and Mineral Resources.

4. Members of the Circum-Pacific regional panels and map consultants.

5. Organizations cooperating with or providing information for the Circum-Pacific Map Project.

6. Participants in the 1983 Panel Chairmen's Meeting, Honolulu, Hawaif.

7. Published Circum-Pacific maps.

8. Schedule for publication of the Circum-Pacific thematic maps, 1984-1989.

9. Participants in the 1984 Panel Chairmen's Meeting, Honolulu, Hawaii.

10. Report of the 1983 Northwest Quadrant Panel Meeting.

11. Report of the 1984 meeting of the Northwest Quadrant Panel.

12. Notes from the 1984 Antarctica Panel meeting.

13. Notes from the 1983 Southwest Quadrant Panel meeting.

14. Notes from the 1984 Southeast Quadrant Panel meeting.

15. Report of the 1983 Northeast Quadrant Panel meeting.

16. Sales of Circum-Pacific Maps through April 30, 1984.

17. Modification of compilation guidelines for the Mineral-Resources Map of the Southwest Quadrant recommended by the Southwest Quadrant panel.

18. Compilation guideline for the Tectonic Map Series.

19. Compilation guidelines for the Energy-Resources Map Series.

20. Letter from Peter B. Humphrey to Michel T. Halbouty concerning a Circum-Pacific hazards map. 
Table 21. Proposed guidelines for a 1:17,000,000-scale Energy-Resources Map of the Pacific Basin.

22. Report of a meeting on the Southeast Asia Project, Madrid, Spain, April 2-4, 1984.

23. Production schedule for the Southeast Asia 1:2,000,000-scale base maps. 
The Circum-Pacific Map Project is a cooperative international effort to compile and publish new geological, geophysical, and resources maps of the Pacific Basin and surrounding continental areas. The maps are designed to show the relationship of known energy and mineral resources to the geology, tectonics, and crustal dynamics of the Pacific region. The latest geologic, geophysical, mineral, and energy data are being compiled at a basic scale of 1:10,000,000 on equal-area map projections. Where feasible, available data are being complemented by new, project-developed data sets such as magnetic lineations, plate-motion vectors, seafloor mineral deposits, and seafloor sediment. Earth scientists from 42 Pacific-region countries are involved in this work.

Covering more than half of the Earth's surface, the project area extends from the Indian Ocean eastward across the Pacific to include most of North and South America. It extends from the Arctic Ocean southward to include the entire continent of Antarctica.

Five overlapping regional maps at a scale of $1: 10,000,000$ form the cartographic base for the project. The base maps include the four quadrants of the Pacific (Northwest, Southwest, Southeast, and Northeast Quadrants) and Antarctica (figure 1). There is also a map of the entire Pacific Basin at a scale of 1:17,000,000. Eight series of maps will be issued by the project. Three complete map series comprising 18 map sheets have already been published: the Geographic, Base, and Plate-Tectonic Maps. One or more map sheets have been published in the Geologic, Mineral-Resources and Geodynamic Map Series. Other thematic map series in preparation include the Tectonic and Energy-Resources Maps (table 2). Special Pacific basin maps include the 1:17,000,000-scale Tectonostratigraphic Terrane Map printed in January 1985 and the Manganese Nodule, Sediment, Sedimentation Rate Map, scheduled for publication during the second quarter of 1985. A final 1:17,000,000-scale map showing the relation of resources to the major geologic and tectonic features of the Pacific basin is also planned. Altogether, 46 map sheets are projected; 24 were published and 4 were in final proof as of January 1985. The maps are being published and distributed by the American Association of Petroleum Geologists (AAPG), P.0. Box 979, Tulsa, Oklahoma 74101, U.S.A.

The framework for the Circum-Pacific Map Project was developed in 1973 by a group of 12 North American geoscientists. The project was officially started during the First Circum-Pacific Conference on Energy and Mineral Resources, which met in Honolulu, Hawaii, in mid-1974 (Halbouty and others, 1976). Actions taken at the conference, sponsored by the AAPG, the Pacific Science Association (PSA), and the Coordinating Committee for offshore Prospecting for Mineral Resources in Asian offshore Areas (CCOP), led to the formation of the Circum-Pacific Council for Energy and Mineral Resources. At the organizational meeting of the Council, Michel $T$. Halbouty was named chairman, and the Map Project, under the chairmanship of John A. Reinemund, was included as a principal activity of the Council. 


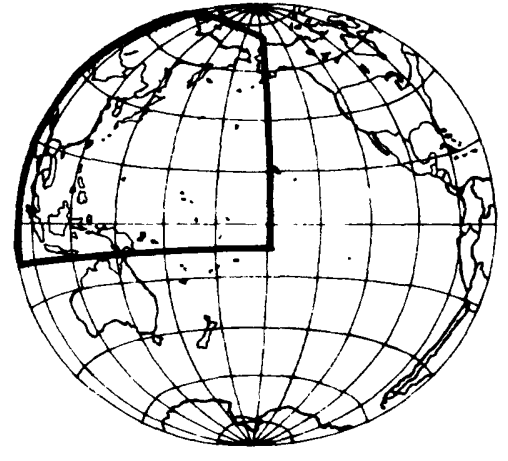

Northwest quadrant

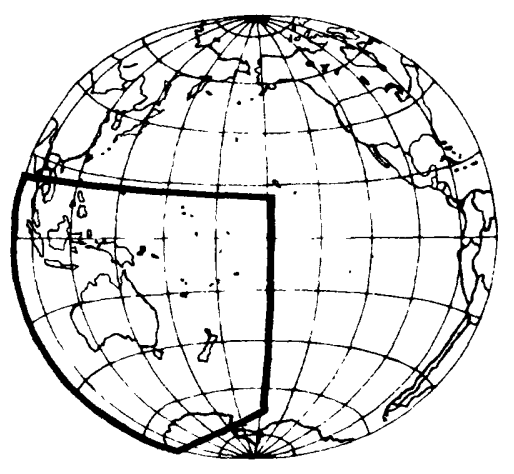

Southwest quadrant

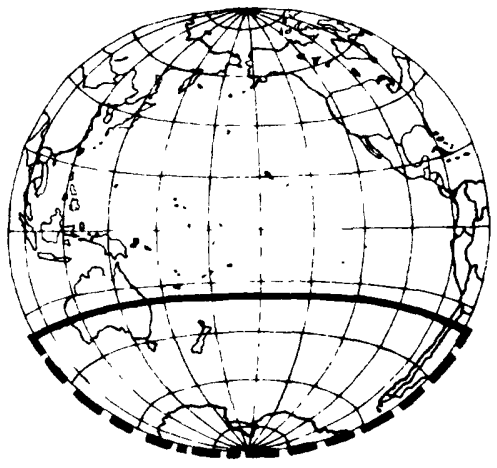

Antarctica sheet

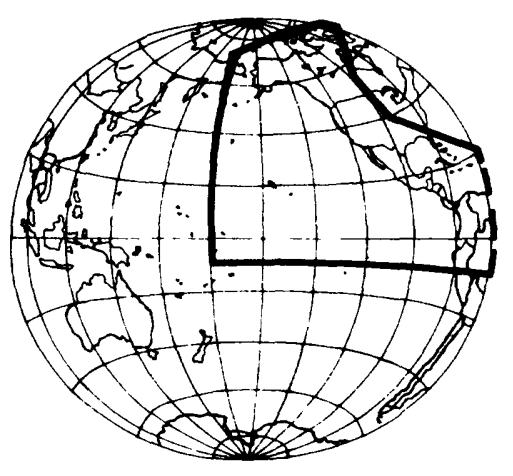

Northeast quadrant

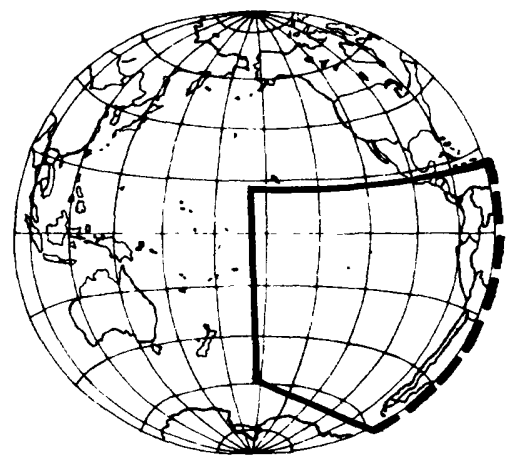

Southeast quadrant

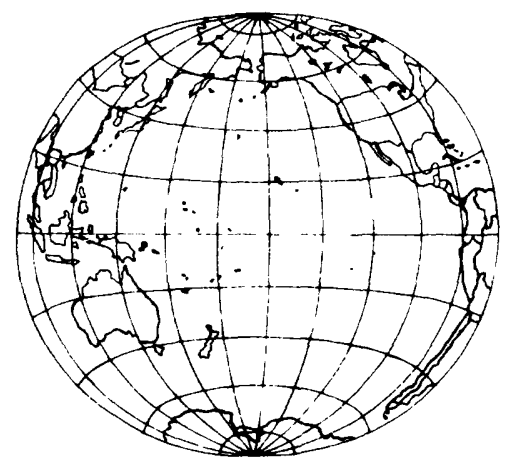

Pacific basin sheet

Figure 1. Index maps showing boundaries of the five 1:10,000,000-scale map sheets and the Pacific Basin Map. A substantial part of the Antarctica sheet is not shown on the index map. 


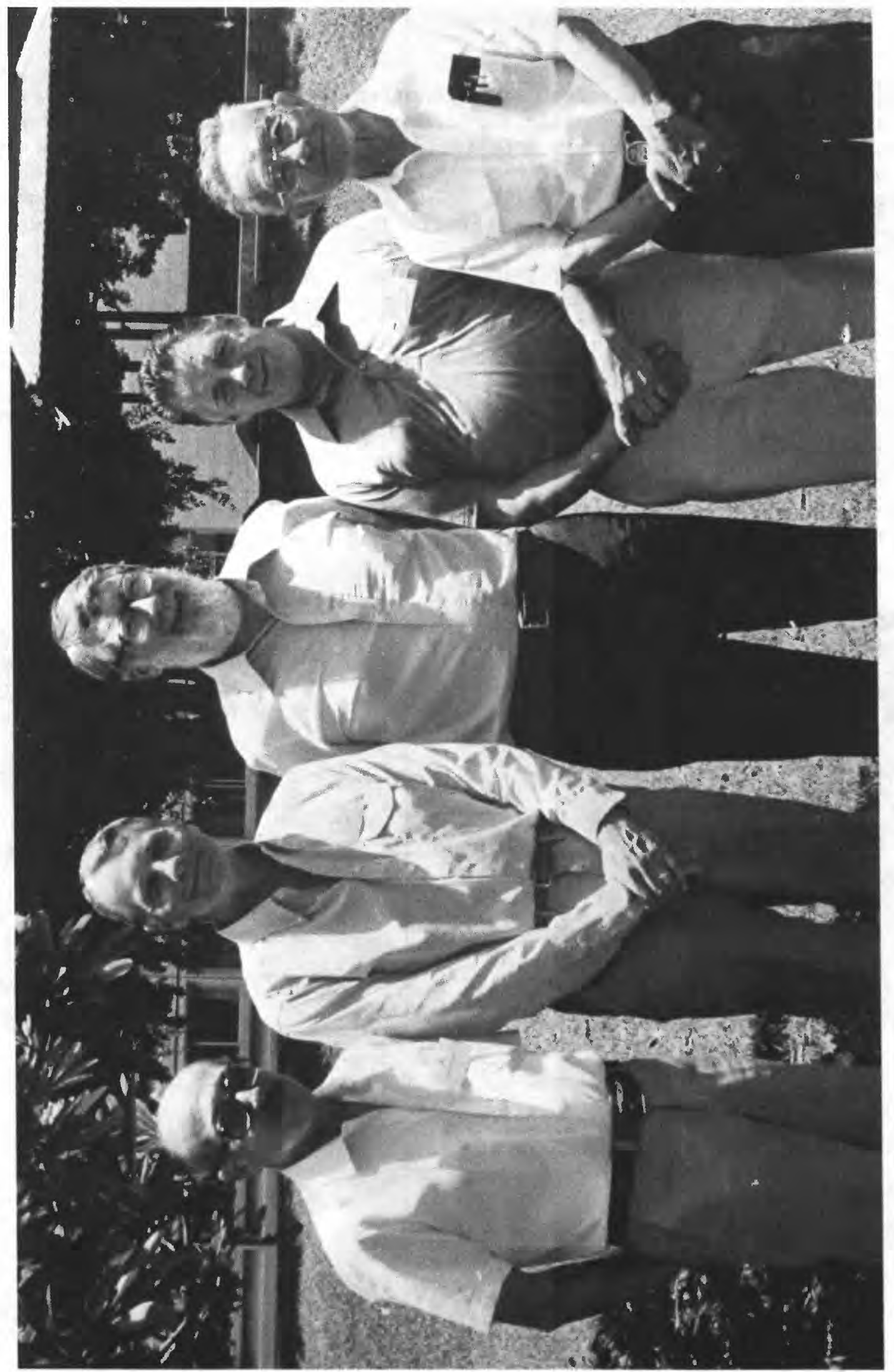

盛

(1) on

욛ㄷㄴ

\%

각

可

टै मे

- 10

幽定要

म

in

फ

(0)

出

प्र

$8+$

담ำ

웅

क

앙

$\Sigma 0$ द

u r

泋

-

论

क न प्रे

1 व

दु ?

4 \%

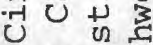

ii

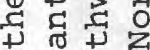

山

○ थ

थै वर

(1) + - 5

द्व हैन

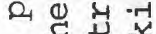

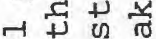

033

ᄃㅇㅇㅇㅝ

-

ब 0 च

म $\rightarrow$ H

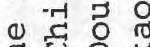

过记

出: 艺迁

○

ป็. ⿷匚⿱⿰㇒一大

E $\rightarrow 0$

.

号

चै

$\dot{N}$

. 
The Circum-Pacific Council promotes scientific interchanges and resource exploration through its quadrennial conferences, the Circum-Pacific Map Project, educational symposia, scientific training seminars, and earth science publication series. At the Third Circum-Pacific Conference in 1982, the Council became affiliated with the AAPG. Halbouty was renamed chairman and president, J. Erick Mack, Jr., was named first vice-president, Alan G. Hatley was named second vice-president, H. Gary Greene was named treasurer, and Mary Stewart was appointed secretary. The officers and directors of the CircumPacific Council under which the Circum-Pacific Map Project operates as a principal subactivity are listed in table 3.

The Circum-Pacific Map Project is organized under five panels of geoscientists (table 4) representing national earth-science organizations, universities, and natural-resource companies. The five panels correspond to the basic map areas (figure 1). Panel chairmen (figure 2) include Chikao Nishiwaki (Northwest Quadrant), H. Frederick Doutch (Southwest Quadrant), Campbell Craddock (Antarctica Region), José Corvalán D. (Southeast Quadrant), and Kenneth J: Drummond (Northeast Quadrant). Drummond succeeded C. A. Burk

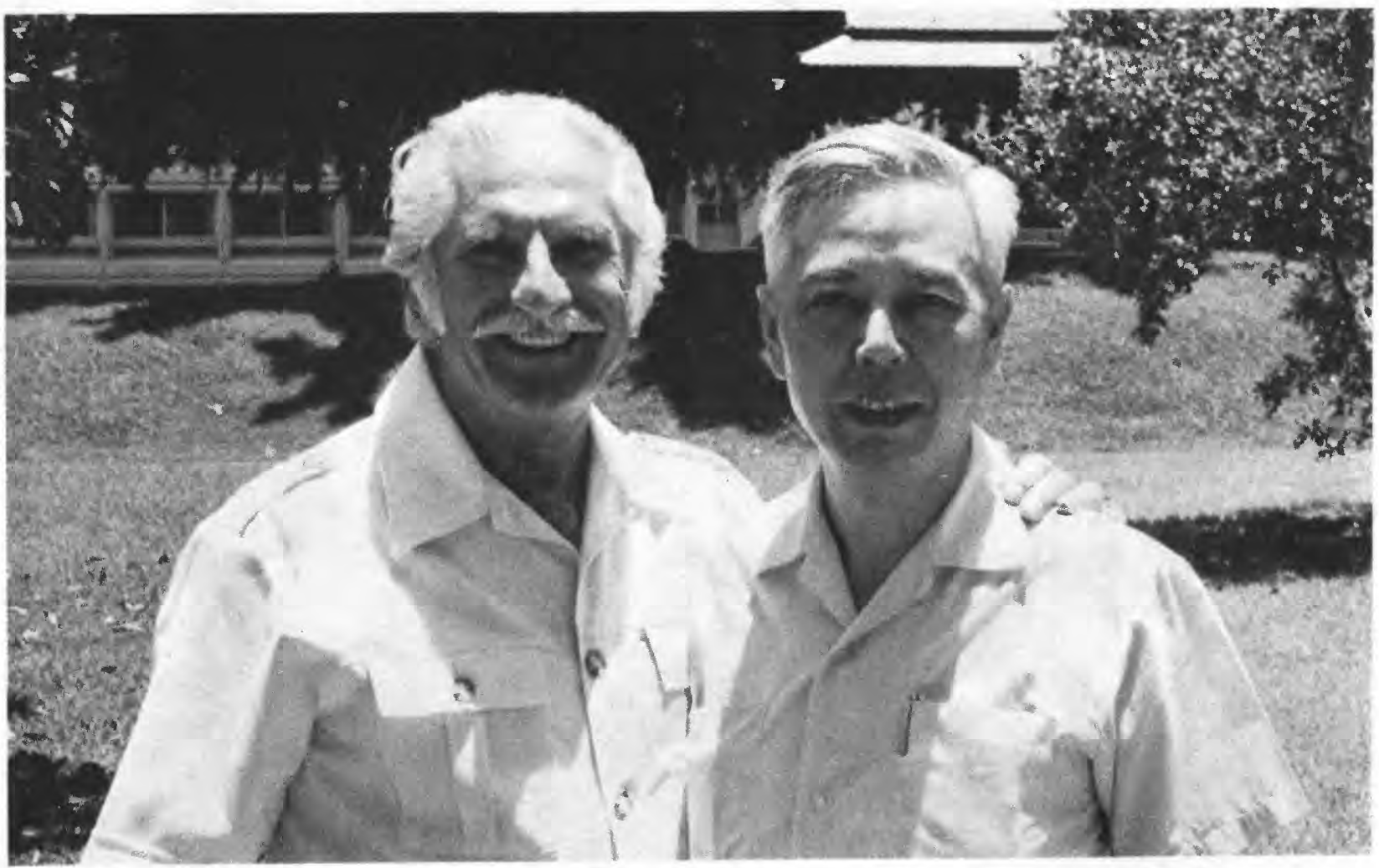

Figure 3. Michel T. Halbouty (left), Chairman and President of the CircumPacific Council, and Zhai Guangming, Council Director from China. 
as chairman of the Northeast Quadrant Panel in 1976, Craddock succeeded F. Alton Wade as chairman of the Antarctica Panel in 1978, and Doutch succeeded Ronald N. Richmond as chairman of the Southwest Quadrant Panel in 1980.

The international context of the Circum-Pacific Map Project is indicated by the broad base of support and involvement by Pacific-region countries. During its 11 years of operation this project has been sustained through appreciable contributions in staffing, data, and services by more than 45 participating countries and some 170 cooperating organizations (table 5).

Project coordination and final cartography is being carried out through the cooperation of the Office of International Geology of the U.S. Geological Survey under the direction of Map Project General Chairman Warren 0. Addicott of Menlo Park, California, with the assistance of George W. Moore, Special Consultant for Marine Geology and Resources. Scientific coordination has been guided by Maurice J. Terman of Reston, Virginia. Project headquarters are located at 345 Middlefield Road, MS 952, Menlo Park, California 94025, U.S.A. John A. Reinemund served as General Chairman of the Map Project from 1974 until 1982, when he was appointed Director. Paul W. Richards was Deputy Chairman of the Project from 1975 until 1979.

An annual meeting of the panel chairmen, committee chairmen, consultants, and representatives from the Circum-Pacific Council for Energy and Mineral Resources (CPCEMR) (figure 3) has been held each year since 1975. This report summarizes actions taken at the 1983 and 1984 Map Project meeting and the status of the project as of January 1985. 


\section{INTRODUCTION AND OVERVIEW}

This report deals with the status of the Circum-Pacific Map Project as of January 1985. The principal focus of this document is the 1984 Panel Chairmen's meeting; important actions taken during the 1983 project Meeting (figure 4, table 5) are included as background information. Resumes of regional panel meetings held during 1983 and 1984 are also included. The status of each thematic map series as of January 1985 and significant developments that have taken place since the previous status report (Addicott, 1983) are summarized. A list of acronyms is included to aid the reader (table $1)$.

Twenty-four maps, including one or more sheets in six of the eight planned map series, had been printed by the beginning of 1985 (table 7). Of the 22 map sheets remaining to be published, 10 had reached the color proof stage and compilation of the other 12 sheets was well-advanced at the beginning of 1985.

During 1984 a schedule for completion of the remaining maps that forecasts completion of the initial phase of the Project by 1989 was developed (table 8). This projection calls for eleven map sheets to be printed in 1985, by which time about 70 percent of the map sheets will have been published.

Principal accomplishments during 1983 and 1984 were publication of the first map sheets in three thematic series: Geologic, Geodynamic, and Minera1Resources. In response to a continuing demand for the already-published maps, the Plate-Tectonic Map of the Antarctica Region and the Pacific Basin were reprinted. Color proofs of four additional map sheets in the Geodynamic Series and three in the Geologic Series were completed during 1984.

In 1983 the Southeast and Northeast Quadrant panels decided to schedule yearly panel meetings as a means of increasing participation in eastern Pacific resources mapping.

The Northeast Quadrant Panel met for the first time in Indianapolis, Indiana, in November 1983. The panel voted to expand membership among the Central American countries along lines suggested by Gabriel Dengo of Guatemala and plans were laid to coordinate the compilation of the Tectonic Map of the Northeast Quadrant.

An organizational meeting of the Southeast Panel was held in Santiago, Chile, in January 1984 with the cooperation and support of the Circum-Pacific Council. An important action taken at that meeting was a reorganization of panel membership and the adoption of new procedures for map compilation and review by the member countries.

The Southwest and Northwest Panels have held regularly scheduled meetings for several years and the Antarctica Regional Panel, which most recently met in Moscow in August 1984, has held informal meetings from time to time. 
A second phase of project work involving detailed geological and resource mapping by the regional panels was initiated in the Northwest quadrant during 1983 and 1984.

A joint IUGS/CCOP proposal for a basin analysis and resources assessment program in Southeast Asia was presented to the Map Committee in 1983 by John A. Reinemund, Director of the Map Project and currently Executive Director of the Circum-Pacific Council. With agreement from the circum-Pacific Council, the Panel Chairmen authorized a six-month feasibility study in the South China Sea area off the coast of Borneo as well as the development of suitable 1:2,000,000-scale base maps for the study. At their 1984 meeting, the Panel Chairmen voted to move ahead with the joint program based in large part on a successful pilot study of that region by Keith Robinson of the U.S. Geological survey. Coordination of CPMP participation in this program will be handled by the Northwest Quadrant Panel. Preparation of seven 1:2,000,000scale base maps by the U.S. Geological Survey was well-advanced by January 1985.

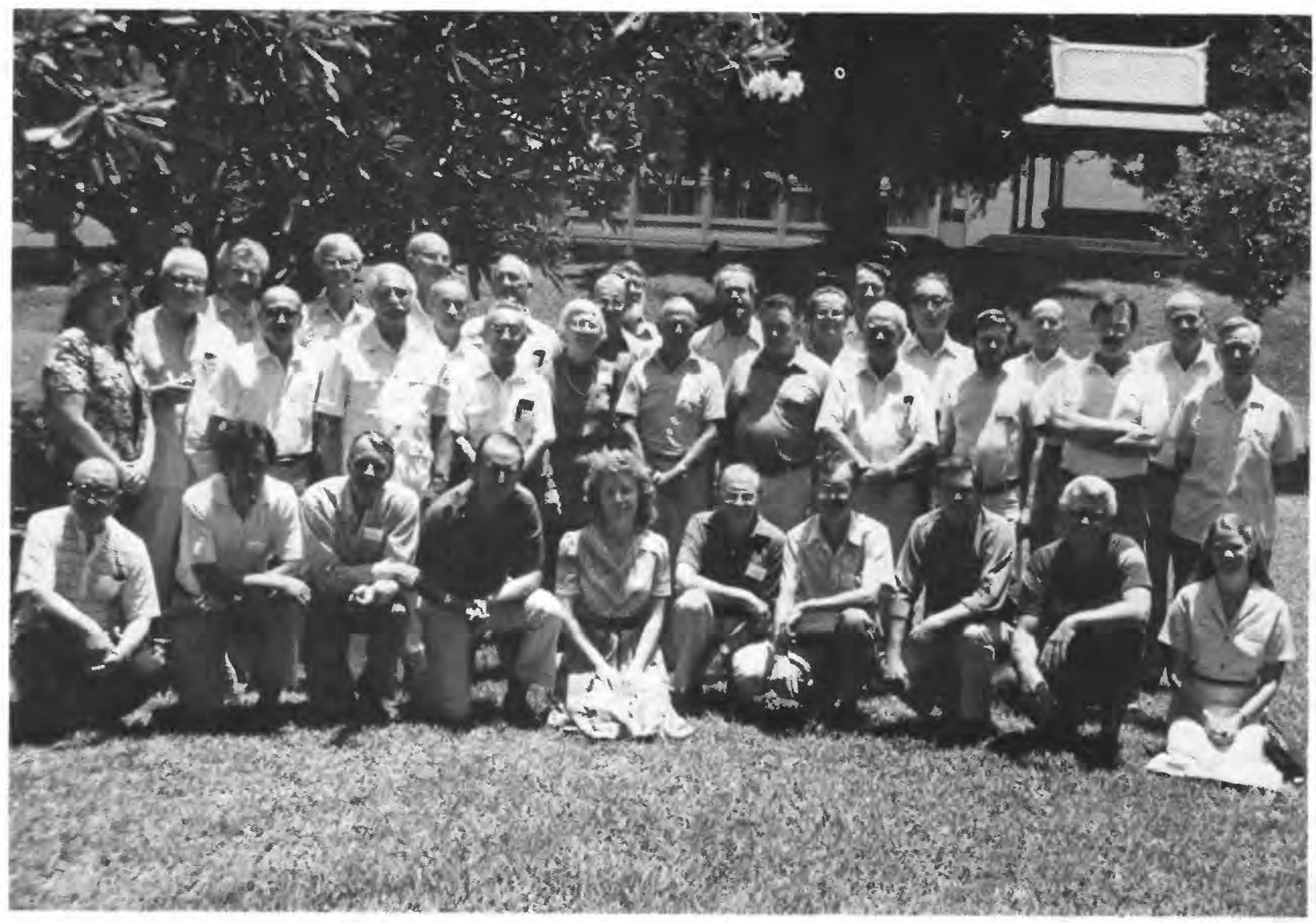

Figure 4. Participants in the 1983 Circum-Pacific Map Project Meeting, East-West Center, University of Hawaii, Honolulu, Hawaii. 


\section{ACKNOWLEDGEMENTS}

This report was prepared in large part from transcripts of tape recordings of the 1983 and 1984 Panel Chairmen's meetings in Honolulu, Hawaii, transcribed by Anne Gartner. The cooperation of members of the Map Committee in providing drafts of revised compilation guidelines and otherwise helping in the preparation of this report is acknowledged with appreciation. Photography is by Y. H.

Yang of the East-West Center, Honolulu, Turner Photographic of Honolulu, Lowell w. Kohnitz, Bradford Ito, and Warren O. Addicott. 
1984 PANEL CHAIRMEN'S MEETING

\section{INTRODUCTION}

The 11th Annual Meeting of the Circum-Pacific Map Project was opened by Map Project Director John A. Reinemund at $8: 30^{\circ} \mathrm{a} \cdot \mathrm{m}$. on June 4, 1984, at the East-West Center in Honolulu, Hawaii. Among the participants (figures 5 and 6; table 9) were Circum-Pacific Council Chairman Michel T. Halbouty and Council Directors from each of the quadrants of the Pacific. Outlining the goals for the three-day meeting, Reinemund called attention to the Project's relationship with other international mapping projects such as the Commission for the Geologic Map of the World (CGMW), and the Geologic Atlas of the Pacific and Atlantic Oceans (GAPA) of the Intergovernmental Oceanic Commission (IOC), as well as regional organizations such as the Committee for Coordination of offshore Joint Prospecting for Mineral Resources in Asian offshore Areas (CCOP). He noted that representatives from these organizations customarily meet with the Map Project each year.

Reviewing project activity since 1974, Reinemund declared that the Map Project could look back on a decade of expanding. scope and successful work. Initially the project was composed of only four panels and the projected number of map sheets was 16. Now with five regional panels and a 46-map schedule, the focus of effort is to complete the initial phase of work within the next $f$ ive years and also to explore and adopt new programs to be operated at the panel level. Goals of the originally-planned thematic maps are being met according to Reinemund. These are to depict and interrelate oceanic and continental geology and resources in a scheme flexible enough to accomodate new sources of data as they emerge. Further objectives are to adopt innovative mapping techniques and new methods of processing information (Reinemund, 1984a).

As the Project moves into its twelfth year, well over half of the planned map sheets are elther printed or in proof stage, Relnemund noted. Moreover, the panel structure has been strengthened as a consequence of instituting regularly scheduled meetings of the two eastern Pacific panels; the Northeast Quadrant Panel first met in November 1983 and the Southeast Quadrant Panel held its initial meeting in January 1984. Reinemund stated that a truly cooperative mechanism involving the countries of the Circum-Pacific region had been put into place. He underscored the progress made in developing a second phase of Project work involving resources-oriented mapping in specific regions. The first such sub-project of CPMP is the Southeast Asia Basin Evaluation Program initiated during the 1983-84 year.

Major issues facing the Map Project at the beginning of its second decade of work, according to the Project Director, are: (1) scheduling the completion of the thematic map series, (2) identifying additional thematic maps for the 1:17,000,000-scale total-area base, (3) determining available manpower and funding, (4) developing of a plan of action for the Southeast Asia subproject 


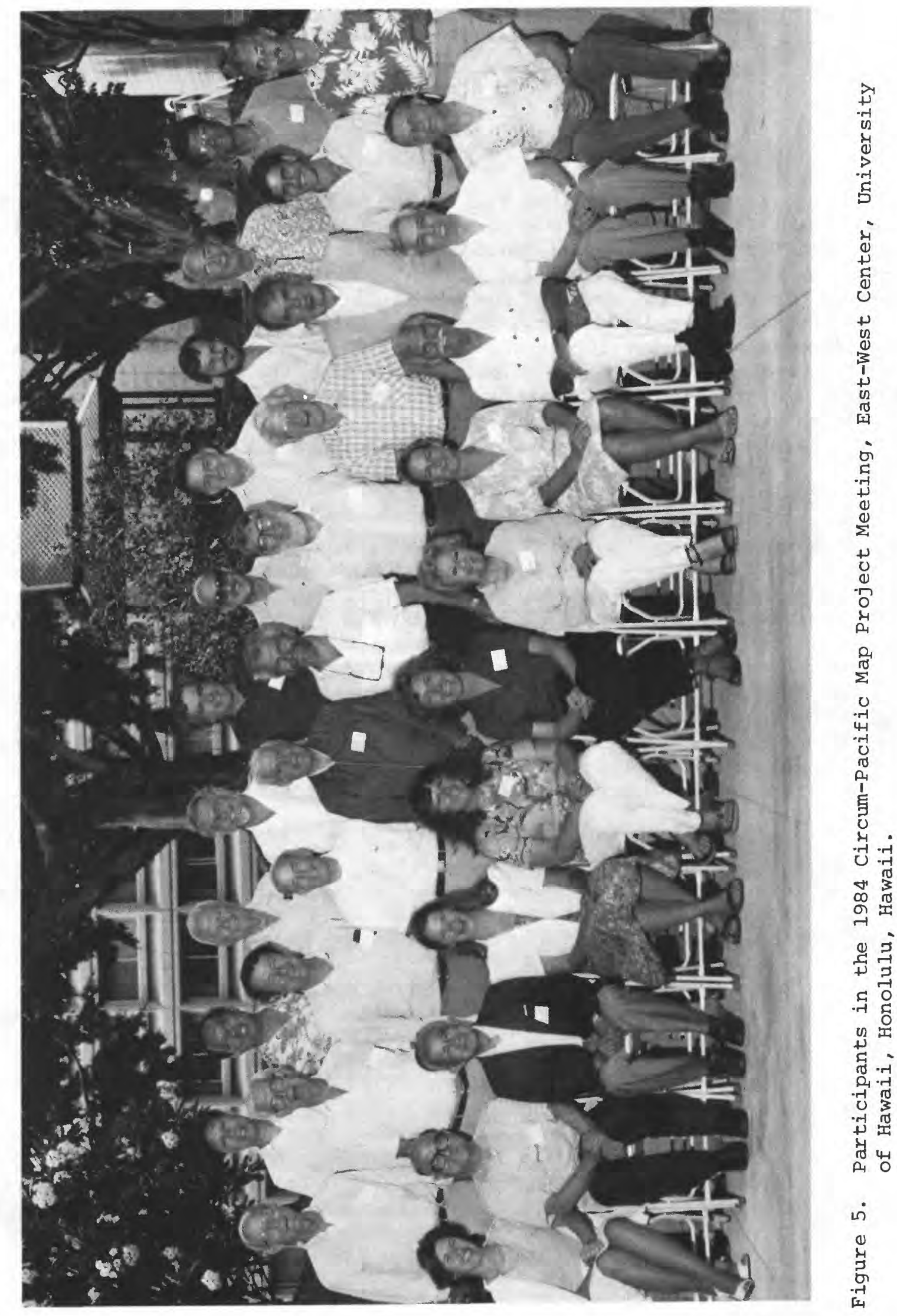


in cooperation with CCOP and the International Union of Geological Sciences (IUGS), and (5) identifying other regional sub-projects.

\section{CIRCUM-PACIFIC COUNCIL CHAIRMAN'S REPORT}

Circum-Pacific Council for Energy and Mineral Resources Chairman and President Michel T. Halbouty congratulated the panel chairmen and other Map Committee members on their products, noting the favorable acceptance of the Circum-Pacific maps worldwide. Council activities, according to Halbouty, were significantly expanded during 1983 and 1984. He cited the pole-to-pole cruise of the S. P. Lee, dubbed Operation Deep Sweep, which was cosponsored by the Circum-Pacific Council. Other Council-sponsored activities in 1984 included a workshop on forecasting volcanic eruptions and mitigating their effects held in Hilo, Hawaii, in June 1984, and a workshop on recent advances in petroleum exploration and development held in Beijing, China, in september 1984. Plans for the fourth quadrennial Circum-Pacific Conference scheduled for Singapore from August 17 to 22, 1986, are well advanced; a call for papers was issued in October 1984. Finally, Halbouty noted that the 694-page transactions volume of the 1982 Circum-Pacific Conference was published in 1984 and that the proceedings of the Council-sponsored Tectonostratigraphic Terrane Conference held in late 1983 will be the first number in the Council's new Earth Sciences Series. It was scheduled for printing in early 1985.

\section{GENERAL CHAIRMAN'S REPORT}

At the mid-1984 Panel Chairman's meeting, General Chairman warren 0 . Addicott declared that the past twelve months had been the most successful so far in terms of map production. Three maps had been printed since the last project meeting. Ten new color proofs had been completed for evaluation and study by the Map Committee in Honolulu during the second quarter of 1984. These formed the basis of a one-day review session on June 3. Newly perfected large-format color-copier technology aided in panel and map-element author reviews of color proofs this year. The efforts of project cartographers Frank J. Sidlauskas, Jr., and Frances R. Mills are to be especially commended in completing the proofs in time for the meeting.

Goals for 1984 and 1985 outlined were (1) publication of the six-map Geodynamic Series by the first half of 1985, (2) publication of the Geologic Maps of the Southeast, Southwest, and Northwest Quadrants by June 1985, (3) completion of a color proof of the Energy-Resources Map of the Northeast Quadrant, (4) completion of a proof of the Tectonic Map of the Southwest Quadrant, and (5) publicizing the newly printed maps.

Preliminary drawings for a new Map Project brochure, built along the lines of the late-1981 brochure, were presented together with a mockup of a one-page colored advertisement showing representative panels from each of the multi-colored published map series. Early 1985 has been set as the target for publishing these items. 


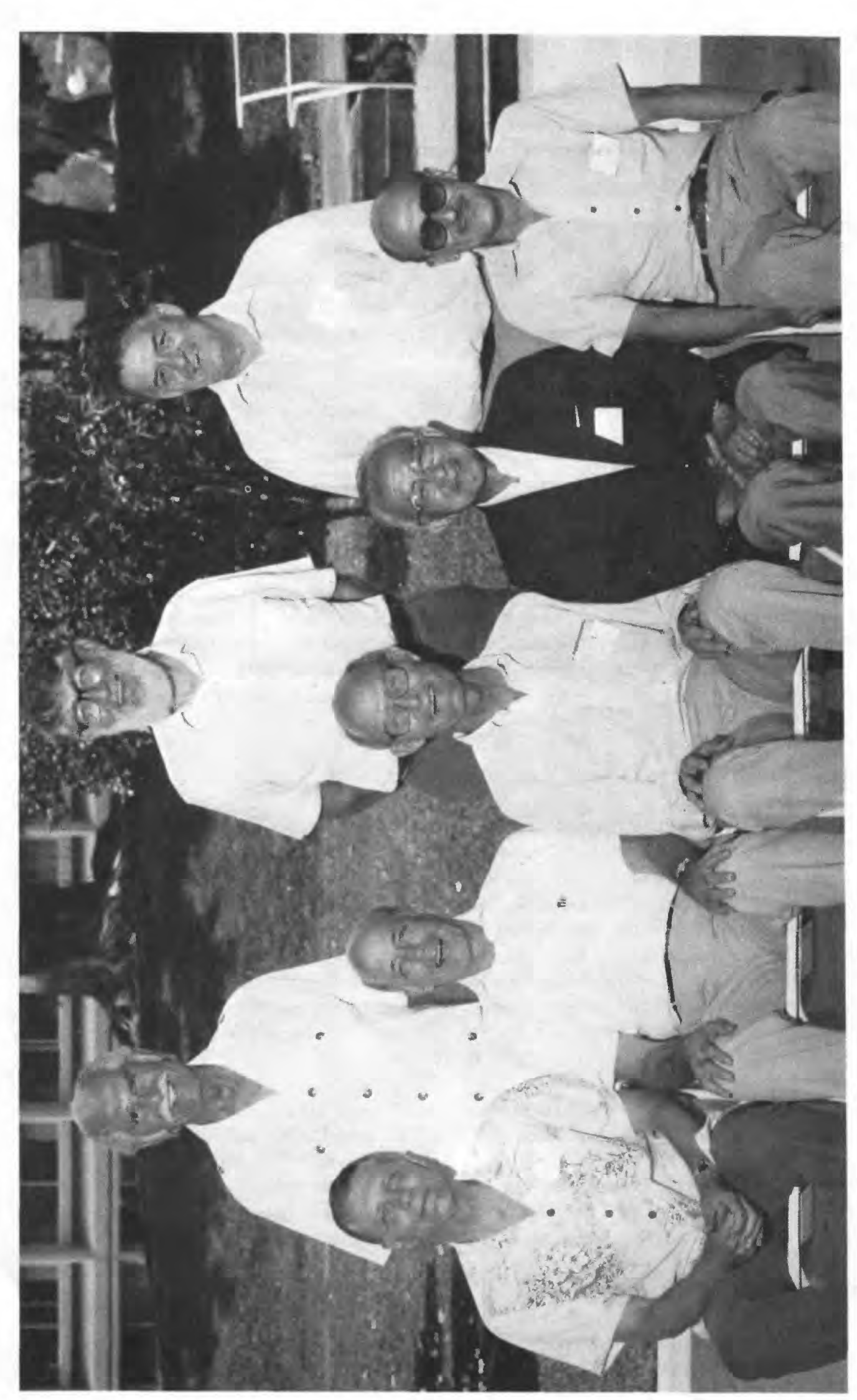

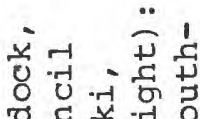

סृ 5 है

803

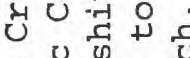

$\rightarrow-7$ -

可出嵌

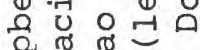

焉

Uी

..

겅

E E 质

का क्षे

牙昰

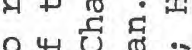

+ 0 동

से क्ष

(1) + द

$=0$ g 0 ठ o

मे $\rightarrow 0$ उ० \& 0 क न ह

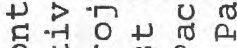
o t o o

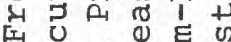
\& $x$ 西皆 舁之击

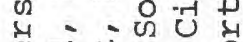
范 I 0.4 국

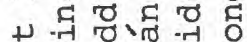
U (1).

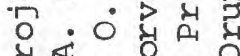
प्र

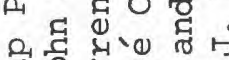

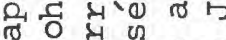

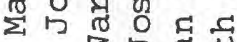
可.... तु प⿺

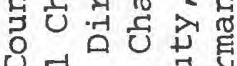
की + ह भौ ज्ञ तु कु मे क 讨西落

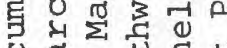
0

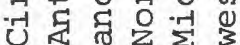

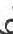

过 
Headquarters publicity during 1983 and 1984 included major exhibits of Circum-Pacific Maps at several national and international meetings, as well as informational articles in Episodes and the AAPG Explorer. Details are given in the section on map publicity.

\section{PANEL CHAIRMEN'S REPORTS.}

\section{Northwest Quadrant Panel}

Chairman Chikao Nishiwaki informed the 1984 Map Project meeting that compilations for the Northwest Quadrant Tectonic Map were received from the Soviet Union and from China during the first part of 1984. A target for completing this map in time for the fourth Circum-Pacific Conference in August 1986 was set at the Northwest Quadrant Panel Meeting held in Kuala Lumpur, Malaysia, in November 1983. Minutes from that meeting are included in table 10.

Significant progress in compilation of the two resources maps was also reported by Nishiwaki who noted that compilation of coal deposits for the Energy-Resources Map is completed.

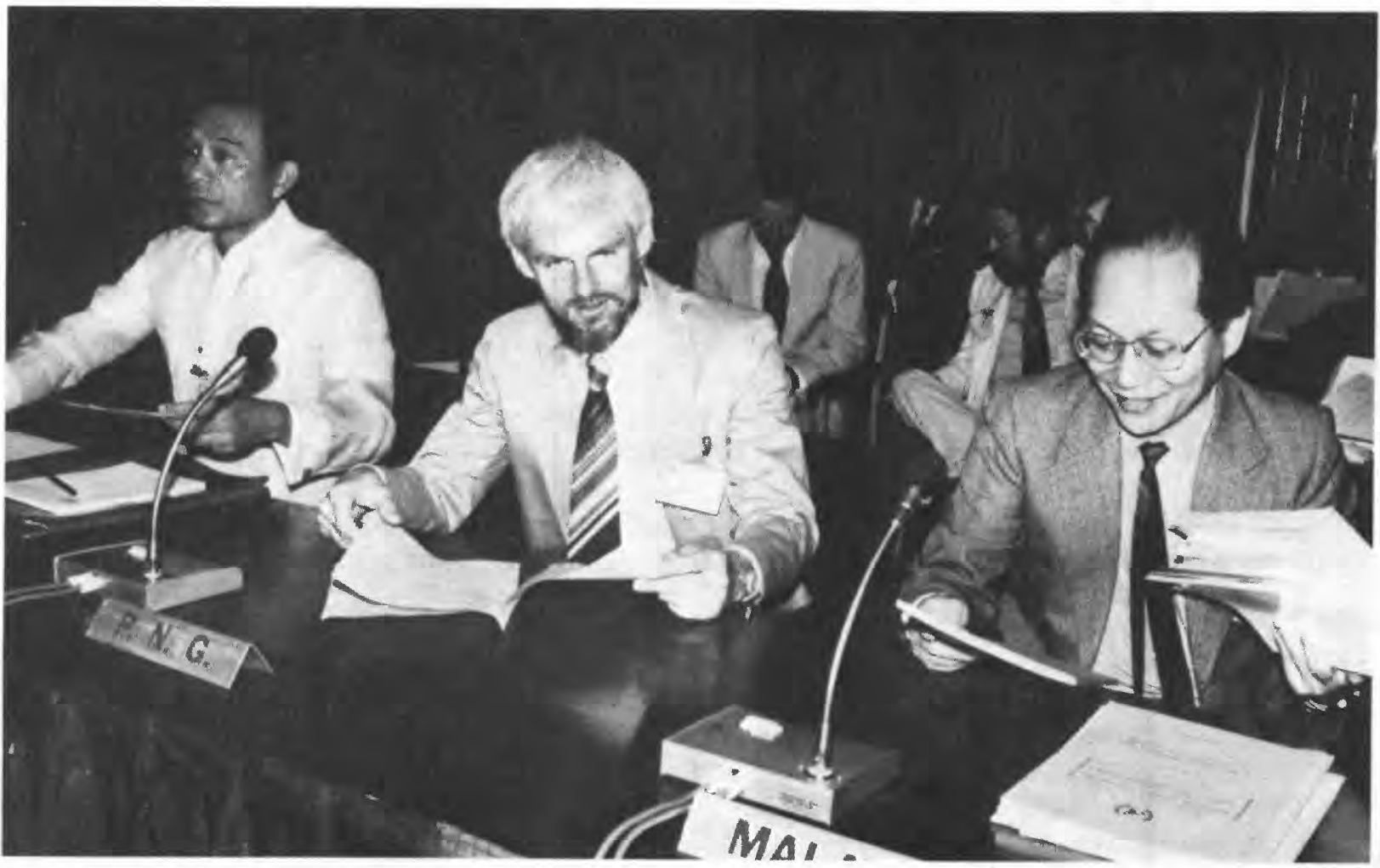

Figure 7. Northwest Quadrant Panel Meeting, Bandung, Indonesia, December 1984 (left to right) Juanito G. Fernandez, Philippines; Greg Anderson, Papua New Guinea; Yin Ee Heng, Malaysia. 
Nishiwaki announced that the Northwest Quadrant Panel had formally agreed to support the Southeast Asia basin-evaluation and resources assessment program at its 1983 meeting.

At the December 1984 meeting of the Northwest Quadrant Panel (figure 7), held in conjunction with the XXI meeting of the Committee for the coordination of Joint Prospecting for Mineral Resources in Asian Offshore Areas (CCOP) in Bandung, Indonesia, country representatives reaffirmed their support of the program. Notes from the meeting are included in table 11.

\section{Antarctica Panel}

Campbell Craddock, Antarctica Panel Chairman, said that the major effort by his panel to date had been on compiling the Geologic Map. Mineral deposit data for Antarctica was compiled by Philip Guild and Michael Lee during 1984. The next map sheet to be completed will be the Tectonic Map.

A meeting of the Antarctica Panel was held at the International Geological Congress in Moscow in August 1984 (table 12).

\section{Southwest Quadrant Panel}

Chairman H. Frederick Doutch noted that there had been a substantial advance in compilation of the Southwest quadrant maps during the year ending in June 1984. Increasing numbers of geoscientists are becoming involved with either the basic map compilations or review of map manuscripts or color proofs, according to Doutch. The Panel met in Lamis, Fiji, in October 1983 (table 13) and in Apia, Samoa, in October 1984 (figure 8).

A newly completed color proof of the Geologic Map of the Southwest Quadrant was displayed at the 1984 Panel Chairmen's meeting, and Doutch reported that preparation of the explanatory notes manuscript was well advanced. Particular effort during 1983 and 1984 was focused on the Tectonic Map of the Southwest Quadrant which was completed by Erwin Scheibner and submitted for cartography during september 1984. Progress had also been registered on the Mineral-Resources and Energy-Resources Map compilations.

A major problem in the Southwest Quadrant region, according to Doutch, is publicizing the work of the Circum-Pacific Map Project and the available publications. Panel members have expressed great interest in the computerized mapping techniques that are being utilized in the cartographic preparation of the Geologic Map Series. The Panel Chairman asked that the Map Project, or the Circum-Pacific Council, provide further information on these new cartographic methods. 


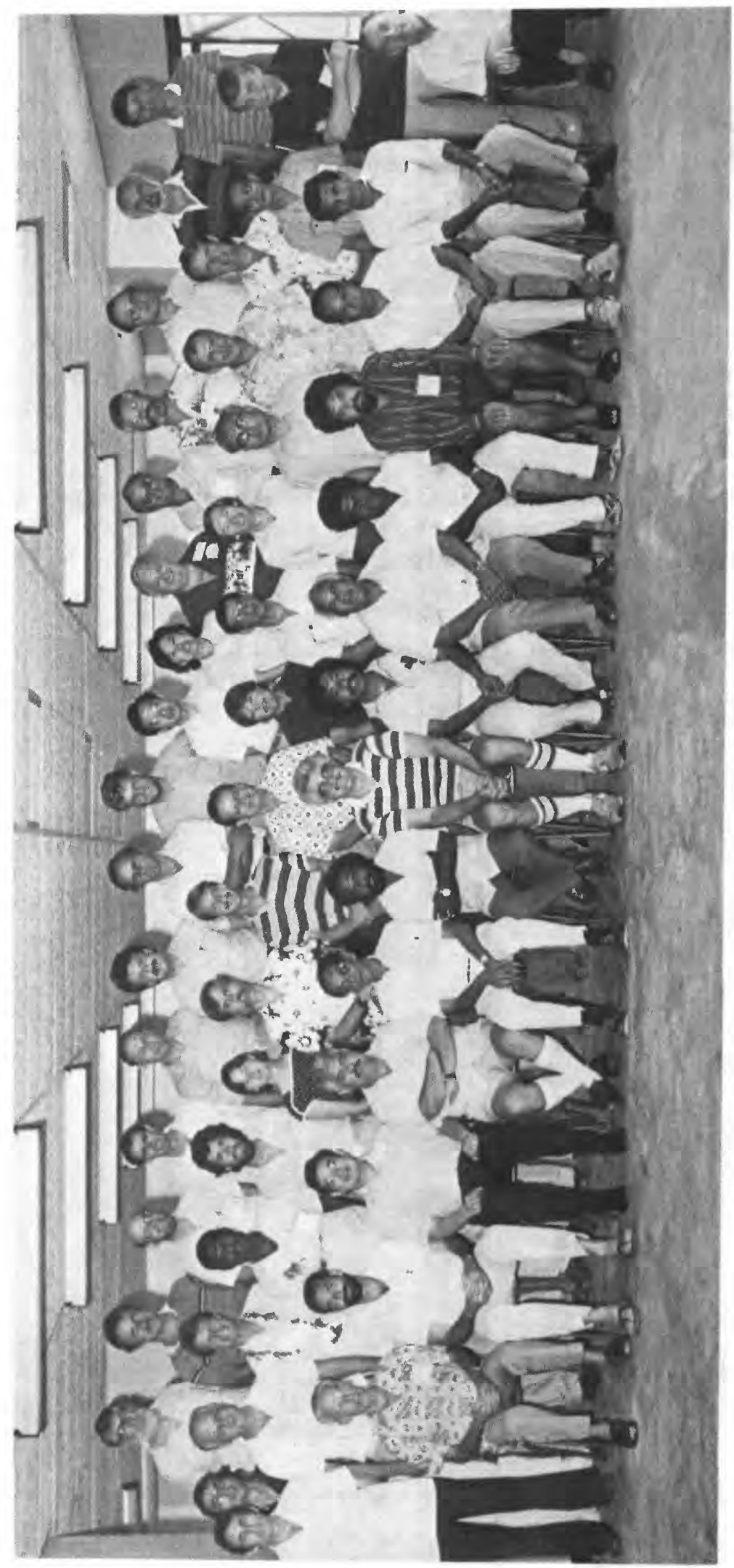

$n$
0
0
3
3
1
0
0
0
0

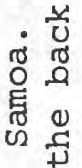

गु 4

还+

-i

o

ก

$+4$

o

造

ว

u

\&

प्山ि

马

it

ब)

E .

ए

बำ

4 不

贾

$+5$

응

站

U

ज

U)

कि

on

- 0 c

붕

공

ณ

$\dot{\infty}$

. 
Southeast Quadrant Panel

Compilation efforts during 1983 and 1984 were directed principally toward the Geologic Map according to Panel Chairman José Corvalán D. of Chile. Final revision of this map was completed during the first part of 1984 following panel review of the color proof in January. The bilingual Spanish and English text for the explanatory notes, which will accompany this map, was completed and checked by Corvalán who declared that it was ready for printing.

Work on the two resources maps was well advanced, according to Corvalán, who said that the Mineral-Resources Map was closest to completion. The text for the explanatory notes for this map sheet will be a principal focus of effort during 1985 .

Several new members were added to the Southeast Quadrant Panel during 1983 and 1984 (table 4). One of the new members, Marcelo Yrigoyen of Argentina, agreed to take over principal coordination of the Energy-Resources Map.

Corvalán announced that the initial meeting of the Southeast Quadrant Panel (figure 9), held in Santiago during January 1984, was attended by nearly 40 people, including a number of Chilean geoscientists who, as a result of

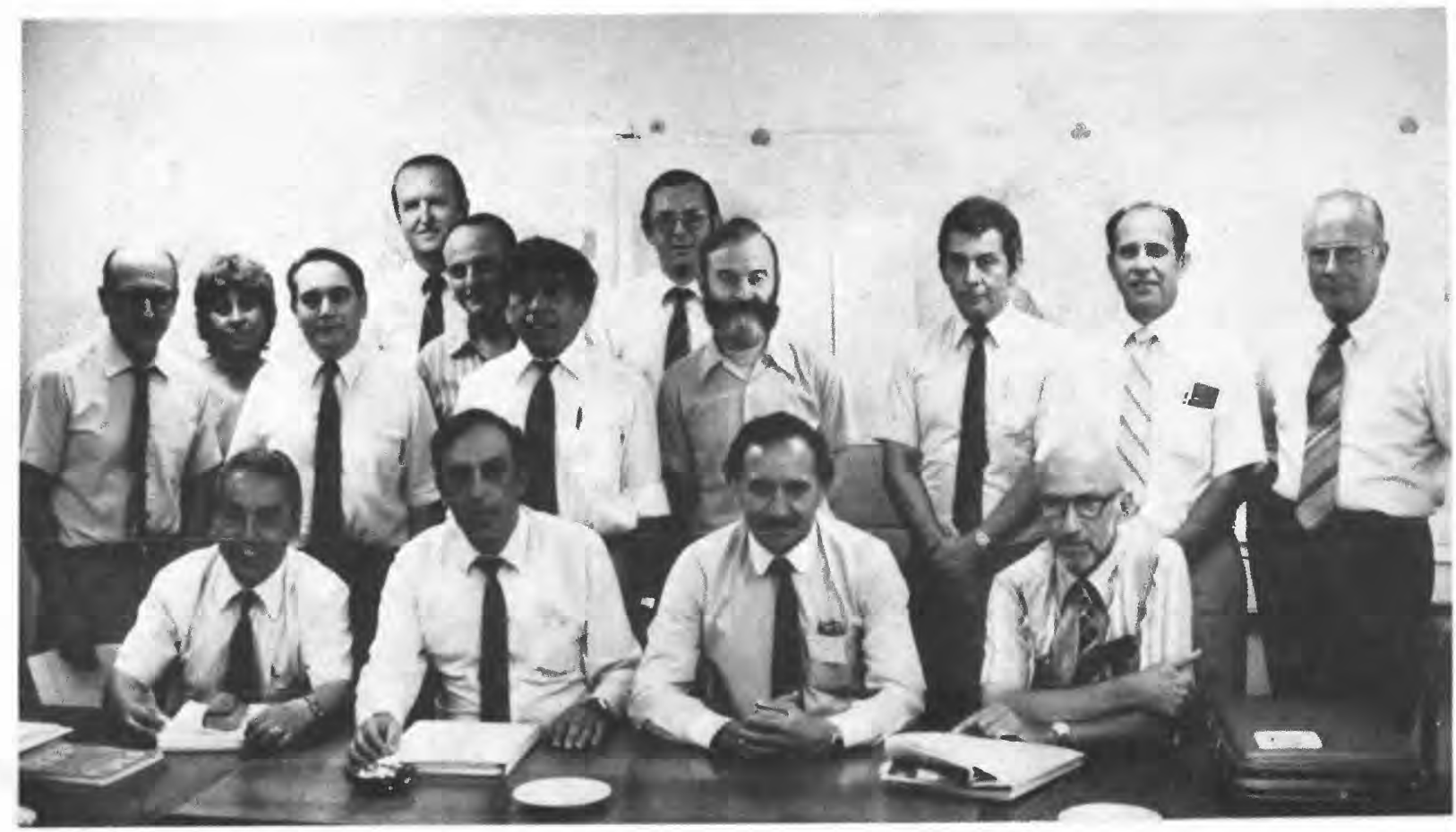

Figure 9. Participants in the Southeast Quadrant Panel meeting, Santiago, Chile, January 1984 . 
this meeting, became actively involved in the panel's work. A report of this meeting is included as table 14. Circum-Pacific Council support of this meeting was acknowledged and plans were laid for a meeting in March 1985, in Lima, Peru, which will be facilitated by Victor R. Eyzaguirre P.

\section{Northeast Quadrant Panel}

Chairman Kenneth $\mathrm{J}$. Drummond of Canada reported that the first meeting of the Northeast Quadrant Panel was held in Indianapolis, Indiana, in November 1983 (figure 10) with representatives from four North American countries participating. A major item of business was the identification of new members from Central American countries. Gabriel Dengo of Guatemala provided names of several potential candidates. A major effort was made during 1984 to bring new members from all Central American countries into the panel. A fullmembership meeting was scheduled to be held in Mexico City in February 1985 in cooperation with Mexican panel member Guillermo P. Salas and the CircumPacific Council. A report from the 1983 panel meeting is included in table 15.

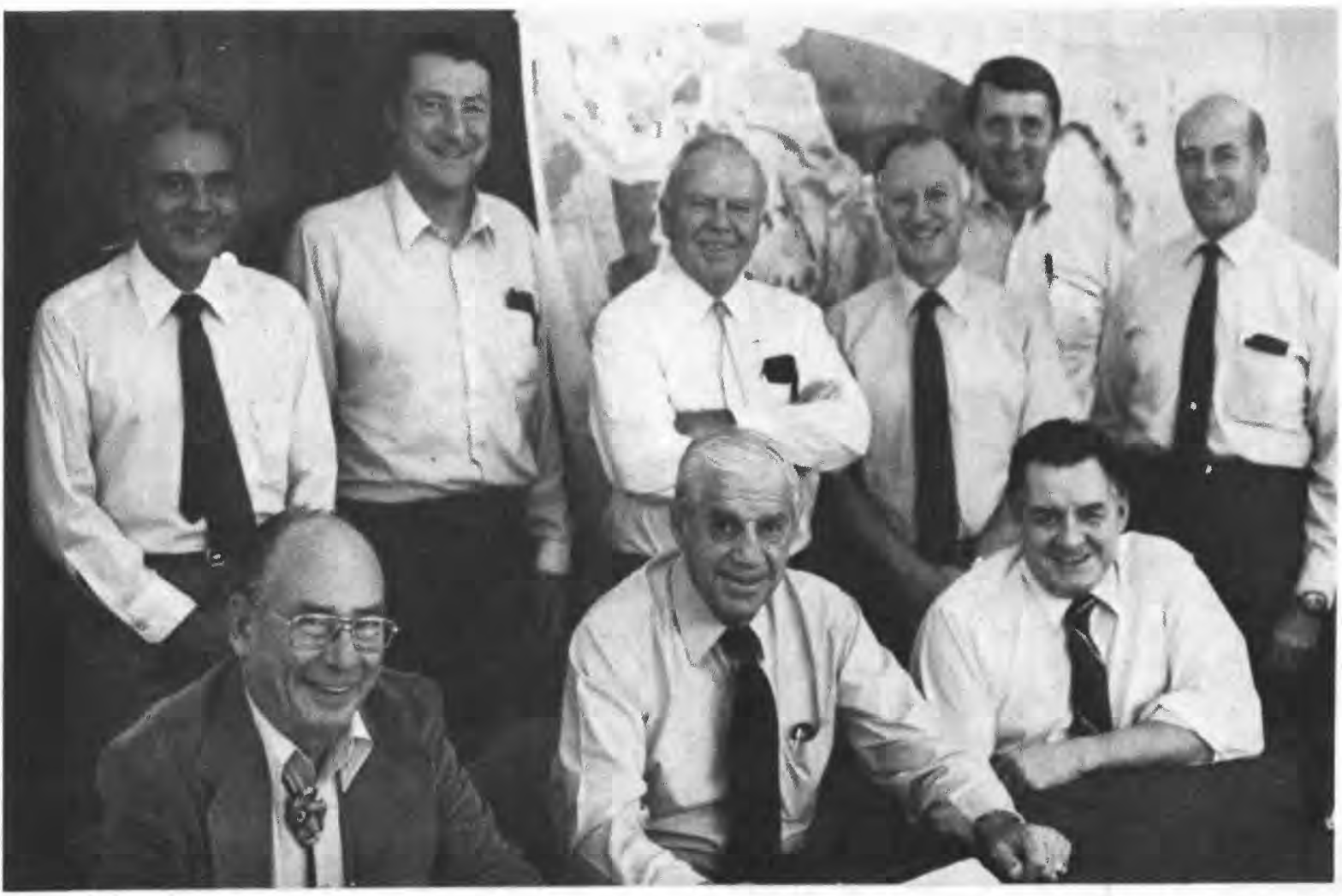

Figure 10. Participants in the Northeast Quadrant Panel meeting, Indianapolis, Indiana, November 1983. 
A report by Ronald L. Hart, Projects Manager for the American Association of Petroleum Geologists (AAPG), was presented to the meeting by the Map Project General Chairman. During 1983 and 1984, the AAPG Bookstore, sales agent for the Circum-Pacific Maps, experienced lower sales than previously in every category (table 16), according to Hart, who attributed the slowness to market saturation. An upswing in sales as each new series is completed and advertised was predicted.

AAPG policy continues to be to wait until an entire series of maps is available for sale before advertising that series, although individual map sheets will be sold as they become available. Starting with the Geologic Map Series in late 1983, all new map sheets will be folded, although a small supply of rolled maps will be furnished to project headquarters for distribution to authors and project participants. Map Committee members questioned AAPG's policy of waiting to advertise the maps until each series is completed. Addicott pointed out the sales potential of the individual North American maps as separate items, noting that a considerable amount of time will occur between publication of the first and last sheets in some series. Halbouty recommended that a formal request be made to AAPG to change this policy and publicize maps as they are published.

Hart's sales report indicated that the publisher is negotiating with sales agencies in Canada, Australia, and continental Europe to serve as distributors for the Circum-Pacific Maps and other AAPG publications. Discussions with potential outlets in Japan and Singapore have not as yet led to sales agreements.

\section{MAP PUBLICITY}

At the June 1984 Panel Chairmen's meeting, Circum-Pacific Council Chairman Michel $T$. Halbouty recommended that the Map Committee take steps to increase publicity of the published Circum-Pacific Maps. It was specifically recommended that as each new map is printed, headquarters develop a brief informational manuscript article and make these manuscripts avallable to the regional panels for translating and printing in appropriate Pacific-region journals. This would complement the 43,000-copy distribution through the map publisher, AAPG. Continued publicizing of new maps and Map Project activities through the AAPG Explorer, a primarily North American geological news magazine, was also commended to the Map Committee.

Several Map Committee members, including Campbel1 Craddock, argued that publicity for the 1:17,000,000-scale Plate-Tectonic Map of the Pacific Basin should be intensified. It was judged an especially useful aid in teaching, and the fact that the map is still not well known in the profession was stressed. The desirability of designating someone as an informational specialist to disseminate news about the maps was brought up by Doutch. 
The Committee's attention was called to a favorable review of the Plate-Tectonic Map Series by Harper (1983).

At the June 14 and 15 meeting of the Circum-Pacific Council for Energy and Mineral Resources, also in Honolulu, the Council Directors authorized revision and reprinting of the 1981 Map project brochure. Reprinting is scheduled for the first half of 1985. The Council also authorized printing and distribution of a one-page announcement of new Circum-Pacific thematic maps. A preliminary layout calls for full-color panels of sample areas of five map series together with a listing on the reverse side of available maps and ordering information. Printing is scheduled for early 1985.

Major exhibits of printed Circum-Pacific Maps were presented at the International Geological Congress in Moscow during August, the American Association of Petroleum Geologists Meeting in San Antonio in May, and the Geological Society of America Annual Meeting in Reno, Nevada, in November. The focal point of these exhibits was a two meter raised-rellef map of the

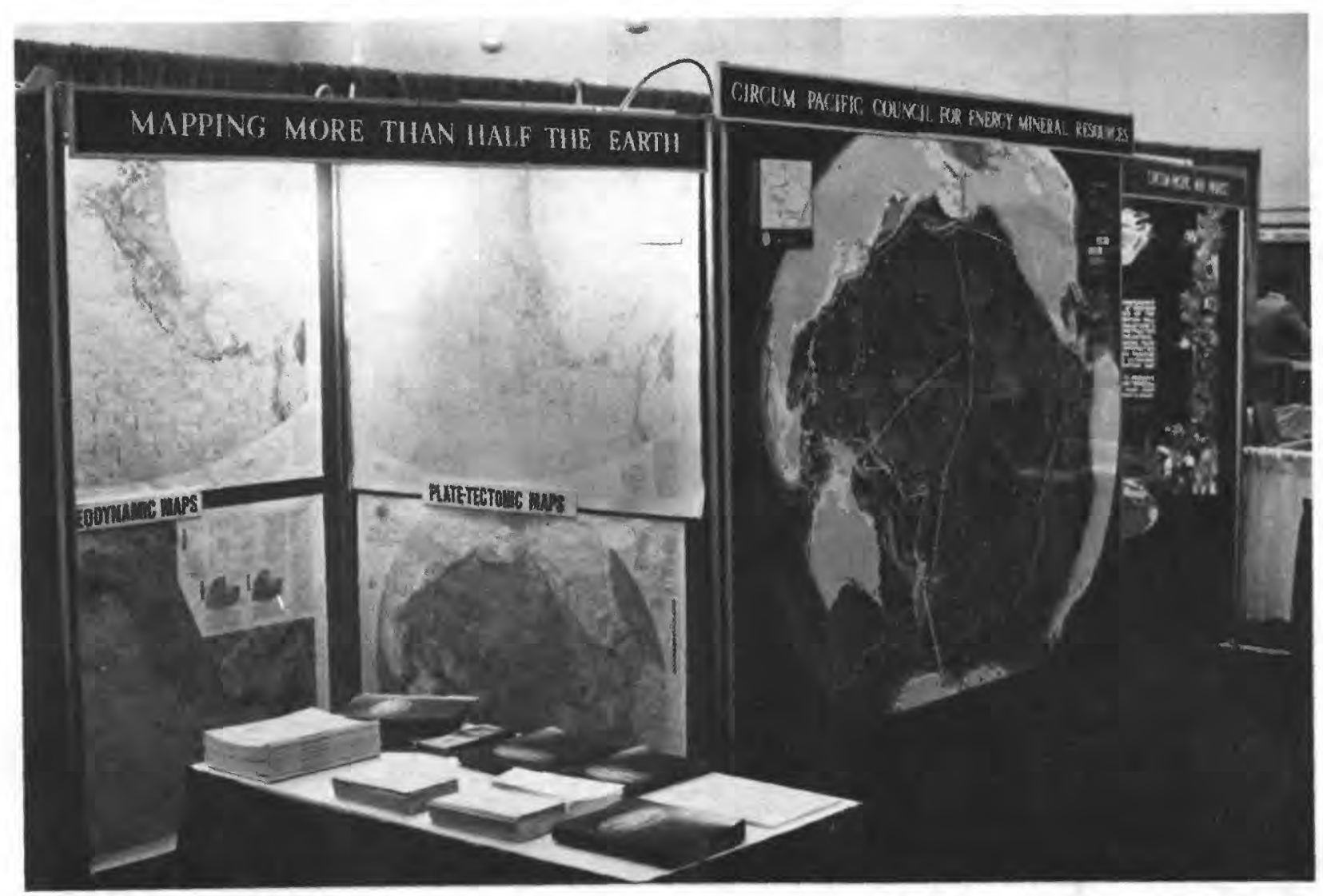

Figure 11. Circum-Pacific exhibit at the Geological Society of America Annual Meeting, Reno, Nevada, November 1984. 
Pacific Basin depicting plate-tectonic features. This exhibit depicts the active and Holocene volcanoes of the Pacific Region by colored fibre optics (figure 11); also shown are active plates, plate motion vectors, magnetic lineations, fracture zones, and selected hotspots. The display was developed by Walter C. Black, Exhibits Chairman of the 1982 Circum-Pacific Conference.

Other map exhibits were presented at regional conferences and meetings, including the Australian Geological Congress, the XXI Meeting of the Coordinating Committee for offshore Mineral Prospecting in Southeast Asia, and the Argentinian Geological Congress.

\section{GEOLOGIC MAP SERIES}

Overview

Publication of the Geologic Map series, initiated during the last half of 1983, is scheduled to be completed during 1985. The Geologic Map of the Northeast Quadrant, the pilot sheet of the series, was printed in November 1983 (Drummond, 1983). The companion explanatory notes, a 35-page bilingual documentary booklet in English and Spanish, was issued early in the following year (Drummond and others, 1984a).

At the June 1984 Panel Chairmen's meeting, discussion chairman George W. Moore observed that considerable progress toward completing this series had been made during 1983 and 1984. Instrumental in this progress has been the use of state-of-the-art computer technology in generating map-unit colors and lithologic patterns. This technique, which was initiated in the Geologic Map Series through the use of a contractor, simplifies and accelerates map cartography and has provided an effective means of correcting and adding new data to the maps. Staff cartographer Frances Mills received specialized training in computerized generation and editing of color plates during November 1984 and by year end was making corrections and additions to the Geologic Maps of the Southeast and Southwest Quadrants using a computerized edit station in Menlo Park, California.

\section{Northwest Quadrant}

The first color proof of the Geologic Map of the Northwest Quadrant, completed during May 1984, was presented to the 1984 meeting by Panel Chairman Nishiwaki. He pointed out a problem created by the differing depiction of ultramafic rocks by the Northwest and southwest Quadrant panels. This map unit is depicted in black on the Northwest Map compilation and in colors according to age with a lined overprint on the Southwest Map. A sizeable overlap area--lat $10^{\circ} \mathrm{S}$. to lat $16^{\circ} \mathrm{N} .--$ is shared by the two map sheets; the Northwest Quadrant is responsible for compilation of the overlap area west of long $130^{\circ} \mathrm{E}$. and the Southwest Quadrant for the area to the east. Rather than to have two unit designations on these maps, Tadashi sato, co-compiler 
of the Geologic Map of the Northwest Quadrant, agreed to furnish geologic ages for ultramafic units in the western part of the overlap for the Southwest Quadrant Map, and it was decided that all ultramafics on the Northwest Map will be depicted in black.

Nishiwaki also noted that new drafts of mainland Asia for the Tectonic Map, received from China and from the Soviet Union during the first half of 1984, may require extensive modification of units on the Geologic Map of the Northwest Quadrant to make them compatible with the Map Project format. Work on the explanatory notes manuscript for the Northwest Geologic Map was targeted for completion by the end of 1984 .

\section{Southeast Quadrant}

Final corrections for the second color proof of the Southeast Quadrant Map were received from the panel members during 1983 and 1984 . Chairman José Corvalán recommended that the date of the final compilation be placed on this map as an explanation of the cutoff date for newly published map information. In the case of the Southeast Geologic Map, which has taken two years to correct and bring into final form, he pointed out that it had not been possible to incorporate recently published geologic mapping in Chile and Argentina.

At year-end 1984, final cartographic corrections were being made on this map, and publication was scheduled for the first quarter of 1985 .

\section{Southwest Quadrant}

An initial color proof of the Southwest Quadrant Geologic Map was also completed during May 1984. Panel Chairman H. F. Doutch advised the Map Committee that three especially significant new maps of the Southwest Pacific region recently received by him would necessitate updating the proof during the checking stage. Further checking and refinement of the overlap region with the Northwest Quadrant is also required, in particular the ultramafic units in Southeast Asia already referred to. Doutch acknowledged that the use of color with a heavily patterned overprint to designate the age of ultramafic units on the Southwest Quadrant Map departed from usage on the other Geologic Map sheets. He also observed that the format for the expanded unit descriptions in the explanatory notes manuscript will be on a country-bycountry basis for the Southwest Quadrant.

\section{Antarctica Region}

Panel Chairman Campbell Craddock reported that the Geologic Map of Antarctica, compiled during 1982 and 1983, was awaiting completion of the new Antarctica base map in Reston and subsequent cartography in Menlo Park. Owing to the fact that substantial parts of the Southwest and Southeast 
Quadrant appear on the Antarctica sheet, publication of the Antarctica Geologic Map must necessarily follow the other southern sheets. Nevertheless, parts of the Antarctica continent appear on both the Southwest and Southeast Quadrant sheets and the Antarctica Region Panel has been actively involved in contributing to those sheets. Some updating of Craddock's 1982 and 1983 compilation may be required once the Antarctica map is in proof. Work on the explanatory notes manuscript will be delayed until the first color proof is in hand.

\section{Pacific Basin Map}

Vincent E. McKelvey recommended that a $1: 17,000,000$-scale map of the Pacific Basin be included in the Geologic Map Series, noting that some geologic features can best be brought out at that scale. Moore observed that to do this a principal compiler would need to be identified and would have to work closely with the Panel Chairmen in generalizing the information. A particular problem would be merging the different map legends used by the five regional panels for land geologic units. Further discussion was held during the session on Pacific Basin maps, which is summarized in a later session.

\section{Summary and Plan}

Addicott complimented the Panel Chairmen and the cartographic staff for progress made on the Geologic Map Series during the year. A target of completing the entire series of $1: 10,000,000$-scale maps during 1985 was agreed upon. In response to a suggestion by Craddock, seconded by Corvalán, it was further agreed that the explanatory notes for the Antarctica Sheet be printed in both English and Spanish. The Southeast Quadrant Panel of fered to provide the Spanish translation of the text for the document.

\section{PLATE-TECTONIC MAP SERIES}

A revised edition of the 1:17,000,000-scale Plate-Tectonic Map of the Pacific Basin was printed during the first half of 1984. This was the second reprinting of this popular map, which was originally issued in 1982. Principal revisions to the map, according to George W. Moore, Project Coordinator for Marine Geology and Resources, include fracture zones and the addition of magnetic anomalies in the high latitudes of the South Pacific. Moore pointed out that information from SEASAT surveys allowed corrections in the alignment of some of the fracture zones. Many of these minor changes were also incorporated in the revised second printing of the 1:10,000,000-scale PlateTectonic Map of Antarctica, issued in 1983.

\section{GEOGRAPHIC MAP SERIES}

Revision of the 1:10,000,000-scale base map of the Antarctica Region was 90 percent completed at the time of the Map Committee meeting in June 1984, 
according to Map Project cartographer Frank J. Sidlauskas, Jr. The shoreline of Antarctica was revised from information compiled by Drewry (1984). Revision of the base map was necessitated by the discovery that an incorrect center point of lat $20^{\circ} \mathrm{S} .$, long $165^{\circ} \mathrm{W}$. had been used in preparing the original base map, resulting in a distorted outline of the Antarctica continent and departure from the intended map scale. The remaining thematic maps of Antarctica-Geologic, Geodynamic, Mineral-Resources, and Tectonic will be issued on the new base.

A color proof of the new Antarctica base was scheduled to be completed during January 1985.

Craddock commended the work done on the new base map, observing that the portrayal of Antarctica is much improved. The new data utilized in drawing the shoreline and surface contours have added greatly to the value of the map according to Craddock. He recommended that the map publisher print revised map sheets in both the Geographic and Base Map series. Inclusion of a substantial part of the Australian continent on the new base will make the map liseful as a possible vehicle for representing tectonostratigraphic terranes and Gondwanaland history, according to Doutch.

A decision on reprinting the Geographic Map and Base Map of Antarctica was carried over to the 1985 Panel Chairmen's meeting.

\section{MINERAL-RESOURCES MAP SERIES}

Overview

Publication of the Mineral-Resources Map Series began in late 1984 with printing of the Northeast Quadrant Map on December 12, 1984 (Drummond, 1984b). Significant progress in compilation of mineral-deposit data and geologic background for the other map sheets was reported by each panel at the mid1984 Panel Chairmen's Meeting. Color proofs of the marine minerals element for the Northwest and Southeast Quadrant Maps were completed during May 1984. Compilation of the manganese-nodule abundance data and seafloor sediment distributional patterns from the Geologic Map series onto the $1: 17,000,000-$ scale pacific Basin sheet was completed during February 1984; a color proof of this map was made in May.

\section{Northeast Quadrant}

At the June 1984 Panel Chairmen's meeting, Mineral-Resources Map Advisor Philip w. Guild reviewed the sequence of color proofs of the Northeast Quadrant Map, noting that the May 1984 proof was preceded by proofs made in 1982 and 1983. Perfecting the geologic-tectonic background for this map was complicated by the concomitant cartographic preparation of the Northeast Geologic Map, from which the background was derived. Guild noted that the geologic-tectonic 
background units adopted for the Northeast Quadrant would not necessarily be required for other map sheets in the series.

Only minor changes were required in the contouring of manganese nodules on the Northeast Quadrant Map during 1984, according to David Z. Piper. The problem of overprinting of colored crosses denoting chemical analyses of manganese nodules on black crosses denoting cores that recovered manganese nodules was discussed by Guild. On Piper's recommendation, it was decided, not to thin either of the two data sets in view of the more intense symbol colors that were expected on the finally printed map.

\section{Northwest Quadrant}

Panel Chairman Chikao Nishiwaki reported that transferring of mineral deposit information from a 1:5,000,000-scale map compilation to the CircumPacific base was in an advanced stage in mid-1984. Use was being made of a 1:10,000,000-scale map of the ore belt along the Pacific for the coastal part of the Soviet Union (Radkevich, 1979). Mineral-deposit information for the inland part of the Soviet Union and for China, however, were not available. Late in the year, Dr. Pow Foong Fan of the University of Hawaif agreed to assist the Northwest Panel in compilation of mineral-deposit information for China. And in August 1984, Deputy Panel Chairman Tamotsu Nozawa completed arrangements for compilation of mineral-deposit information for interior parts of the Soviet Union not included in Radkevich's 1979 map. The target for completing compilation of mineral deposit data was set for year-end 1984 .

The Northwest Quadrant's compilation of background geology for their Mineral-Resources Map was presented at the Honolulu meeting in June 1984. Corvalán observed that this depiction was based entirely on geologic age and that it was a departure from the compilation guidelines developed for the Northeast Quadrant (U.S. Geological Survey, 1983). He pointed out that the guidelines were for lithogenic units and carry little or no age connotation. Guild observed that geologic-unit boundaries and letter symbols denoting age of geologic units that appear on the Northeast Mineral-Resources Map were taken directly from the Geologic Map Series; these, he said, permit determination of geologic age for much of the background on the Mineral-Resources Map of the Northeast Quadrant. An ad hoc committee, convened on June 13, 1984, to resolve the questions of uniformity of geologic background for the five sheets in the Mineral-Resources Map Series, concluded that departure from the guidelines was acceptable where necessary. A summary of this meeting is included in a following section.

It was announced that the Northwest Quadrant is also planning to depict some features from the Plate-Tectonic Map on the Mineral-Resources Map.

A color proof of the marine-minerals element of the Northwest Quadrant was completed during May 1984. The proof was displayed at the Panel Chairmen's meeting and also at the Northwest Quadrant Panel Meeting in December 1984. 
This map served as the basis for compilation of the northwest part of the Pacific Basin Manganese Nodule, Seafloor Sediment, and Sedimentation-Rate Map scheduled for publication during the first half of 1985 .

\section{Southwest Quadrant}

Compilation of the Southwest Quadrant Map was still in a preliminary stage in 1984. The geologic background combines three basic age units-Phanerozoic, Proterozoic, and Archaean--with a variety of rock environments. Cartographic emphasis, according to Panel Chairman Doutch, should be directed toward depicting the rock type, with secondary emphasis on geologic age, which could be shown either by letter symbol, as on the Northeast Quadrant Map, or by adding gray screens of increasing intensity for Proterozoic and Archaean units to the colors used to denote rock type. It is not yet clear how these can be merged with the much larger number of age units that are being used on the Northwest Quadrant Map. A proposal to revise the deposittype classification of the Northeast Quadrant Map (Drummond, 1984b) to better classify Australian mineral deposits was made in September by Rosalyn Chan, co-compiler of the Southwest Map with David Palfreyman. Chan also proposed revising the format for depicting the age of mineralization (Guild, in Addicott, 1980, p. 56) so as to provide a classification more appropriate for Australia (table 17).

\section{Southeast Quadrant}

The compilation for the Mineral-Resources Map of the Southeast Quadrant was completed during 1983 and, as of late 1984, was being reviewed and revised by representatives of the Andean countries. Copies of the map were made available to panel members at the January 1984 Southeast Quadrant Panel meeting held in Santiago. Chairman Corvalán said that the geologic background was simplified from the Geologic Map of the Southeast Quadrant and follows, rather closely, the scheme developed by Guild for the Northeast Quadrant Map.

McKelvey observed that the Southeast Map would likely be the second sheet in the series to be published and that it would conform quite closely to the format of the Northeast Quadrant, the sheet with which it shares a substantial overlap.

Compilation of the marine-minerals element--manganese nodule occurrence and chemistry, phosphorite occurrence, massive sulfide deposits, and marine placers-for the Southeast Quadrant was completed by David Z. Piper and Theresa Swint in late 1983. A color proof was made in May 1984 and was in review by the Southeast Quadrant Panel at year-end 1984 . 


\section{Antarctica Region}

Compilation of mineral-deposit data for Antarctica was completed in late 1983 by Philip Guild and Michael Lee. Chairman Campbell Craddock declared that the original units on the Geologic Map would likely be combined into five or six units following the kinds of categories established for the Northeast Map. He supported uniformity of guidelines throughout the five map areas in this regard.

\section{Geologic Background for the Series}

Extended discussion of the compilation guidelines for background geology was occasioned by the Northwest Quadrant's proposal to use age rather than rock type for the map background. It was recognized that there is such minimal overlap of land areas between the eastern and western quadrants that no problems would be encountered if the Northwest Map carried a background different from the Northeast Quadrant Map. David Piper pointed out, however, that the new Antarctica Base Map includes substantial portions of Australia and South America. Accordingly, uniformity of geologic background between the southern quadrants and Antarctica is essential. Doutch said that the Southwest Quadrant Panel was flexible with regard to depicting geologic background but that further differentiation of Proterozoic and Archaean should be carried out. McKelvey pointed out that if two kinds of geologic background are used on the various quadrant maps the problem of uniformity would simply be transferred to the Pacific Basin Mineral-Resources Map, if such a map was added to the map series.

The problem was carried over to the final day of the Panel Chairmen's meeting with the appointment of an ad hoc committee to resolve the question of uniformity of geologic background for the Mineral-Resources Map Series. The committee concluded that departure from the legend developed for the Northeast Quadrant was warranted and it approved the use of geologic age as the principal criterion for unit designation and coloration on the MineralResources Map of the Northwest Quadrant.

\section{Manganese Crusts}

McKelvey commented upon the lack of distinction between cobalt-rich manganese crusts and cobalt-rich nodules on the Minera1-Resources Maps. Areas known to be covered with cobalt-rich crust have not been shown because specific data were not available. Nevertheless, a statement prepared for the accompanying text points out that all seamounts in the west-central Pacific above $2,500 \mathrm{~m}$ are potential areas for the development of cobalt-rich crusts. Allen Clark of the East-West Resource Systems Institute in Honolulu announced that his group was compiling a Pacific-wide inventory of cobalt- and manganeserich crusts. He said that work had progressed to the point that it might be possible to map the distribution in certain areas, citing maps of the Hawailan 
Islands that denote seamount accumulations of economic interest. Information to be mapped would include thickness and composition, according to Clark. Mckelvey recommended that an effort be made to designate areas of these crusts on the maps that follow the Northeast Quadrant.

\section{GEODYNAMIC MAP SERIES}

The first map in the Geodynamic Series, the Northeast Quadrant sheet, was printed in July 1984 (Drummond, 1984c). It was followed by the Southeast Quadrant (Corvalán, 1984) and the Southwest Quadrant (Doutch, 1985). Proofs of the two remaining 1:10,000,000-scale sheets were completed in late 1984 and were scheduled to be printed during the first half of 1985 .

By January 1985 cartographic work on the 1:17,000,000-scale Pacific Basin sheet was well advanced and publication was expected during the first half of 1985. A draft of the explanatory text for the Series was completed during January 1985 by George W. Moore, editor of the Geodynamic Maps.

At the June 1984 Panel Chairmen's meeting, Moore called attention to the color proofs of the Northeast, Southwest, and Northwest Quadrant Maps on which free-air gravity is depicted in color as the principal element. Gravity contouring over ocean areas is from SEASAT radar-altimeter data (Rapp, 1981), and mean free-air anomalies on land are generalized from traditional fieldgravity measurements.

Other principal elements of the Geodynamic Maps include earthquake focal mechanisms compiled by Frederick Mauk and Arthur Tarr and lithospheric stress arrows compiled principally by Mary Lou Zoback. Holocene volcanic centers, active plate boundaries, and plate-motion vectors are reprinted on the maps from the Plate-Tectonic Series. A 13-percent gray tint has been added to land areas to differentiate them from oceanic areas.

Moore stressed the usefulness of well-ellipticity data determined from four-arm dipmeter surveys of boreholes in lithospheric-stress measurements. An excellent data set for the eastern part of the Canadian Rocky Mountains is included on the Northeast Quadrant Map. Well-ellipticity data are available for China, and Doutch agreed to investigate the availability of dipmeter data for the Southwest Quadrant Map.

The Holocene volcano data set (Simkin and others, 1981) that is being reprinted on the Geodynamic Map Series has been updated through April 1984. A new supplement containing these revisions was made avallable to the Map Project by Simkin. 


\section{Overview}

Important developments in the preparation of the Tectonic Map of the Circum-Pacific Region during 1984 were the completion of a draft map of the Southwest quadrant, the pilot map in this series, and the adoption of a printing schedule for the five 1:10,000,000-scale map sheets. Initial maps in the series-the Southwest and Northwest quadrants--are scheduled for publication during 1986. The final map--the Antarctica Sheet--is scheduled for printing in 1989 (table 8). Compilation guidelines for the Tectonic Map Series are included in table 18 .

\section{Southwest Quadrant}

The Southwest Tectonic Map compilation was completed by Erwin Scheibner during October 1984 and transmitted to Menlo Park for cartography. Yet to be completed at year-end 1984 were structural elements and sediment isopachs for the southeastern part of the Indian Ocean. A conference between the project cartographic staff and a color contractor was held during December to develop plans for computerized scanning and plotting of the color separations for the map. Cartography was scheduled to begin during 1985 upon completion of cartographic corrections and printing of the Geologic Maps of the southwest and Northwest quadrants.

Chief compiler scheibner noted that the basic philosophy of this map series advanced by Terman (1976) was that the Tectonic Maps should have the same unit boundaries as on the Geologic Maps and that the basic tectonic units should be as objective as possible. Plate-Tectonic concepts and other interpretations of the basic basement and cover units are shown by letter symbols on the map. They are keyed to explanatory material in the accompanying text for each map. At this level, multiple tectonic interpretations can be made, but the fundamental units are determined objectively and procedures for their selection will not differ from quadrant to quadrant, according to Scheibner.

Selection of oceanic crustal units for the Southwest Quadrant is based upon major tectonic events such as the breakup of Gondwanaland. Boundaries selected by scheibner fall at or near anomalies $6,18,24,27,34$, and M0 (Pitman and others, 1981). This scheme appears to be applicable to oceanic plates in other parts of the Pacific, according to scheibner. It was recommended that a boundary between the Late Jurassic-Early Cretaceous sequence and the Cretaceous magnetic quiet zone be determined, based on data from the pacific plate. Moore agreed to work with scheibner in making this selection and suggested that additional units in the Jurassic and Lower Cretaceous might be determined through further study. 
Reference to the time-space plots developed for the Southwest Quadrant Map by Scheibner (figure 9) will enable the map user to read out the tectonic position of any rock complex or unit shown on the map. Each tectonostratigraphic terrane (Howell and others, 1985a) should have a separate column on the timespace diagrams. A proposal to include twin columns with volcanic events on one side and plutonic events on the other was rejected by Scheibner because of limited space in the map margins. A sample of the description of units for the Southwest Quadrant Map is included in table 18; this information will be included in the explanatory notes that accompany each map sheet.

\section{Northeast Quadrant}

At the June 1984 meeting Panel Chairman Kenneth J. Drummond indicated that compilation of the Northeast Quadrant Map was still in a preliminary stage and that finalization would await completion of the Energy-Resources Map. George W. Moore presented a preliminary compilation of the Alaskan part of the Tectonic Map. The compilation guidelines adopted at the 1982 Interim Project Meeting (Circum-Pacific Map Project, 1983; table 9) were found to be applicable to Alaska by Moore. Boundaries selected by Moore for tectonic coloring of the oceanic crust in the North Paciflc were somewhat different that those used by Erwin Scheibner on the Southwest Quadrant map. They were chosen, according to Moore, in order to highlight the change in motion of the Pacific Plate coresponding to the Emporer bend and the time of disappearance of the Kula plate. Moore recommended that present-day spreading axes be depicted by a 1,000,000-year wide band, as on the Plate-Tectonic Maps, to provide direct information on rates of spreading.

Drummond advised the Map Committee that significant progress on the Tectonic Map compilation would be registered by the end of 1984 with a target of completing a first draft of the map for the next Panel Chairmen's meeting in mid-1985.

\section{Southeast Quadrant}

A preliminary draft of the Tectonic Map of the Southeast Quadrant by Panel Chairman José Corvalán was displayed at the June 1984 meeting. The map was sufficiently advanced, according to Corvalán, to be copied and distributed to panel members for review.

Corvalan advised the Map Committee that the Commission for the Geologic Map of the World's Tectonic Map of South America (Martín, 1983) could not be used as the source for this map because it was based on material compiled up to 1970 and as such has been eclipsed by later maps. He reported problems in synthesizing the differing criteria utilized in the individual country maps of South America. A particular problem has been generalizing the tectonic map of Argentina, for example, which is divided into regions in which separate subdivisions have been described and mapped. 
In the northern and southern parts of the Andean chain, an alpine-type geosynclinal model can be followed and the general divisions of basement and cover are utilized. The central part of the Andes, however, is a pericratonic basin that is locally called a geoliminar basin or trough (Auboin and others, 1973). Because of these differences, a scheme somewhat different from the guidelines adopted by the Map Committee in 1982 had to be devised.

\section{Antarctica Region}

Initial compilation efforts on the Antarctica Map during 1984 were directed to the wilkes Land Coast opposite the Australian continent. A tectonic map of the region bounded by long $90^{\circ} \mathrm{E}$. and $160^{\circ} \mathrm{E}$. was completed by Campbell Craddock in mid-1984 and furnished to the Southwest quadrant to fill out the commonly-shared overlap area on the Southwest quadrant Map. Compilation of other parts of the map will require accommodation to the Tectonic Maps of the Southwest and Southeast Quadrant. Craddock observed that the Antarctic continent is divisible into two major provinces that align themselves with South America on the one hand and Australia on the other.

\section{Northwest Quadrant}

A target of publishing the Tectonic Map of the Northwest quadrant by July 1986 was declared by Panel Chairman Chikao Nishiwaki at the November 1983 meeting of the Northwest Quadrant Panel in Kuala Lumpur, Malaysia. Important draft compilations of parts of mainland Asia were received from the Soviet Union and China during the first half of 1984 through the cooperation of Circum-Pacific Council Director Nikita Bogdanov and Li Yin-huai, Northwest Quadrant Panel Member, respectively. A second draft was provided by $\mathrm{Li}$ following the 1984 panel Chairmen's meeting. Problems in merging the separate compilations of the Soviet Union and Chinese parts of the map were resolved by Deputy Panel Chairman Tamotsu Nozawa during meetings with Soviet colleagues in Moscow during the XXVII International Geological Congress in August 1984.

As of late 1984, then, all materials for the Northwest Tectonic Map were in the hands of the compilers in Japan. Completion of the first draft of the map was scheduled for the first half of 1985 at a November 22, 1984, meeting in Tsukuba, Japan, between map compilers, Northwest Quadrant Panel officials, and the General Chairman.

Recent 1:10,000,000-scale tectonic and geologic maps of northern Sumatra completed by the British are excellent efforts, according to Erwin Scheibner who recommended that the information be utilized in preparation of the Northwest and Southwest Tectonic Maps and, if possible, the Geologic Maps of these quadrants. It was also recommended that unpublished tectonic-elements and sediment-thickness maps compiled by Frank F. H. Wang of the U.S. Geological Survey be utilized in finalizing offshore parts of Southeast Asia. 


\section{Basin-Wide Data Sets}

Tom Simkin of the Smithsonian Institute advised the Map Project that progress on developing a post-Miocene volcano data base for the Southwest Pacific region was being made. As Simkin had reported to the 1983 Panel Chairmen's meeting, the world-wide post-Miocene volcano data set compiled by the International Association of Volcanology and Chemistry of the Earth's Interior (1973) does not include any data for this region. There is an unpublished compilation for this region that is now more than 15 years old, but its publication is considered doubtful now. Simkin advised that a new start on compiling data from this area needs to be made. Through an exchange of letters with Wallace Johnson, Australian Bureau of Mineral Resources, a form for entering data about post-Miocene volcanic centers prepared by Simkin has been completed, and was ready for distribution to specialists in the Southwest Pacific region. It was clear, however, that the data set will not take shape in time for inclusion on the Tectonic Map of the Southwest Quadrant as once was planned (Addicott, 1983, p. 50).

Xenia Golovchenko described a worldwide compilation of bedrock ages of both the oceans and continents prepared by a team from Lamont-Doherty Geological Observatory and Rhode Island University for publication at 1:23,000,000 scale. The map (Larsen and others, 1985) is based on data included in the Circumpacific magnetic anomaly compilation (Golovchenko and others, 1982), but magnetic lineations are not shown on $i t$.

A letter from John G. Dennis, editor of the International Tectonic Lexicon Group of the Sub-Commission for the Tectonic Map of the World, commenting on terminology in the compilation guidelines adopted by the Panel Chairmen at the 1982 Interim Meeting (Circum-Pacific Map Project, 1983; table 9) was noted and discussed.

\section{ENERGY-RESOURCES MAP SERIES}

\section{Northeast Quadrant}

The Energy-Resources Map of the Northeast Quadrant is serving as the pilot sheet in this series. Preparation of this map began during the early 1970s and culminated with a preliminary color proof in 1978. Work was recessed for several years while the Geologic Map and Tectonic Map were compiled because these maps provide essential background information for the Energy-Resources Map Series. Revision of this map and the addition of new map elements resumed during 1983 as a consequence of modifications to the compilation guidelines adopted at the 1983 Panel Chairmen's meeting (table 19).

$0 i 1$ and gas fields for Canada have been recompiled and new fields off California and Mexico have been added to the 1978 compilation by Kenneth $\mathrm{J}$. Drummond. Panel members Peter Vail and Guillermo P. Salas will review and 
update the fields shown for the United States and Mexico, respectively. This map element is considered to be in final shape by Drummond.

Generalized stratigraphic sections for the Pacific rim were recently added to the map by Drummond; additional sections for basins of the continental interior are not being considered for inclusion on the map. A detailed map of petroleum-producing basins of Southern California is being prepared for inclusion in the explanatory notes, although it might be possible to include as an inset on the map, according to Drummond.

A major revision of coal fields and occurrences of coal in North America was completed by Gordon $\mathrm{H}$. Wood in June 1983. Wood added 348 new occurrences to the existing compilation, noting that many additional fields and occurrences could not be shown because of limitations imposed by the map scale. Review of this compilation by Central American panel members will be arranged during the February 1985 meeting of the Northeast Quadrant Panel.

A preliminary compilation of geothermal data completed prior to the meeting by Theresa Swint was distributed to the panel chairmen. Addicott cautioned that the compilation was incomplete and that assistance from pane1 members from Mexico and Central America will be required. He noted that the guidelines for compilation of this map element were revised in 1984 (table 19). Plans have been made for computer-assisted plotting of an extensive data set of thermal springs for the United States (Berry and others, 1980), according to these guidelines.

Heatflow data which were moved from the Geodynamic Map Series to the Energy-Resources Maps during the 1983 Panel Chairmen's Meeting were furnished to the Map Project by David S. Chapman and Uk Han of the University of Utah during 1983. Spot data in seven classes will be shown by colored symbols on the map sheets (table 19).

\section{Southeast Quadrant}

A preliminary compilation for South America was completed by Glenn F. Brown during 1980, based in part upon work initiated by John C. Maher during the late 1970s. Color proofs were made and reviewed at the 1980 and 1981 Panel Chairmen's meetings. Evaluation of these proofs during the January 1984 meeting of the Southeast Quadrant Panel in Santiago, Chile, resulted in an agreement to recompile parts of the map under the direction of panel member Marcelo Yrigoyen of Argentina.

Panel Chairman José Corvalán informed the Map Project meeting in Honolulu in June 1984 ( $f$ igure 12) that all of the basic map information--geology, isopachs, structure contours, oil and gas fields, coal, and heatflow data-were in hand. The principal panel efforts were now to revise and update the oil and gas field data. New panel members were appointed during 1983 to carry out this work. Stratigraphic sections were still under preparation in late 1984 . 


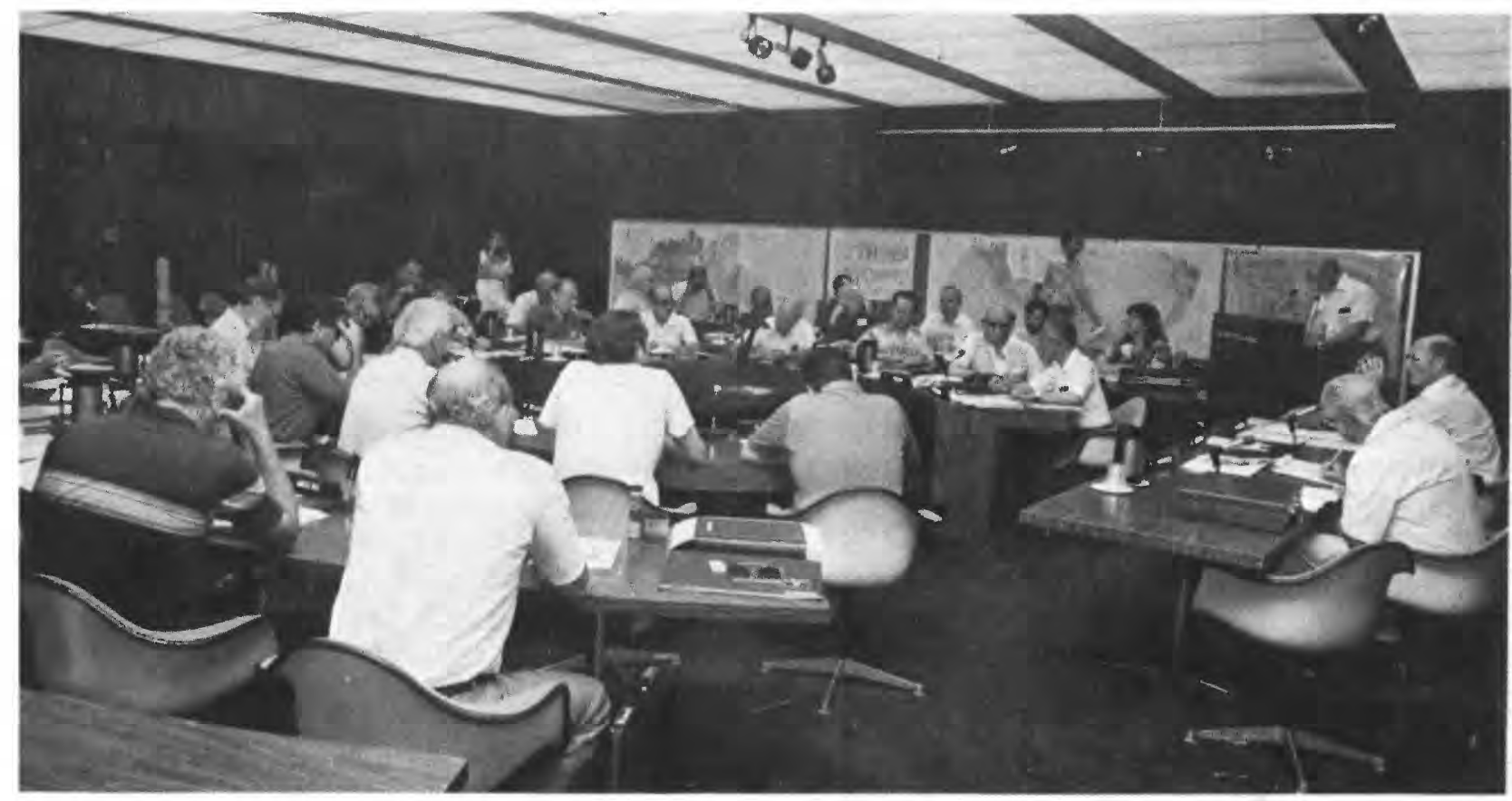

Figure 12. Circum-Pacific Map Project Panel Chairmen's meeting, East-West Center, Honolulu, Hawaii, June 1983.

At the January 1984 Panel Meeting in Santiago the panel members had been requested to complete and correct a preliminary compilation of geothermal convection systems including hot springs with surface temperatures above $50^{\circ}$ C. for inclusion on the southeast Quadrant Map.

\section{Northwest Quadrant}

Deputy Chairman Tamotsu Nozawa informed the June 1984 Map Project meeting that the compilation of geothermal data by Seiya Uyeda was well advanced but not yet complete for the entire map area. A schedule calling for a final compilation of this map to be ready for the June 1985 Panel Chairmen's Meeting was announced, and later confirmed at the subsequent Northwest Quadrant Panel meeting in December.

At the December 1984 meeting of the Northwest Quadrant Panel in Bandung, Indonesia, Eiji Inoue reported that compilation of the oil and gas fields for the Energy-Resources Map had been completed earlier in the year. The coal fields were compiled still earlier. Photocopies of existing compilations of each country were distributed to panel members at the December meeting with the request that corrections and additions to coal and petroleum deposit outlines be made and returned to Inoue by the end of January 1985. 
Inoue said that compilation of this map was well advanced. The geologic background has been divided into four categories: (1) surficial deposits of Quaternary age, (2) Neogene and Quaternary volcanic rocks, (3) strongly deformed Paleozoic and Mesozoic strata, and (4) basement, including Precambrian rocks, metamorphic and intrusive-igneous rocks of various geologic ages on land, and acoustic basement in ocean areas.

\section{Antarctica Region}

Energy-Resources data for the continent of Antarctica are so limited that it was decided during the early stages of map compilation to include them with the Mineral-Resources Map (Richards, 1979). Moore observed that inclusion of hydrocarbon occurrences on this map sheet might cause considerable crowding of data on those parts of the Australian and South American continents that are included on the new Antarctica base. In the case of the Southwest Quadrant, Panel Chairman Doutch said that this probably would not present a serious problem.

Craddock informed the Panel Chairmen that compilation of data had as yet not progressed very far.

\section{Southwest Quadrant}

Compilation of the Energy-Resources Map of the Southwest Quadrant progressed substantially during the first half of 1984 according to Panel Chairman H. Frederick Doutch. The only problems foreseen at that time were in the depiction of coal deposits on the Australian continent. In this respect, Doutch asked for guidance from the Northeast Quadrant in order to develop comparable depiction for the rich Australian deposits. The principal problem that has to be overcome is in the overlapping coal occurrences and the use of brown for outlining these coal-bearing areas.

0il-shale deposits have been compiled and can be included on the map without seriously obscuring other information according to Doutch. The heatflow compilation received from project headquarters in 1983 had been reviewed by panel experts, and certain additional data were planned to be added to it.

Compilation of geothermal resources had not yet been initiated as of mid-1984. Doutch requested information on geothermal features in the western part of the Southeast Asia-Indonesia overlap area from the Northeast Quadrant Panel.

A target for the completion of a first draft of the map was set for the early part of 1985 by Doutch. Addicott requested that the Northwest Quadrant focus their compilation ef forts on the overlap area with the Southwest Quadrant so that a manuscript map of the Southwest Quadrant could be completed prior to the mid-1985 Map Project meeting. 


\section{Explanatory Notes}

Copies of a preliminary manuscript of the explanatory notes for the Energy-Resources Map of the Northeast Quadrant were distributed to participants at the June 1984 Panel Chairmen's meeting. Author Kenneth J. Drummond, observing that the manuscript was intended to be descriptive and documentary, cautioned that it was still in the formative stages. Index maps showing the major sedimentary basins, their names, and classification are included in the manuscript. Patterning is utilized to indicate those that contain giant oil and gas fields. Also included are reserves by country and production for the most recent year. Oil fields with ultimate producible reserves greater than $100,000,000$ barrels and gas fields with greater than 600,000,000,000 cubic feet of gas are also tabulated. United States Panel Member Peter Vail is working with Drummond on developing these data. Sections on coal production and reserves and geothermal fields are planned. A glossary of terms is under preparation. Drummond's manuscript was commended by the other Panel Chairman who declared that the format will be followed by their panels' manuscripts, although preparation is not as advanced as the Northeast Quadrant manuscript.

\section{PACIFIC BASIN MAPS}

During 1983 it was discovered that the scale of the Pacific Basin base map was very close to $1: 17,000,000$ rather than a scale of $1: 20,000,000$ which had been printed on the three total-area maps issued up to that time. On maps printed prior to 1984, the bar scale and numerical scale, therefore, are incorrect. A proposal presented at the June 1984 Panel Chairmen's meeting to issue new maps at 1:20,000,000 scale was not adopted, owing to the fact that a map at that scale would not adequately fill the standard 101.6 by $137.2 \mathrm{~cm}$ paper size. Future Pacific Basin maps will carry a revised bar scale reflecting the $1: 17,000,000$ scale.

\section{Plate-Tectonic Map}

A second reprinting of the Plate-Tectonic Map of the Pacific Basin was completed during 1984. Included were minor revisions based on new seafloor data off Antarctica and in the Scotia Sea. This has been the most successful Circum-Pacific map sheet published with 3,600 copies printed so far.

Manganese Nodule, Seafloor Sediment, and Sedimentation Rate Map

A color proof of the Pacific Basin Manganese Nodule Map was completed during May 1984 and was presented to the 1984 Panel Chairmen's meeting by David Z. Piper for evaluation and discussion. The map was approved for publication by the Panel Chairmen at their June meeting, and significant additions to the map were completed by Piper and Theresa Swint in October. 
At year-end 1984 cartographic corrections had progressed to the point that publication was scheduled during the first half of 1985.

This map includes bottom photographic stations and nodule abundance contouring generalized from proofs and compilation copy for the seafloor minerals element of the Mineral-Resources Maps. Chemical analyses of nodules and core data are not shown on the 1:17,000,000-scale map. Seafloor-sediment distribution derived from the basin-wide compilation by Floyd $w$. McCoy for the Geologic Map series has been generalized from 13 to 7 units which are shown in color. The smear-slide and secondary data points are not included on this map. Sediment-accumulation rates are noted by red-colored symbols and are depicted by linear map patterns in four categories: less than 1 $\mathrm{mm} / 1000$ years, $1-5 \mathrm{~mm} / 1000$ years, $5-15 \mathrm{~mm} / 1000$ years, and greater than 15 $\mathrm{mm} / 1000$ years.

At the 1984 Panel Chairmen's meeting, Piper noted that the nodules occur in areas of slow sediment accumulation and are of most common occurrence in the eastern and southern parts of the Pacific Ocean. McKelvey pointed out that the nodules are also largely confined to areas of red clay and siliceous ooze. He recommended that further discussion of what this map shows be included in the explanation so as to complement the description of compilation procedures and data sources. He also recommended that this, and other Circumpacific Maps, be accompanied by texts that present the data and findings to a much broader spectrum of map users than the specialist. After extensive discussion, it was agreed that the Manganese Nodule Map description should be expanded to include the recommended commentary on the distribution of nodules in the context of bottom sediment, bathymetry, and sediment accumulation rate. Piper agreed to prepare the additional text to be included on the second color proof scheduled for completion during the first quarter of 1985.

Cobalt and manganese crusts have not been included on the Pacific Basin map because the data are as yet too sparse for inclusion, according to McKelvey. It may be possible, however, to delineate cobalt-rich crusts on some of the 1:10,000,000-scale Mineral-Resources Maps which are not scheduled for immediate publication. It was agreed by the Panel Chairmen that publication of the Mineral-Resources Map of the Northeast Quadrant, then scheduled for late 1984, should not be delayed while an effort was made to assemble available data on cobalt-rich crusts.

\section{Seafloor Sediment Map}

In actions taken at the 1983 Panel Chairmen's meeting, a 1:17,000,000scale map of seafloor sediments, to be compiled from the $1: 10,000,000$-scale Geologic Map Series, had been approved for inclusion in the Circum-Pacific series. But at the recommendation of the principal compiler, Floyd w. McCoy, it was decided in June 1984 not to issue this map. The generalized sediment distribution depicted on the Manganese Nodule Map of the Pacific Basin was considered to adequately depict this parameter. 


\section{Tectonostratigraphic Terrane Map}

A Preliminary Tectonostratigraphic Terrane Map of the Circum-Pacific Region (Howell and others, 1985a) was approved for inclusion in the CircumPacific Series during the June 1984 Panel Chairmen's meeting. The map was prepared in cooperation with the Map Committee but largely outside of its regional map compilation program. It is a direct outgrowth of the CircumPacific Terrane Conference held at Stanford University in August and September 1983 (Howell et al, 1984). Folded copies of the map are to be included in the conference proceedings volume (Howell and others, 1985b); the anticipated press run is 4,000 copies with 1,500 additional maps to be printed for distribution as individual sheets. A chapter from the volume describing the individual terranes will be reprinted and distributed with the individual map sheets. The map was published in January 1985, and the conference proceedings was scheduled for printing in April 1985.

The Tectonostratigraphic Terrane Map shows accreted terranes divided into two age categories and further subdivided into oceanic rocks, mixed continentally-derived sediments and oceanic rocks, oceanic volcanic island arcs, volcanic arcs on continentalized basement, and continental fragments. Also shown are oceanic plateaus in four classes, composite terranes, overlap sequences, zones of pluton stitching, regional belts of Archaean and Proterozoic rocks, and rifted continental crust. Active plate boundaries and relative plate motions from the Plate-Tectonic Series (Drummond and others, 1982) are included, as is an inset map showing ages of accretion (Archaean, Proterozoic, Paleozoic, and Mesozoic, and Cenozoic). Individual terranes are designated by letter symbols that correspond to names and detailed information contained in the accompanying text (Howell and others, 1985b).

The Tectonostratigraphic Terrane Map was not intended to complement the 1:10,000,000-scale Tectonic Map Series, as noted by H. Frederick Doutch at the June 1984 Panel Chairmen's meeting. He pointed out that the map originated outside of the Map Project's normal program, although some participants in the program have been involved in its compllation and preparation.

\section{Geologic Map}

At the 1983 Panel Chairmen's meeting, Southeast Quadrant Panel Chairman José Corvalán D. agreed to prepare a sample compilation of the Geologic Map of the Southeast Quadrant on the 1:17,000,000-scale base. Corvalán reported to the 1984 meeting that preliminary work on Chile and Argentina at that scale resulted in the loss of a great deal of information. His view was that the map should be generalized from the more detailed quadrant maps and that no new data should be added. Kenneth J. Drummond reported that a similar effort with part of the Geologic Map of the Northeast Quadrant also resulted in the loss of considerable information. He pointed out, however, that generalized geology at 1:17,000,000 scale was going to be necessary to provide a background for other thematic map compilations at that scale. 
Discussion of the oceanic part of the map led to the proposal that oceanic crustal ages be depicted rather than seafloor sediments, in part owing to the inclusion of sediments on the Manganese Nodule Map. In this case, the map would be substantially different from the 1:10,000,000-scale Geologic Map Series. Doutch reminded the chairmen that much of this information was soon to be published on a bedrock geology map of the world (Larsen and others, 1985).

A plan for developing at least partial compilations of land geology on the $1: 17,000,000$-scale base by the five regional panels and utilizing oceanic crustal ages compiled for the Map Project by Xenia Golovchenko was adopted at the 1984 meeting. It was proposed that the continental shelves be printed in a neutral tone on this map. It is expected that the Panel chairmen will report on their compilations at the 1985 meeting, at which time a formal schedule for producing this map will be considered.

\section{Geodynamic Map}

Map Editor George W. Moore advised the 1984 Panel Chairmen's meeting that all of the elements for this map excepting topography for the land areas were at hand. Drummond's suggestion that the map be issued without topography if compilation of that element would unduly delay publication was accepted. Moore advised that most of the map elements were in digital format. Focal mechanisms and state of lithospheric stress arrows probably will have to be thinned somewhat from the 1:10,000,000-scale maps to be included on the Pacific Basin map.

At year-end 1984, work was well advanced on the Geodynamic Map of the Pacific Basin. Cartographer Frank Sidlauskas scheduled completion of a color proof during the early part of 1985 and printing of the map during the first half of 1985 .

\section{Hazards Map}

At the 1984 Panel Chairmen's meeting it was proposed that a Hazards Map, including data on earthquake and volcanic hazards, information from the NOAA tsunami map (Lockridge and Smith, 1984), landslides, and flood hazards be prepared by the Map Project. A preliminary landslide map presented to the 1980 Panel Chairmen's meeting (Brabb, in Addicott, 1980, p. 29) was referred to as a guide to depicting data on the Pacific Basin Sheet. The idea was generally accepted by the Panel Chairmen and it was suggested that a small group of experts with active experience in mapping geologic hazards be empaneled to experiment with depicting information on the 1:17,000,000-scale base map. Herbert Meyers advised the group that examples of hazards maps covering the entire globe, some at smaller scales than the Circum-Pacific base, have been prepared to depict recurrence rates of certain threshold events. A further suggestion was to use the ocean areas to show limits of polar ice packs, common areas of waterspouts, or common paths of hurricanes. 
Headquarters was asked to look into the possibility of compiling a map of geologic hazards and that experts be queried about the feasibility of this kind of map. Once a prospectus can be developed, it should be sent to the Panel Chairmen for evaluation and further ideas with discussion to follow as an agenda item at the 1985 Panel Chairmen's meeting.

Later in the year Peter B. Humphrey of the East-West Center drafted a list of proposed elements for a hazard map (table 20) which was circulated to the Panel Chairmen for study and comment. Humphrey called attention to a natural hazards map of the Southeast Asian region (Moyan and Valuria, 1983) in which earthquake hazards, volcanoes, tsunamis, and typhoon tracks are depicted (figure 13).

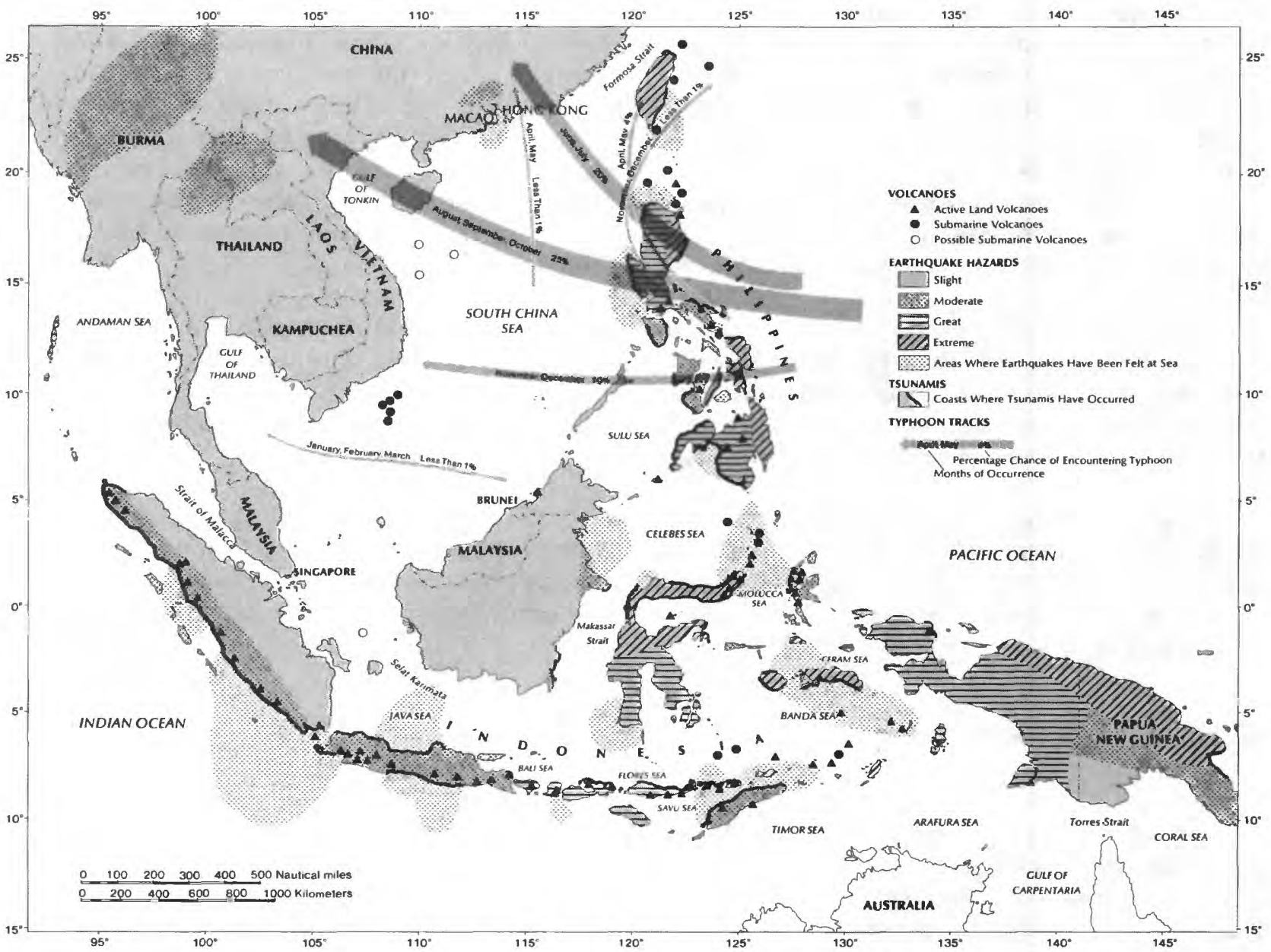

Figure 13. Natural hazards map of the Southeast Asian region (from Morgan and Valencia, 1983). 


\section{Energy Resources Map}

Proposed guidelines for a 1:17,000,000-scale Energy-Resources Map of the Circum-Pacific Region prepared by former Map Project Deputy Chairman Paul W. Richards in cooperation with Kenneth J. Drummond were presented at the 1983 Panel Chairmen's meeting (table 21). Although there were no objections to the proposed guidelines, no formal action was taken at that time.

\section{Tsunami Map}

At the June 1984 Panel Chairmen's meeting, Herbert w. Meyers of the World Data Center A, Boulder, Colorado, displayed a color proof of a new map showing 20th-Century tsunamis on the 1:17,000,000-scale Circum-Pacific base. The map depicts events that produced 1900-1983 tsunamis by symbols indicating earthquake or volcanic eruption or landslide. The map was printed later in the year (Lockridge and Smith, 1984). Color is used to indicate earthquake magnitude and. symbol size to denote runup height of individual tsunamis. Included on the map are tabular data keyed to map locations listing dates of the tsunamis, related earthquakes, results of the tsunamis, and sources of data. The map was prepared by the National Geophysical Data Center and world Data Center $A$ in cooperation with the U.S. Office of Foreign Disaster Assistance of the Agency for International Development.

It was agreed that the tsunami map should be published with a circumPacific Council and Map Project identification and it was further recommended that the Map Committee be included in the distribution of the map. Addicott and Reinemund were authorized to review the color proof with Meyers for adequacy of identification with the Circum-Pacific effort.

Meyer noted, in his report to the Map Committee, that the global bathymetric data base available through world Data Center A was planned to be updated by October 1984. At that time an improved northern hemisphere data base was scheduled for completion and would furnish good global coverage on a five-minute grid.

\section{EXPERIMENTAL MAPS}

A color proof of an experimental metallogenic map of the Northeast Quadrant by John P. Albers was completed during the first half of 1983 and was presented to the Panel Chairmen at the June 1983 meeting in Honolulu. The object of the map, according to Albers, is to depict the relationship of various types of mineral deposits to specific terranes. He indicated that trends of mineral belts correlate rather closely with accreted terranes throughout the western Cordillera. Scarn-type iron deposits, serpentinites, alpine peridotites, and massive sulfide deposits tend to occur in accreted arc terranes, according to Albers. Other examples include lode-type gold 
deposits that occur principally in accreted oceanic terrane, and mercury, which occurs in oceanic crustal terrane in California and in accreted arc terrane in Nevada and in Mexico. Albers emphasized that his map was a departure from the established 1:10,000,000-scale Circum-Pacific series in that it was experimental in nature whereas the established map series emphasize basic data.

The concept of this map excited the interest of the Panel Chairmen and was endorsed by a majority of them. It was decided that color copies of the proof be made and circulated to the Panel Chairmen following the meeting for further study and comment.

Following the 1983 meeting, Albers concluded that the number of mineral deposit types--about 20--was too large to include successfully on an individual map sheet. He then decided to display the information on several smaller map sheets at a scale of 1:20,000,000 to be issued as a folio. The first three of these sheets were presented at the 1984 Panel Chairmen's meeting. One map depicted the major terrane types to be used as a tectonic background for the other maps: oceanic crust, accreted terrane, continental crust, together with subdivisions of them. A second map showed mineral belts or provinces for mercury, uranium, lead, and zinc. A third map included iron skarn deposits, fluorospar, and three kinds of manganese deposits.

Michel $T$. Halbouty encouraged Albers to find a way in which the information could be shown on a ful1-size 1:10,000,000-scale map in addition to the possibility of using a series of smaller maps. Later, it was suggested that, rather than a series of maps in a folio, the mineral provinces be combined onto four maps at an approximate scale of $1: 20,000,00$ and included as panels on a map sheet of the same dimensions as the 1:10,000,000-scale maps. The question of depicting information in seafloor areas of the maps was also raised. One possibility that will be explored by Albers would be to use the seafloor area for the placement of descriptive text for each of the maps.

McKelvey encouraged a wide review of the map compilation and further study of the possibility of depicting information in the oceanic areas. He also expressed an interest in extending the map to the other quadrants of the Pacific and then utilizing the Pacific Basin Sheet as a base map.

A four-map depiction of 24 mineral deposit types at 1:20,000,000-scale was completed by Albers in late 1984. These four maps on the above-indicated terrane background were to be combined onto one standard-sized map sheet--102 by $137 \mathrm{~cm}-$-and then distributed to the Panel Chairmen and technical reviewers during the first quarter of 1985. 


\section{Background}

At the August 1982 Interim Meeting of the Map Project in Honolulu, Circum-Pacific Council Director Michel $T$. Halbouty suggested that the Map Committee compile detailed geologic and resource maps of developing countries as a second phase of project work. The Southeast Asia region was cited as a likely starting point. Ernest $P$. DuBois, then senior petroleum geologist on the staff of the Coordinating Committee for offshore Exploration for Mineral Resources in Southeast Asia (CCOP), voiced support of this proposal, noting that a hydrocarbon assessment program that was being initiated by CCOP in this region in cooperation with other regional organizations was compatible with the Halbouty proposal for second phase CPMP work. Plans for a coordinated effort by the Map Project with its mechanism for compiling, preparing, and publishing maps and by CCOP with its hydrocarbon assessment program emerged in the months following the 1982 meeting.

During a January 1983 seminar on the development of regional geological programs in developing countries held in Bangkok it was recommended that a basin-analysis program be initiated in Southeast Asia. The program would be carried out through the operational framework of the Northwest Quadrant Panel of the Circum-Pacific Map Project in cooperation with CCOP and under the overall direction of the IUGS Research Development Program. In addition to a mapping effort to compile geological, geophysical, and resources data, the program would include as a principal objective the assessment of hydrocarbon resources in the region (Reinemund, 1984b). The Bangkok seminar was jointly sponsored by IUGS, ESCAP, AGID, and UNESCO. It was later recognized that IUGS had already laid some of the ground work for this program through the Commitee on Storage, Automated Processing, and Retrieval of Geologic Data's (COGEODATA) regional program of petroleum data compilation and systematization in Southeast Asia a few years earlier. The COGEODATA program was carried out in cooperation with CCOP and, in part, led to the subsequent plans for CCOP's hydrocarbon assessment project.

At the 1983 Panel Chairmen's meeting in Honolulu, a proposal to initiate a regional mapping program in Southeast Asia was approved in principle with the proviso that pilot projects were to be carried out to ascertain the feasibility of this work. Results of these were to be reported to the 1984 meeting at which time formal action would be taken. The work, to be carried out in cooperation with IUGS and CCOP, would involve compilation and publication of a series of maps at a scale of $1: 2,000,000$ and related cross sections. Management of the Circum-Pacific Map Project participation would be through the Northwest Quadrant Panel. The Southeast Asia program would be an initial activity under the IUGS world-wide program of evaluating sedimentary basins for resources potential. Under the direction of CPMP Scientific Advisor Maurice J. Terman, a layout of seven map sheets at a scale of 1:2,000,000 on the Lambert azimuthal equal-area projection with a center point of $120^{\circ} \mathrm{E}$ and 


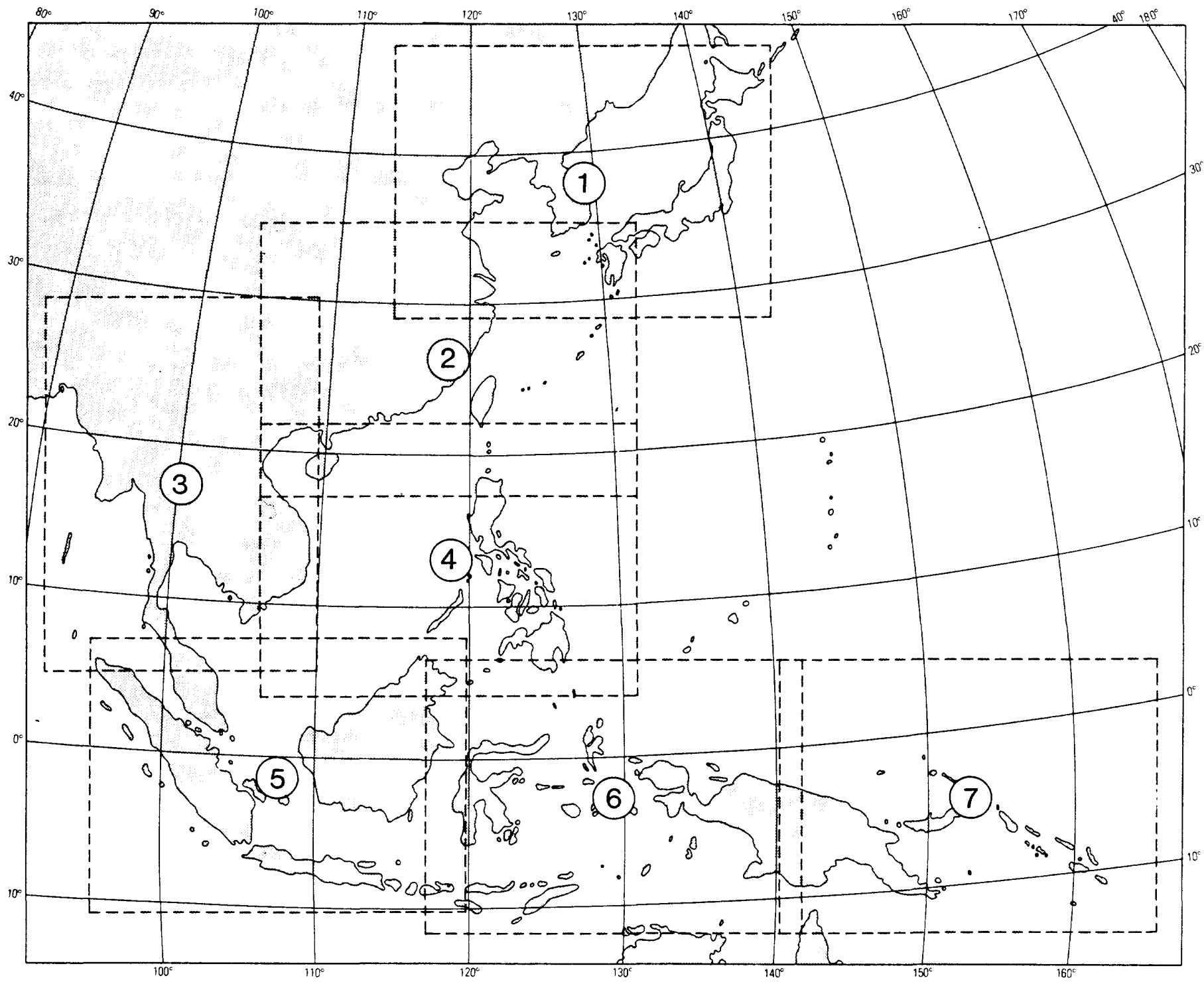

Figure 14. Index to map sheets for the Southeast Asia Basin Evaluation Program. The seven 1:2,000,000-scale maps are on a Lambert equal-area projection with a center point of $15^{\circ} \mathrm{N}$. and $120^{\circ} \mathrm{E}$. 
$15^{\circ} \mathrm{N}$. was completed during 1983. Slight modifications of map-sheet boundaries called for by members of the Northwest Quadrant Panel at the November 1983 Panel Meeting in Kuala Lumpur resulted in redrawing certain map boundaries (figure 14 ).

At the 1983 CCOP meeting in Kuala Lumpur the program was approved, under the title IUGS/CCOP/CPMP evaluation of sedimentary basins for resource potential, by CCOP member countries.

During the last quarter of 1983 a six-month pilot project in the circum-Borneo region was initiated by KeIth Robinson of the U.S. Geological Survey in cooperation with CCOP staff members.

At a planning meeting convened by IUGS in Madrid in April 1984 (table 22 ), representatives from participating organizations, including John $A$. Reinemund from the Map Project, specified that the planned maps, cross sections, and reports need to be complemented by resource assessments based in part on these products. In particular, formulation of guidelines on how to use these data for resource assessments was requested.

\section{Consideration of Program at 1984 Panel Chairmen's Meeting}

Reinemund summarized the status and intended scope of the Southeast Asia Basin Evaluation Program at the 1984 Panel Chairmen's meeting in Honolulu, forecasting that the Map Project would play an instrumental role in this work. Regional agencies would be expected to carry the early stages of basicdata gathering and map compilation because they have direct access to requisite data bases and can operate most efficiently at this stage. His view was that the late stages would see the Map Project taking a major role in review, formatting, cartography, and publication of the maps. It was stressed that all sedimentary resources were to be included in the evaluation program, not just petroleum.

Reinemund pointed out that a COGEODATA workshop on resource assessment methodology held in Buenos Aires in 1983 led to plans for a similar basin-analysis project in the Chaco-Paraña basin in South America. This hydrocarbonoriented project would involve five South American countries. It was noted that the organizers of this IUGS-sponsored activity are looking to the Southeast Asia Program for guidelines. As the Chaco-Paraña project area lies on the east side of the Andean chain, it was considered unlikely that the Map Project would be actively involved in this effort.

The results of the six-month pilot study of the circum-Borneo region was presented to the 1984 Panel Chairmen's meeting by Keith Robinson. Much of the effort had been expended in collecting data from various agencies and companies operating in the area. Preliminary products exhibited at the meeting included a map showing sedimentary basins compiled by Ernest $P$. DuBois, a map showing depth to "economic" basement with a 1,000-meter contour 
interval, detailed sediment-thickness maps of the Paleogene and the Neogene, and paleoenvironmental/paleogeographic maps of the Paleogene and the Neogene. Also presented were diagrammatic cross sections showing types of oil and gas plays in relationship to paleogeographic and structural settings in the circum-Borneo region.

Arthur Saldivar-Sali, a Director of the Circum-Pacific Council, discussed the desirability of the ASEAN Council on Petroleum (ASCOPE) joining in the IUGS/CCOP/CPMP Basin Evaluation Program. Enlisting their participation in this effort could be difficult, he said, because both the Circum-Pacific Council and the Map Project and their scientific outreach were not particularly well-known in Southeast Asia. He recommended that the Council or the Map Project be represented at the next ASCOPE meeting in order to explain the Southeast Asia program and its potential benefits. The probability of significant technology transfer would be especially valued as would the end result of enabling individual countries to assess their own resource potentials. Nevertheless, the countries involved in this work would need to be shown the specific products that would come out of this work and the advantages that would accrue from them. Although broad-gauge studies of all sedimentary resources are planned, it was Saldivar-Sali's view that hydrocarbons be emphasized. A specific proposal for ASCOPE participation should include the overall concept, the organizational framework, personnel requirements and prospective funding, and a firm schedule of work units. Saldivar-Sali offered to communicate a proposal from the Map Project and Circum-Pacific Council to ASCOPE at the time of their November 1984 meeting and specifically asked that a letter be generated from this meeting.

In discussion of the Southeast Asia Basin Evaluation Program, Doutch raised the question of whether this type of regional activity would create an Imbalance within the Map Project framework, pointing out that similar projects would need to be started up in other quadrants and in Antarctica to maintain the Circum-Pacific focus.

Nishiwaki indicated that the Northwest Panel would cooperate fully in preparation of a series of maps similar to those that Robinson had prepared for the circum-Borneo area. Some modification of the Northwest Quadrant Panel structure will be necessary, however, to carry out this new phase of map compilation, according to Nishiwaki, and funding problems will have to be addressed and solved to permit the work to move forward. He cautioned that the project would probably move slowly and that ample time should be built into the schedule of work units.

Reinemund summarized the proposed division of work, stressing that the individual countries would compile the maps and that the Map Project, in his view, would produce the final maps in addition to the base maps already under preparation. The IUGS role, he said, would be the provision of consultants, as needed, and the sponsorship of workshops and training seminars. The CircumPacific Map Project would, in his view, provide management and cartographic support, although neither would necessarily conflict with the completion of Phase I map production. 
Finally, the Panel Chairmen voted unanimously to support the Southeast Asia Basin Evaluation Program and, at the same time, asked that detailed definition of the program and map-compilation guidelines be developed. It was specified that Phase I activities were to be concluded before any significant cartographic effort is allocated to the new program.

\section{Review of the Program at the XXI Meeting of CCOP}

Preliminary base maps of map sheets 1 (Japan/Korea), 3 (Thailand), and 5 (Malaysia and western Indonesia) were presented at the XXI CCOP meeting in Bandung, Indonesia, in November and December 1984 (figure 14). A schedule for cartographic preparation of the base maps, calling for completion of shoreline and bathymetry in July 1985 and of topography in July 1986, was presented (table 22).

It was agreed that the first phase of mapping would be carried out in Indonesia and in Thailand, based in part on the availability of base maps and already-compiled information. More definitive plans were to be developed at a late January 1985 meeting in Virginia, at which time planning for the 3rd CCOP hydrocarbon resources assessment workshop, to be held in Kuala Lumpur during July and August 1985, by representatives from CCOP, IUGS, CPMP, USGS, and GSC, was to be completed. A two-day session on developing data and compilation guidelines for the mapping in western Indonesia and in Thailand and other areas was to be included in the meeting agenda. A steering committee to oversee the basin evaluation project was scheduled to be named during the Kuala Lumpur meeting.

\section{CIRCUM-PACIFIC CONFERENCE}

Preliminary plans for Map Project participation in the IV Circum-Pacific Conference on Energy and Mineral Resources to be held in Singapore August 17-22, 1986, called for a symposium of papers, entitled The Tectonic Development of the Circum-Pacific Region and Mineral Resources. A plan for the proposed session was prepared by Erwin Scheibner, who reasoned that by the time of the Singapore Conference the Map Project will have published most of the planned maps and that a symposium on the relationship of mineral resources to tectonic development would be a natural culmination of the current phase of project work. The proposal was forwarded to the Conference Chairman, Allen G. Hatley. Late in 1984 Hatley responded with a counter proposal under which the Map Project would have a half-day session of papers of their choosing, a late-afternoon or early-evening session of informal poster-session papers, and discussion on current map compilations, and a prominent display of published map sheets.

It was specifically requested that a paper on map cartography including the use of computers in scanning and digitizing map compilations and in 
plotting the printing plates be presented. It was further recommended that the poster-session presentation of map compilations should focus on the Minera1-Resources and Energy-Resources Maps. Further consideration of the Map Project contributions was to be discussed at the regional panel meetings in late 1984 and early 1985.

Addicott recommended that the 1986 Panel Chairmen's meeting be held in Singapore immediately preceding the Circum-Pacific Conference. His suggestion was recommended to the Circum-Pacific Council for consideration and approval. 
References Cited

Addicott, w. O., 1980, Status of the Circum-Pacific Map Project: U.s. Geological Survey Open-File Report 80-1059, 77 p.

Auboin, J., A. V. Borrello, and G. Cecioni, 1973, Esquisse paléogeographique et éstructurale des Andes Meridionales: Revue de Geographie Physique et de Geologie Dynamique, ser. 2, v. 15, fasc. 1-2, p. 11-72.

Berry, G. W., P. J. Grim, and J. A. Ikelman, 1980, Thermal springs list for the United States: U.S. National Oceanic and Atmospheric Administration Key to Geophysical Records Documentation 12, 59 p.

Corvalán D., J., 1985, Geodynamic Map of the Circum-Pacific Region, Southeast Quadrant: Tulsa, Oklahoma, American Association of Petroleum Geologists, scale $1: 10,000,000$.

Coury, A. B., and Hendricks, T. A., 1978, Map of prospective hydrocarbon provinces of the world: U.S. Geological Survey Miscellaneous Field Studies Maps $M F-1044 A$ and $M F-1044 C$, scale $1: 20,000,000$.

Doutch, H. F., 1985, Geodynamic Map of the Circum-Pacific Region, Southwest Quadrant: Tulsa, Oklahoma, American Association of Petroleum Geologists, scale $1: 10,000,000$.

Drewry, D. J., ed., 1983, Antarctica: glaciological and geophysical folio: Scott polar Research Institute, Cambridge University, 9 map sheets, various scales.

Drummond, K. J., 1983, Geologic Map of the Circum-Pacific Region, Northeast Quadrant: Tulsa, Oklahoma, American Association of Petroleum Geologists, scale $1: 10,000,000$.

- 1984a, Geodynamic Map of the Circum-Pacific Region, Northeast Quadrant: Tulsa, Oklahoma, American Association of Petroleum Geologists, scale 1:10,000,000.

Quadrant: Tulsa, Oklahoma, American Association of Petroleum Geologists, scale $1: 20,000,000[1: 17,000,000]$.

Drummond, K. J., C. Nishiwaki, J. Corvalán D., H. F. Doutch, and C. Craddock, 1982, Plate-Tectonic Map of the Circum-Pacific region, Pacific Basin sheet: Tulsa, Oklahoma, American Association of Petroleum Geologists, scale $1: 10,000,000$. 
Drummond, K. J., F. W. McCoy, G. W. Moore, T. R. Swint, and w. O. Addicott, 1983, Explanatory notes for the Geologic Map of the Circum-Pacific Region, Northeast Quadrant: Tulsa, Oklahoma, American Association of Petroleum Geologists, 36 p. [1984].

Golovchenko, X., R. L. Larson, W. C. Pitman III, 1982, Magnetic lineations: Plate-Tectonic Map, Circum-Pacific Region, Pacific Basin Sheet: Tulsa, Oklahoma, American Association of Petroleum Geologists, scale $1: 20,000,000[1: 17,000,000]$.

Halbouty, M. T., 1970, World's giant oil and gas field, geologic factors affecting their formation and basin classification, in M. T. Halbouty, ed., Geology of giant petroleum fields: American Association of Petroleum Geologists Memoir 14, p. 502-555.

Halbouty, M. T., J. C. Maher, and H. M. Lian, eds., 1976, Circum-Pacific Energy and Mineral Resources, papers from the Circum-Pacific Energy and Mineral Resources Conference held August 26-30, 1974, in Honolulu, Hawaii: Tulsa, Oklahoma, American Association of Petroleum Geologists, $608 \mathrm{p}$.

Harper, G. D., 1984, Plate-Tectonic Map of the Circum-Pacific Region (review): Journal of Geological Education, v. 32, no. 2, p. 127.

Howell, D. G., D. L. Jones, A. Cox, and A. Nur, 1984, Proceeding of the CircumPacific Terrane Conference: Stanford University Publications in Geological Sciences, v. 28,248 p.

Howe11, D. G., D. L. Jones, and E. R. Schermer, 1985a, Explanatory notes to accompany the map Preliminary Tectonostratigraphic Terranes of the Circum-Pacific Region: Houston, Texas, Circum-Pacific Council for Energy and Mineral Resources, 28 p.

Howell, D. G., E. R. Schermer, D. L. Jones, Z. Ben-Avraham, and E. Scheibner, 1985b, Preliminary Tectonostratigraphic Terrane Map of the Circum-Pacific Region: Houston, Texas, Circum-Pacific Council for Energy and Mineral Resources, scale, 1:17,000,000.

International Association of Volcanology and Chemistry of the Earth's Interior, 1973, Data sheets of the post-Miocene volcanoes of the world with index maps: Rome, d'Antimi, 15 sheets, pagination by sheet.

Larsen, R. L., X. Golovchenko, and W. C. Pitman III, 1981, Geomagnetic polarity time scale, in K. J. Drummond, chairman, Geologic Map of the Circum-Pacific Region, Northeast Quadrant: Tulsa, Oklahoma, American Association of Petroleum Geologists, scale 1:10,000,000.

Larsen, R. L., W. C. Pitman III, X. Golovchenko, S. C. Cande, J. F. Dewey, W. F. Haxby, and J. L. Labrecque, 1985, The bedrock geology of the world: New York, W. H. Freeman and Company, scale 1:23,230,300. 
Lockridge, P. A., and R. H. Smith, 1984, Tsunamis in the Pacific basin 1900-1983: Boulder, Colorado, National Geophysical Data Center and World Data Center A for Solid Earth Geophysics, scale 1:17,000,000.

Martín, C. F., 1983, Metallogenic map of South America: Ministry of Energy and Mines, Venezuela, 2 sheets, scale 1:5,000,000.

Morgan, J. R., and M. J. Valencia, eds., 1983, Atlas for marine policy in southeast Asian seas: Berkeley, University of California Press, $145 \mathrm{p}$.

Piper, D. Z., T. R. Swint, F. W. McCoy, and L. G. Sullivan, 1985, Manganese Nodule, Seafloor Sediment and Sedimentation Rates of the Circum-Pacific Region: Tulsa, Oklahoma, American Association of Petroleum Geologists, scale $1: 17,000,000$.

Radkevich, E. A., E. G. Bel'tenev, B. C. Egiazarov, and L. I. Krasny, eds., 1979, Metallogenic map of the Pacific ore belt vladivostok, USSR Academy of Sciences, Far-East Geological Institute, 10 sheets, scale $1: 10,000,000$.

Rapp, R. H., 1981, The earth's gravity field to degree and order 180 using SEASAT altimeter data, terrestrial gravity data, and other data: Ohio State University Department of Geodetic Science and Surveying Report No. $322,53 \mathrm{p}$.

Reinemund, J. A., 1984a, Significance of the Circum-Pacific Map Project as a mechanism of geoscience cooperation and research: Geologisches Jahrbuch A76, p. 11-26.

- - 1984b, Development and coordination of regional geological programs in southeast Asia, in J. A. Katili and J. A. Reinemund, Southeast Asia: tectonic framework, earth resources, and regional geological programs: International Union of Geological Sciences pub. 13, p. 1-15.

Richards, P. W., 1979, Status of the Circum-Pacific Map Project: U.S. Geological Survey Open-File Report 79-1561, 38 p.

Simkin, T., L. Siebert, L. McClelland, D. Dubridge, C. Newhall, and J. H. Latter, 1981, Volcanoes of the world, a regional directory, gazetteer, and chronology of volcanism during the last 10,000 years: stroudsburg, Pennsylvania, Hutchison and Ross, 236 p.

St. John, B. E., 1980, Sedimentary basins of the world and giant hydrocarbon accumulations: Tulsa, Oklahoma, American Association of Petroleum Geologists, 23 p., map scale 1:40,000,000.

Terman, M. J., 1978, Tectonic maps for the Circum-Pacific Map Project: U.S. Geological Survey Open-File Report 78-118, 10 p. 
U.S. Geological Survey, 1983, Circum-Pacific Map Project: 1982 status report: U.S. Geological Survey Open-File Report 83-64, 117 p. 
Table 1. Acronyms used in this report.

\begin{tabular}{|c|c|}
\hline AAPG & American Association of Petroleum Geologists \\
\hline AGID & Association of Geoscientists for International Development \\
\hline APEA & Australian Petroleum Exploration Association \\
\hline ARCO & Atlantic Richfield oil Company \\
\hline ASCOPE & ASEAN Council on Petroleum \\
\hline ASEAN & Association of Southeast Asian Nations \\
\hline BGR & Federal Republic of Germany Bundestalt fur Geowissenschaften \\
\hline BMR & $\begin{array}{l}\text { Australia Bureau of Mineral Resources } \\
\text { und Rohstoffe }\end{array}$ \\
\hline CCOP & $\begin{array}{l}\text { ESCAP Committee for Coordination of Joint Prospecting for } \\
\text { Mineral Resources in East Asian of fshore Areas }\end{array}$ \\
\hline CCOP/SOPAC & $\begin{array}{l}\text { ESCAP Committee for Coordination of Joint Prospecting for } \\
\text { Mineral Resources in South Pacific Offshore Areas }\end{array}$ \\
\hline CERESIS & $\begin{array}{l}\text { Centro Regional de Seismologia para America del Sur/ } \\
\text { Regional Center for Seismology of South America }\end{array}$ \\
\hline CGMW & IUGS Commission for the Geological Map of the World \\
\hline COGEODATA & $\begin{array}{l}\text { IUGS Committee on Storage, Automatic Processing, and } \\
\text { Retrieval of Geological Data }\end{array}$ \\
\hline COP/CNEXO & $\begin{array}{l}\text { Centre Oceanologique du Pacifique/Centex National pour } \\
\text { l'Exploration des Oceans }\end{array}$ \\
\hline CPCEMR & Circum-Pacific Council for Energy and Mineral Resources \\
\hline CPMP & Circum-Pacific Map Project \\
\hline DSDP & Deep Sea Drilling Project \\
\hline ESCAP & $\begin{array}{l}\text { United Nations Economic and Social Commission for Asia and } \\
\text { the Pacific }\end{array}$ \\
\hline GAPA & $\begin{array}{l}\text { Geological and Geophysical Atlas of the Pacific and Atlantic } \\
\text { Oceans }\end{array}$ \\
\hline GEBCO & General Bathymetric Chart of the Oceans \\
\hline
\end{tabular}


GSA

GSC

IDOE

IHO

INETER

IOC

IPA

IPOD

IUGS

JAPEX

NASA

NOAA

ORSTOM

PAIGH

PSA

SCAR

SCOR

SEAPEX

SEATAR

SUNY

UNESCO

UNEP

USGS

VSEGEI
Geological Society of America

Geological Survey of Canada

International Decade of Ocean Exploration

International Hydrographic Or.ganization

Instituto Nicaraguense de Estudios Territoriales

Intergovernmental Oceanographic Commission

Indonesian Petroleum Association

International Program for Ocean Drilling

International Union of Geological Sciences

Japan Petroleum Exploration Company

U.S. National Aeronautic and Space Administration

National Oceanic and Atmospheric Administration

Office de la Recherche Scientifique et Technique d'Outre Mer

Pan American Institute for Geography and History

Pacific Science Association

Scientific Committee for Antarctic Research

Scientific Committee on Ocean Research

Southeast Asia Petroleum Exploration Society

Studies of East Asia Tectonics and Resources (CCOP/IOC)

State University of New York

United Nations Educational, Scientific, and Cultural Organization

United Nations Environmental Programme

United States Geological Survey

U.S.S.R. All-Union Geological Institute 
Table 2. Status of incomplete Circum-Pacific 1:10,000,000-scale Map Series as of January 1985.

Map Series

GEOLOGIC

TECTONIC
Element

Map Sheet

NW SW AN SE NE

Panels

Hdqs .

Hdqs.

Hdqs .

H/P

Geology of ocean areas

Faults

Panels

Explanatory text

H/P

Panels

Panels

Faults, incl. historic \& postMiocene

Active plate boundaries

Isopachs, seafloor sediment

Isopachs, land areas

Salt domes, areas of

Diatremes, crypto-explosion structures

Age of oceanic crust

Geochronologic data (rock ages)

Paleomagnetic data

Explanatory texts

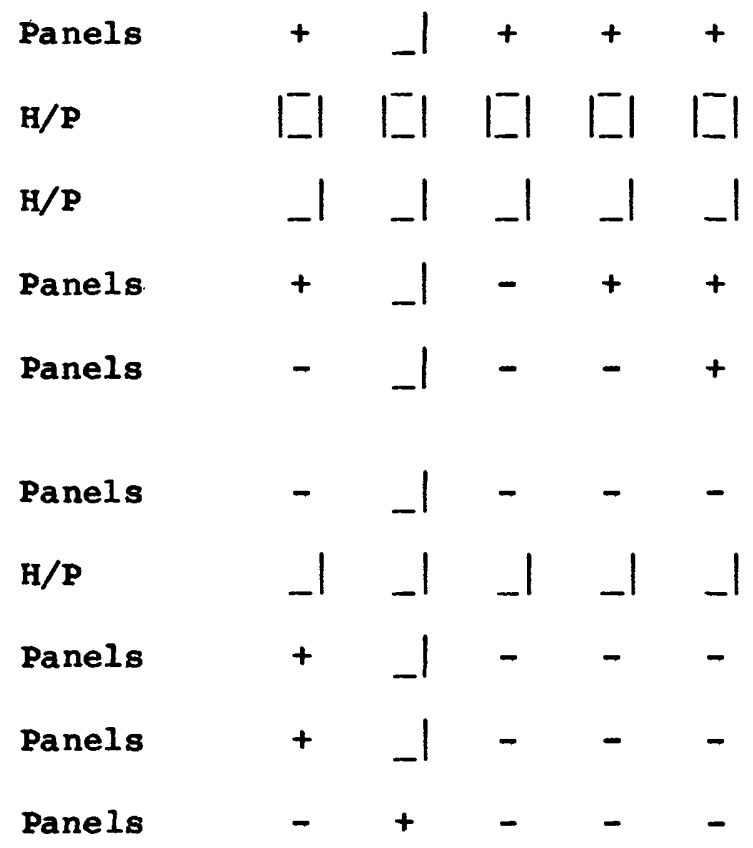


Table 2, pg. 2

Open-File Report 85-267

Map

GEODYNAMIC

Volcanoes, Holocene

Focal mechanisms

Gravity

Lithospheric stress

Seismic epicenters

Active plate boundaries

Crustal thickness

Explanatory text for series

Mineral deposits on land

Seafloor mineral data

Geologic/tectonic background

Seafloor sediment

Explanatory texts

Oil and gas fields

Oil shale, tar sands

Coal-bearing areas

Isopachs, land areas,

Isopachs, seafloor sediment

Selected stratigraphic columns

Heatflow, spot data

Geothermal sites

Explanatory text
Quadrant/Status

NW SW AN1/ SE NE

Hdqs .

II I I I I

Hdqs.

$\left[\begin{array}{lllll}\mid & | \pm| & \mid \Xi & | \pm| & | \pm|\end{array}\right.$

Hdqs.

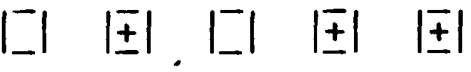

Panels

$\mid \begin{array}{lllll}\mid & | \pm| & \mid \Xi & | \pm| & | \pm|\end{array}$

Hdqs .

$\mid \begin{array}{lllll}\mid & | \pm| & \mid \Xi & | \pm| & | \pm|\end{array}$

Hdqs. $\quad I_{-} \mid \begin{array}{lllll} \pm & I_{-} & \Xi & \Xi & \Xi\end{array}$

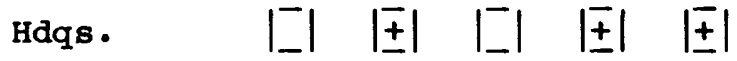

Hdqs. II I I I I I I

Panels $++\ldots||| \pm|$

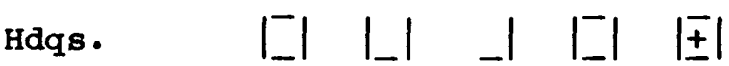

Panels $+++| \pm|$

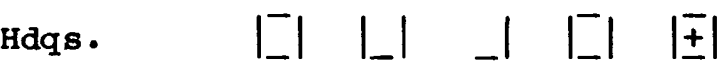

$\mathrm{H} / \mathrm{P}$

Panels

Panels

Panels

Panels

Hdqs.

Panels

Hdqs.

Panels

Panels

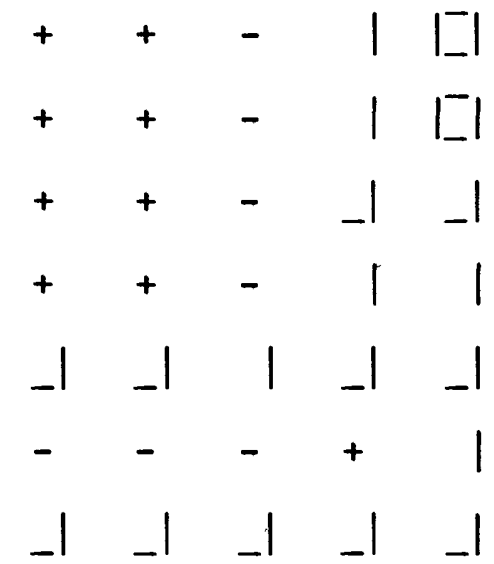

$+\quad-\quad+$

\begin{tabular}{|c|c|c|c|c|c|c|}
\hline MINERAL RESOURCES & Mineral deposits on land & Panels & + & + & & \\
\hline & Seafloor mineral data & Hdqs. & $I_{-1}$ & & & \\
\hline & Geologic/tectonic background & Panels & + & + & + & \\
\hline & Seafloor sediment & Hdqs. & $I_{-}^{-}$ & & & \\
\hline & Explanatory texts & $\mathrm{H} / \mathrm{P}$ & - & - & - & \\
\hline ENERGY RESOURCES & Oil and gas fields & Panels & + & + & - & \\
\hline & Oil shale, tar sands & Panels & + & + & - & \\
\hline & Coal-bearing areas & Panels & + & + & - & \\
\hline & Isopachs, land areas, & Panels & + & + & - & \\
\hline & Isopachs, seafloor sediment & Hdqs. & -1 & - & 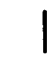 & \\
\hline & Selected stratigraphic columns & Panels & - & - & - & + \\
\hline & Heatflow, spot data & Haqs. & -1 & 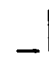 & 1 & \\
\hline & Geothermal sites & Panels & + & - & - & + \\
\hline & Explanatory text & Panels & - & - & 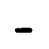 & \\
\hline
\end{tabular}


Table 2, pg. 3

Open-File Report 85-267

- not compiled

$+\quad$ partially compiled

I some material submitted to project hdqs.

- I completed and submitted to project hdqs.

I_l cartography completed

I. proof completed

\pm pubiished

1/ Energy deposits to be combined with mineral data on Mineral-Resources Map of Antarctica 
Table 3

Open-File Report 85-267

Table 3. Officers and Directors of the Circum-Pacific Council for Energy and Mineral Resources

DIRECTOR

Michel T. Halbouty

COUNCIL OFFICERS

President - Michel T. Halbouty

First Vice-President - J. Erick Mack, Jr.

Second Vice-President - Allen G. Hatley

Secretary - Mary Stewart

Treasurer - H. Gary Greene

Chaiman, Public Affairs - Anthony P. Hatch

EXECUTIVE DIRECTOR

John A. Reinemund, U.S.A.

COUNCII DIRECTORS

Warren 0. Addicott, U.S.A.

Ismet Akil, Indonesia

Nikita A. Bogdanov, U.S.S.R.

Robert J. Foster, Australia

William w. Hutchison, Canada

David Rear, New Zealand

Harold M. Lian, U.S.A.

Allen Mabra, U.S.A.

Tamotsu Nozawa, Japan

Maria T. Calas Pinochet, Chile

John A. Reinemund, U.S.A.

Roye W. R. Rutland, Australia

Guillermo P. Salas, Mexico

A. Saldivar-Sali, Philippines

Carlos del solar, peru

Zhai Guangming, China 
Table 4

Open-File Report 85-267

Table 4. Members of the Circum-Pacific regional panels and map consultants.

NORTHWEST QUADRANT PANEL

CHAIRMAN : Chikao Nishiwaki

Japan

Members

Li Yin-huai

China

Ismet Akil

Indonesia

H. M. S. Hartono

Indonesia

Fred Hehuwat

Noriyuki Fujii

Yutaka Ikebe

Eiji Inoue

Yasufumi Ishiwada

Indonesia

Japan

Japan

Japan

Masaharu Kamitani

Japan

Hisao Kuwagata

Tomoyuki Moritani

Japan

Japan

Japan

Tamotsu Nozawa

Japan

Tadashi Sato

Japan

Y. Shimazaki

Japan

Yoji Teraoka

Japan

Seiya Uyeda

Japan

Takashi Yoshida

Japan

S. K. Chung

Dominador $\mathrm{H}$. Almogela

Malaysia

Guillermo R. Balce

Juanito C. Fernandez

Philippines

Philippines

Philippines

Froilan Gervasio

Chong Su Kim

No Young Park

Sangad Bunopas

Phisit Dheeradilok

Kaset Pitakpaivan

Michael Churkin

Maurice J. Terman

Philippines

Rep. of Korea

Rep. of Korea

Thailand

Thailand

Thailand

USA

USA

Frank F. H. Wang

USA

L. I. Krasny

USSR

V. B. Kurnosov

USSR

V. G. Moiseenko

USSR

N. A. Shilo

USSR

Formex Members

Zhang Wen-you

China

Ismet Akil

Indonesia

Djumhani

Indonesia

Raden Hardjono

Indonesia 
Osamu Hirokawa Shun-ichi Sano Masatochi Sogabe Masashi Yasui Sang Ho Um Oscar Crispin Allen G. Hatley Richard W. Murphy S. Kaewbaidhoon M. G. Ravich
Japan

Japan

Japan

Japan

Korea

Philippines

SEAPEX

SEAPEX

Thailand

USSR

SOUTHWEST QUADRANT PANEL

CHAIRMAN : H. F. Doutch

Australia

Members

R. N. Richmond

APEA

J. N. Casey

D. Denham

N. Exon

D. Falvey

W. Johnson

D. Palfxeyman

E. Scheibner

P. Wellman

L. Machesky

P. Rodda

J. Recy

H. R. Katz

D. Kear

K. Doble

S. Danitofea

Former Members

Graham Maxwe 11 David Forman G. H. Packham Gladys Warren James V. Eade

A. J. Halunan

H. Rotschi

Alexander Macfarlane

D. I. J. Mallick

J. W. Brodie

R. W. Willett

H. L. Davies

R. B. Thompson

Y. Morel

APEA

Australia

Australia

Australia

Fiji

Fiji

New Caledonia

New Hebrides

New Hebrides

New Zealand

New Zealand

Papua New Guinea

Solomon Islands

Tahiti 
ANTARCTICA REGION PANEL

CHAIRMAN : Campbe11 Craddock

USA

Members

R. L. Oliver

Oscar González-Ferran

Raymond J. Adie

G. W. Grindley

Charles R. Bentley

David H. Elliot

Arthur B. Ford

Dennis E. Hayes

G. E. Grikurov

Former Members

William R. MacDonald

James M. Schopf

F. Alton Wade

M. G. Ravich
Australia

Chile

Great Britain

New Zealand

USA

USA

USA

USA

USSR

USA

USA

USA

USSR

SOUTHEAST QUADRANT PANEL

CHAIRMAN: José Corvalán

Chile

Members

Marcelo R. Yrigoyen

Raúl Rolíz

Eduardo Gonzáles P.

Alfredo Lahsen A.

Carlos Mordojovich

Constantino Mporozis

Hermann Duque-Caro

Fernando Etayo S.

Michel Hermelin

Giovani Rosania

Horacio Rueda

H. G. Barsczus

Umberto Dueñas

Argentina

Bolivia

Chile

Chile

Chile

Chile

Colombia

Colombia

Colombia

Ecuador

Ecuador

France

Perú

Victor R. Eyzaguirre P.

Perú

Gregorio Pardo

Nestor Teves

Perú

Pe rú

George E. Ericksen

USA

J. Erick Mack, Jr.

Emilio Herrero

USA

Nelly Pimentel B.

Venezuela

Venezuela 
Table 4 pg. 4

Open-File Report 85-267

Former Members

Vincent H. Padula

Argentina

Juan Carlos Turner

Argentina

Carlos Salinas E.

Bolivia

Jaime Cruz

Colombia

Hernan Garces G.

Colombia

Michel Hermelin

Colombia

Rodrigo Alvarado

Ecuador

Edmundo Lanas C.

Ecuador

Gaston Ruales

Eleodoro Bellido B.

Ecuador

Alberto Giesecke

Jose Lizárraga R.

Fernando Zuñiga

Alirio Bellizzia

Jose Antonio Galavis

Perú

Perú

Perú

Perú

Venezuela

Henrique $J$. Lavie

Venezuela

Cecilia Martín B.

Venezuela

Venezuela

\section{NORTHEAST QUADRANT PANEL}

CHAIRMAN : Kenneth J. Drummond

Canada

Members

R. L. Chase

Canada

Kenneth M. Dawson

Canada

Hubert Gabrielse

Canada

Geoffrey B. Leech

Canada

Rolando Castillo

Costa Rica

Fernando Rudín

Ricardo Burgos Oviedo

Costa Rica

Gabriel Dengo

Oscar Salazar C.

Estuarto Velasquez V.

Marco Zuniga

G. P. Salas

Glen Hodgson Valrey

Julio Merida

E1 Salvador

Guatemala

Guatemala

Guatemala

Honduras

Mexico

Nicaragua

Panama

James E. Case

USA

Philip W. Guild USA

Allen Lowrie USA

Ray G. Martin USA

George W. Moore USA

R. H. Stewart USA

J. L. Stewart USA

Peter R. Vail USA 
Table 4, pg. 5

Open-File Report 85-267

Former Members

Richard L. Chase

Canada

Geoffrey B. Leech

Canada

Julio Bran Valencia

El Salvador

Samuel Bonis

Guat ema la

Creighton Burk

USA

George Gryc

USA

Anton Klaver

USA

Ralph Mober1y

USA

David Scholl

USA

MAP COORDINATION CONSULTANTS

$\begin{array}{ll}\text { Xenia Golovchenko } & \text { Marine Magnetics } \\ \text { Philip W. Guild } & \text { Minerals } \\ \text { George W. Moore } & \text { Marine Geology } \\ \text { David Z. Piper } & \text { Marine Minerals } \\ \text { Paul W. Richards } & \text { Energy } \\ \text { Arthur C. Tarr } & \text { Seismology } \\ \text { Tom Simkin } & \text { Volcanology } \\ \text { Richard H. Rapp } & \text { Gravity } \\ \text { Jacqueline Mammerickx Winterer } & \text { Bathymetry }\end{array}$

MAP INFORMATION CONSULTANTS

Allen L. Clark

James Marsh

Richard D. Brown

Frederick J. Mauk

Thomas E. Chase

Gordon H. Packham

Robert G. Coleman

Wilbur A. Rinehart

Hugo Cortés G.

Lee Siebert

Pow-Foong Fan

Stuart Smith

Paul J. Grim

David R. Soller

Douglas M. Kinney

Michael Lee

Theresa R. Swint

Frank F. H. Wang

SPECIAL CONSULTANTS

John P. Albers (U.S. Geological Survey)

Mikhail N. Alekseev (Geological Institute, USSR Academy of Sciences)

David S. Chapman (University of Utah)

Thomas A. Davies (International Program for Ocean Drilling)

Edward M. Davin (International Decade of Ocean Exploration)

olivier Dottin (Commission for the Geologic Map of the Wor1d) 
Table 4, pg. 6

Open-File Report 85-267

David Howell (U.S. Geological Survey)

Charles J. Johnson (East-West Center)

L. D. Kulm (Oregon State University)

Roger L. Larson (University of Rhode Island)

C. Y. Li (East-West Center)

Floyd W. McCoy (Lamont-Doherty Geologica1 Observatory)

Vincent E. McKelvey (U.S. Geological Survey)

Herbert W. Meyers (National Geophysical Data Center)

William A. Nierenberg (Scripps Institution of Oceanography)

Dallas L. Peck (U.S. Geological Survey)

Walter C. Pitman III (Lamont-Doherty Geological Observatory)

Tom Simkin (U.S. National Museum)

Lawrence W. Sullivan (Lamont-Doherty Geological Observatory)

Manik Talwani (Gulf Research and Development Company)

Anthony B. Watts (Lamont-Doherty Geological Observatory)

A. I. Zhamoida (All Union Geological Institute, U.S.S.R.)

Mary Lou Zoback (U.S. Geological Survey) 
Table 5

Open-File Report 85-267

Table 5. Organizations cooperating with or providing information for the Circum-Pacific Map Project.

\section{Governmental Agencies}

Argentina Servicio Nacional Minero Geológico

Australia Bureau of Mineral Resources (BMR)

Bangladesh Geological Survey

Bolivia Yacimientos Petrolíferos Fiscales

Centre Océanologique du Pacifique/Centre National pour l'Exploration des Oceans (COP/CNEXO), Tahiti

Chile Empresa Nacional del Petróleo

Chile Servicio Nacional de Geología y Minería

Colombia Instituto Nacional de Investigaciones Geológico Mineras

Cook Islands Department of Survey and Physical Planning

Ecuador Dirección General de Geología y Minería

Ecuador Dirección Nacional de Hidrocarburo

El Salvador Centro de Investigaciones Geotécnicas

Federal Republic of Germany Bundesanstalt fur Geowissenschaften und

Rohstoffe (BGR)

Fiji Mineral Resources Department

Geological Survey of Canada

Geological Survey of Japan

Guatemala Instituto Geográfico Nacional

Guatemala Instituto Nacional de Vulcanología, Sismología, Meterología, e Hidrología

Honduras Dirección General de Minas e Hidrocarburos

Indonesia Geological Survey

Indonesia Ministry of Mines

Kiribati Ministry of Natural Resources Development

Korea Research Institute for Geosciences and Minera1 Resources

Malaysia Federal Geological Survey

Mexico Consejo de Recursos Minerales

New Caledonia Bureau de Recherche Geologique et Minieres

New South Wales Geological Survey, Australia

New Zealand Geological Survey

Nicaragua Instituto de Estudios Territoriales (INETER)

office de la Recherche Scientifique et Technique d'Outre Mer (ORSTOM)

Centre, New Caledonia

office de la Recherche Scientifique et Technique d'Outre Mer (ORSTOM), Tahiti

Panama Dirección General de Recursos Minerales

Papua New Guinea Geological Survey

Perú oficina Nacional de Evaluación de Recursos Naturales

Perú Ministerio de Energía y Minas

Perú Servicio de Geología y Minería

Philippine Bureau of Mines, Department of Agricultural and Natural

Resources 
Servicio Geológico de Bolivia

Smithsonian Institution

Solomon Islands Ministry of Natural Resources

Thailand Department of Mineral Resources

Tonga Lands, Surveys, and Natural Resources Department

Trust Territories of the Pacific, Resources and Development Department

U.S. Board of Geographic Names

U.S. Defense Mapping Agency

U.S. Department of Energy

U.S. Geological Survey (USGS)

U.S. National Aeronautic and Space Administration (NASA)

U.S. National Geophysica1 Data Center

U.S. National Oceanographic and Atmospheric Administration (NOAA)

U.S. Naval Oceanographic of fice

U.S. Naval Ocean Research and Development Activity

U.S.S.R. Academy of Sciences, Far East Center

Vanuatu Geological Survey

Venezuela Ministerio de Energía y Minas

\section{Institutes}

A11-Union Geological Institute (VSEGEI), USSR

Apia Observatory, Cook Islands

Centro de Estudios Geol6gicos de America Centra1

Centro Regiona1 de Sismología para América del Sur

Earthquake Research Institute, University of Tokyo

Far East Geological Institute, Vladivostok, USSR

Geological Institute, Academia Sinica

Geological Institute of Mines and Metallurgy, Peru

Geophysical and Polar Research Center, University of Wisconsin

Hawaii Institute of Oceanography

Institute of Arctic Geology, Ministry of Geology of the USSR

Institute of Geological Sciences, United Kingdom

Institute of International Mineral Resources Development

Institute of the Lithosphere, USSR Academy of Sciences

Institute of Mineralogy and Ore Deposites, Aachen

Institute of Polar Studies, Ohio State University

Instituto de Geográfico Nacional de Guatemala

Instituto de Investigaciones de Chile

Instituto Geográfico de Costa Rica

Instituto Geológico Minero y Metalurgico (INGEMNET)

Instituto Politecnico Nacional (México)

Lamont-Doherty Geological Observatory

National Institute of Geology and Mining, Indonesia

New Zealand Oceanographic Institute

Pan American Institute of History and Geography (PAIGH)

Resources Systems Institute, East-West Center

Far East Center of the USSR Academy of Sciences

Scott Polar Research Institute, Cambridge

Scripps Institution of Oceanography 
Universities

Arizona State University

Australian National University

Colorado School of Mines

Columbia University

Escuela Centroamericana de Geología

Escuela Politecnica Nacional, Ecuador

Florida State University

Johns Hopkins University

Kobe University

Imperial College of Science and Technology, London

Michigan State University

Middlebury College

Ohio State University

Oregon State University, School of Oceanography

Stanford University

State University of New York (SUNY), Albany

Texas $A$ and $M$ University

Texas Technical University

Tsukuba University

Universidad de Argentina

Universidad de Chile

Universidad de Costa Rica

Universidad Nacional Autonoma de México

Universidad Nacional de Honduras

Universidad Nacional F. Villareal (Perú)

Université de Paris Sud

University of Adelaide, Australia

University of California, Santa Cruz

University of Capetown, South Africa

University of Michigan

University of Rhode Island

University of Singapore

University of Southern Mississippi

University of Sydney

University of the South Pacific, Kiribati

University of Texas

University of Tokyo

University of Western Australia

University of Wisconsin

\section{Companies}

Atlantic-Richfield oil Company (ARCO)

Chevron Overseas Petroleum, Inc.

Compania Minería Autlan, S.A.C.V. (México)

Compania Minería Avino (México)

Compania de Minas Buenaventuras, S.A. (Perá) 
Table 5, pg. 4

Open-File Report 85-267

Esso Exploration, Inc.

Esso Exploradora y Productora, Argentina, Inc.

Exxon Production Research Co.

Geociencias Aplicadas, S. A.

Gulf Research and Development Company

Japan Petroleum Exploration Company (JAPEX)

Kennecott Exploration Inc.

Mauricio Hochschild y Cia. (Perú)

Marathon 011 Company

Mobil Oil Company, Canada

Occidental Bolivana, Inc.

Occidental Petroleum, Perú

Pertamina

Petroleos del Perú (PETROPERU)

Petróleos Mexicanos (PEMEX)

Teledyne Geotech

Union oil Company of California

Commissions and Societies

American Association of Petroleum Geologists (AAPG) (publisher)

ASEAN Council on Petroleum (ASCOPE)

Australian Petroleum Exploration Association (APEA)

Centro Regional de Seismología para America del Sur (CERESIS)

Circum-Pacific Council for Energy and Mineral Resources

Commission for the Geologic Map of the World (CGMW)

Deep Sea Drilling project (DSDP)

General Bathymetric Chart of the Oceans (GEBCO), a project of the International Oceanographic Commission (IOC) and the International Hydrographic Organization (IHO)

Geological Society of America

Geological Society of Japan

Intergovernmental Oceanographic Commission (IOC) Central Editorial Board for

Geological/Geophysical Atlases of the Atlantic and Pacific Oceans

International Decade of Ocean Exploration (IDOE)

International Geodynamics Project

International Geological Correlation Programme

International Program for Ocean Drilling (IPOD)

International Union of Geological Sciences

Pacific Science Association

Scientific Committee on Oceanic Research (SCOR), International Council of Scientific Unions

Southeast Asia Petroleum Exploration Society (SEAPEX) (NW Panel Membership)

United Nations Asia and Pacific Branch

United Nations Economic and Social Commission for the Pacific, Natural

Resources Division/(ESCAP)

United Nations Committee for Co-ordination of Joint Prospecting for Mineral

Resources in Asian offshore Areas (CCOP) 
Table 5, pg. 5

Open-File Report 85-267

United Nations Committee for Co-ordination of Joint Prospecting for Mineral

Resources in South Pacific offshore Areas (CCOP/SOPAC)

United Nations Environmental Program (UNEP)

United Nations Mineral Prospecting Branch

United Nations Ocean Economics and Technology Branch

Volcanological Society of Japan

World Data Center A, Boulder, Colorado

Summary:

The 173 organizations in this listing are categorized as follows:

\begin{tabular}{lr} 
Governmental agencies & 55 \\
Institutes & 29 \\
Universities & 39 \\
Companies & 22 \\
Commissions and societies & 28 \\
\multicolumn{1}{c}{ Total } & 173
\end{tabular}

These organizations represent 47 different countries or protectorates. A few additional countries contributed directly to the regional panels, but are not known to headquarters. There are some 20 cooperating international organizations not identifiable with any one country.

The countries, including island nations and protectorates, that have contributed to this work in one way or another include:

Argentina
Australia
Bangladesh
Bolivia
Brazil
Canada
Chile
China
Colombia
Cook Islands
Costa Rica
Cuba
Ecuador
El Salvador
Federal German Republic
Fiji
France

Argentina

Bolivia

Brazil

Chile

China

Colombia

Cook Islands

Costa Rica

Cuba

Ecuador

El Salvador

Fiji

France

\author{
French Polynesia (Tahiti) \\ Guatemala \\ Honduras \\ Indonesia \\ Japan \\ Kiribati \\ Korea \\ United Kingdom \\ Uruguay \\ USA \\ USSR \\ Vanuatu \\ Venezuela \\ Western Samoa \\ Malaysia \\ Mexico \\ New Caledonia
}


Table 6. Participants in the 1983 Panel Chairmen's Meeting, Honolulu, Hawaii.

Addicott, Warren 0. U.S. Geological Survey Office of International Geology 345 Middlefield Road, MS 952 Menlo Park, California 94025

Albers, John P. U.S. Geological Survey 345 Middlefield Road, MS 901 Menlo Park, California 94025

Bardach, John

East-West Center University of Hawaii 1777 East-West Road Honolulu, Hawail 96848

Nikita A. Bogdanov Director, Circum-Pacific Council Institute of the Lithosphere Academy of Sciences of the U.S.S.R. 22 Staromonetny 109180 Moscow, U.S.S.R.

Thomas Chase U.S. Geological Survey 345 Middlefield Road, MS 999

Menlo Park, California 94025

Corvalán D., José

Departamento de Geología

Universidad de Chile

Casilla 13518, Correo 21

Santiago, Chile

Craddock, Campbell

Dept. of Geology and Geophysics University of Wisconsin

Madison, Wisconsin 53706

Delany, Frances 51, Blvd. Montmorency

75016 Paris, France

Olivier Dottin

Commission for the Geologic Map of the World 51, Blvd. Montmorency 75016 Paris, France
Doutch, H. F.

Bureau of Mineral Resources

Box 378

Canberra City, A.C.T. 2601

Australia

Drummond, Kenneth J.

Mobil 011 Co. of Canada

P.0. Box 4055, Station A

Toronto, Ontario

Canada M5W 2Ml

DuBois, Dr. E. P.

c/O ESCAP

UN Building

Bangkok 2, Thailand

Gartner, Anne

U.S. Geological Survey

Office of International Geology

345 Middlefield Road, MS 952

Menlo Park, California 94025

Godley, Valerie

Dept. of Geology and Geophysics

University of Hawail

Honolulu, Hawaii 96848

Golovchenko, Xenia

Marathon 011 Company

P.0. Box 269

Littleton, Colorado 80160

Greene, H. Gary

U.S. Geological Survey

345 Middlefield Road, MS 999

Menlo Park, California 94025

Guild, Philip W.

596 Belvedere Court

Punta Gorda, Florida 33950

Halbouty, Michel $T$.

5100 Westheimer Road

Houston, Texas 77056 
Howell, David

U.S. Geological Survey

345 Middlefield Road, MS 999

Menlo Park, California 94025

Hutchison, W.W.

Earth Sciences Sector

Dept. of Energy, Mines and Resources

580 Booth St., Rm. 2050

Ottawa, Ontario

Canada K1A OE4

Johnson, Charles

East-West Center

University of Hawaii

177 East-West Road

Honolulu, Hawail 96848

Kellogg, James

Dept. of Geology and Geophysics

University of Hawaii

Honolulu, Hawail 96848

Lee, Michael P.

U.S. Geological Survey

12201 Sunrise Valley Dr., MS 952

Reston, Virginia 22092

Meyers, Herb

Solid Earth Data Service Division

Environmental Data Division

National Oceanographic \& Atmospheric Administration

Boulder, Colorado 80302

Mi1ls, Frances

U.S. Geological Survey

345 Middlefield Road, MS 952

Menlo Park, California 94025

Moore, George W.

U.S. Geological Survey

345 Middlefield Road, MS 999

Menlo Park, California 94025

Muehl berger, $W$. R.

Dept. of Geological Sciences

The University of Texas at Austin

Austin, Texas 78712

\author{
Nishiwaki, Chikao \\ 2-8-8 Nishinogawa \\ Komae-shi \\ Tokyo 182, Japan \\ Nozawa, Tamotsu \\ Geology Dept., Faculty of Science \\ University of Shimane \\ 1060 Nishikawatsu \\ Matsue, Japan 690 \\ Pintz, William \\ East-West Center \\ University of Hawaii \\ 1777 East-West Road \\ Honolulu, Hawail 96848 \\ Piper, David Z. \\ U.S. Geological Survey \\ 345 Middlefield Road, MS 902 \\ Menlo Park, California 94025 \\ Reinemund, John A. \\ P.0. Box 890 \\ Leesburg, Virginia 96822 \\ Scheibner, Erwin \\ Geological Survey of New South Wales \\ Dept. of Mines and Energy \\ State office Block \\ Phillip Street \\ Sydney, N.S.W. 2000 \\ Australia \\ Sidlauskas, Frank J. \\ Office of International Geology \\ U.S. Geologica1 Survey \\ 12201 Sunrise Valley Dr., MS 917 \\ Reston, Virginia 22092 \\ Simkin, Tom \\ U.S. National History Museum \\ Smithsonian Institute \\ Washington, D.C. 20560 \\ Simpson, Eric S. W. \\ University of Cape Town \\ Rondebosch 7700, South Africa
}


Table 6, pg. 3

Open-File Report 85-267

Terman, M. J.

Office of International Geology

U.S. Geological Survey

12201 Sunrise Valley Dr., MS 917

Reston, Virginia 22092

Wang, Frank F. H.

U.S. Geologica1 Survey

345 Middlefield Road, MS 999

Menlo Park, California 94025 
Table 7

Open-File Report 85-267

Table 7. Published Circum-Pacific Maps_/.

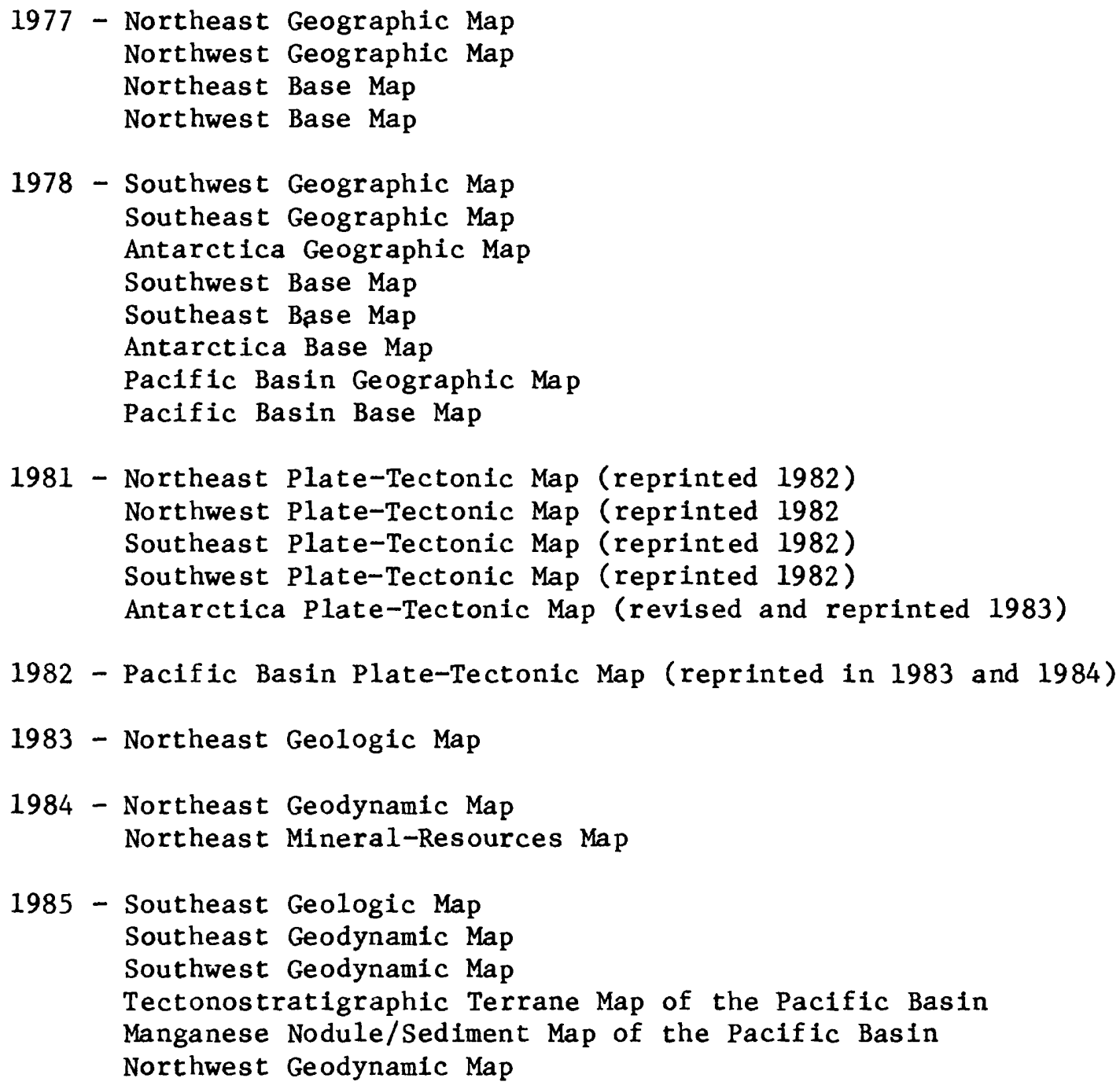

/ Includes map sheets published during the first half of 1985. 
Table 8

Open-File Report 85-267

Table 8. Schedule for publication of the Circum-Pacific thematic maps, 1984-1989.

1984

Northeast

Mineral-Resources

Northeast

Geodynamic
1985

Southeast

Geologic

Southwest

Geologic

Northwest

Geologic

Antarctic

Geologic

Southeast

Geodynamic

Northwest

Geodynamic

Southwest

Geodynamic

Antarctic

Geodynamic

Pacific Basin

Geodynamic

Pacific Basin

Tectonostratigraphic

Terranes
1986

Southwest

Energy-Resources

Southeast

Energy-Resources

Southwest

Tectonic

Northwest

Tectonic

Northeast

Energy-Resources

Southeast

Mineral-Resources

Pacific Basin

Mn/Sediment

Yearly Total:

2 maps

11 maps

6 maps

Cumulative Total:

21 maps

32 maps

38 maps 
Table 8, pg. 2

Open-File Report 85-267

1987

1988

1989

Southeast

Northeast

Pacific Basin

Tectonic

Tectonic

Geologic/Resources

Northwest

Antarctica

Energy-Resources

Tectonic

Southwest

Antarctica

Mineral-Resources

Mineral-Resources

Northwest

Mineral-Resources

Yearly Total:

4 maps

3 maps

1 map

Cumulative Total:

42 maps

45 maps

46 maps 
Table 9. Participants in the 1984 Circum-Pacific Map Project Meeting, Honolulu, Hawail.

Addicott, Warren 0 .

U.S. Geological Survey

Office of International Geology

345 Middlefield Road, MS 952

Menlo Park, California 94025

Albers, John P.

U.S. Geological Survey

345 Middlefield Road, MS 901

Menlo Park, California 94025

Bardach, John

East-West Center

University of Hawaii

1777 East-West Road

Honolulu, Hawaii 96848

Cañas Pinochet, Maria Teresa

Servicio Nacional de Geología y Mineria

Teatinos 120

Santiago, Chile

Clark, Allen

East-West Center

University of Hawaii

1777 East-West Road

Honolulu, Hawail 96848

Cook-Clark, Jennifer

East-West Center

University of Hawaii

1777 East-West Road

Honolulu, Hawaii 96848

Corvalán D., José

Departamento de Geología

Universidad de Chile

Casilla 13518, Correo 21

Santiago, Chile

Craddock, Campbell

Dept. of Geology and Geophysics

University of Wisconsin

Madison, Wisconsin 53706

\author{
Dorian, James \\ East-West Center \\ University of Hawail \\ 1777 East-West Road \\ Honolulu, Hawaii 96848 \\ Doutch, H. F. \\ Bureau of Mineral Resources \\ Box 378 \\ Canberra City, A.C.T. 2601 \\ Australia \\ Drummond, Kenneth J. \\ Mobil 0il Co. of Canada \\ P.0. Box 4055, Station A \\ Toronto, Ontario \\ Canada M5W 2MI \\ Fan, Pow-Foong \\ East-West Center \\ University of Hawaii \\ 1777 East-West Road \\ Honolulu, Hawaii 96848 \\ Gartner, Anne \\ U.S. Geological Survey \\ office of International Geology \\ 345 Middlefield Road, MS 952 \\ Menlo Park, California 94025 \\ Golovchenko, Xenia \\ Marathon Oil Company \\ P.0. Box 269 \\ Littleton, Colorado 80160 \\ Guild, Philip W. \\ 596 Belvedere Court \\ Punta Gorda, Florida 33950 \\ Halbouty, Michel T. \\ 5100 Westheimer Road \\ Houston, Texas 77056
}


Humphrey, Peter

Dept. of Oceanography

University of Hawail

Honolulu, Hawail 96848

Charles J. Johnson

Resource Systems Institute

East-West Center

University of Hawaif

177 East-West Road

Honolulu, Hawail 96848

Kear, David

Department of Scientific and Industrial

Research

Head Office, Private Bag

Wellington, New Zealand

Li, Yin-huai

Institute of Geology

Academia Sinica

P.0. Box 634

Beijing, China

McKelvey, Vincent E.

510 Runnymeade Road

St. Cloud, Florida 32769

Meyer, Herbert

National Oceanographic and Atmospheric Administration

World Data Center A

Boulder, Colorado 80302

Mills, Frances

U.S. Geological Survey

345 Middlefield Road, MS 952

Menlo Park, California 94025

Moore, George W.

U.S. Geological Survey

345 Middlefield Road, MS 999

Menlo Park, California 94025

Nicholson, Pierina (Pat)

Oakland Museum

1000 Oak Street

Oakland, California 94607
Nishiwaki, Chikao

2-8-8 Nishinogawa

Komae-shi

Tokyo 182, Japan

Nozawa, Tamotsu

Geology Dept., Faculty of Science

University of Shimane

1060 Nishikawatsu

Matsue, Japan 690

Piper, David Z.

U.S. Geological Survey

345 Middlefield Road, MS 902

Menlo Park, California 94025

Reinemund, John A.

P.0. Box 890

Leesburg, Virginia 22075

Robinson, Keith

U.S. Geological Survey

P.0. Box 25046

Federal Center, MS 916

Denver, Colorado 80225

Salas, Guillermo P.

Consejo de Recursos Minerales

Av. Niños Heroes, 139

Mexico D. F. 7, Mexico

Saldivar-Sali, A.

Bureau of Energy Development

Ministry of Energy

Merritt Road, Fort Bonifacio

Metro Manila, Philippines

Scheibner, Erwin

Geological Survey of New South Wales

Dept. of Mines and Energy

State office Block

Phillip Street

Sydney, N.S.W. 2000

Australia

Sidlauskas, Frank J.

Office of International Geology

U.S. Geological Survey

12201 Sunrise Valley Dr., MS 917

Reston, Virginia 22092 
Table 9, pg. 3

Open-File Report 85-267

Zhai, Guang-ming

Petroleum Corporation of the PRC

P.0. Box 766

Beijing, China 
Table 10

Open-F1le Report 85-267

Table 10. Report of the 1983 Northwest Quadrant Panel Meeting, Kuala Lumpur, Malaysia.

The ninth session of the Northwest Quadrant Panel of the Circum-Pacific was held on November 14, 1983, in Kuala Lumpur, Malaysia, concurrent1y with the twentieth session of the Committee for Coordination of Joint Prospecting for Mineral Resources in Asian offshore Areas (CCOP). The session was attended by representatives from Quadrant countries including China, Indonesia, Japan, Malaysia, PhIlippines, Republic of Korea, Thalland, and USSR. Observers from Australla, Canada, Federal Republic of Germany, France, Netherlands, Papua New Guinea, and United States were also in attendance. Chikao Nishtwaki, Northwest Quadrant Panel Chatrman, presided.

Warren 0 . Addicott reviewed the status of compilation and the printing schedule for Phase I maps.

Nishiwaki reported that compilation of the Northwest Quadrant Geological Map was completed during May 1983, and is now in cartography at Project Headquarters. Publication of this map was expected by the end of 1984 .

Important contributions to the Tectonfc Map of the Northwest Quarant have been promised by representatives from the Soviet Union by the end of 1983 and from China by the early part of 1984. The Panel Chatrman set the target for publication of this map by mid-1986 so as to be ready for the IV Circum-Pacific Conference, to be held in Singapore. It was noted that a close working relationship with the Southwest Quadrant had alded compllation of most of the island and peninsular area in common to the two maps.

Revised guidelines for the Geodynamic Map were circulated. Panel compilations for this map will consist mainly of the state of lithospheric stress, historically active faults, and earthquake focal mechanisms elements. Other elements are freealr gravity, earthquake first-motion solutions, and Holocene volcanoes. The map compilation is being coordinated by George W. Moore at Project headquarters. Most of the data sets are being supplied by cooperating institutions including the Smithsonian, World Data Center $A$, and Ohio State University.

Panel members in Tokyo will try to compile most of the Energy-Resources Map later this year from avallable data. Th1s will be circulated to panel members for comment and approval.

J. A. Relnemund congratulated the Northwest Panel for its high standards of cooperation and representation from countries within the Quadrant region, noting that the Panel serves as an example for the two eastern Pacific Quadrants that are holding their initial panel meetings late this year and early next year.

Discussion for a cooperative basin evaluation and resources assessment program within the CCOP framework was held during the meeting of the Working Group on Petroleum Geology which directly followed the Northwest Quadrant Panel Meeting.

W. 0. Addicott. 
Table 11

Open-File Report 85-267

Table 11. Report of the 1984 meeting of the Northwest Quadrant Panel, Bandung, Indonesia (manuscript for report of XXI CCOP Meeting, Nov-Dec 1984).

\section{Introduction}

The Tenth Session of the Northwest Quadrant Panel of the Circum-Pacific Map Project was held on December 3, 1984, at the Geological Research and Development Center, Bandung, Indonesia, concurrently with the Twenty-First Session of CCOP.

C. Nishiwaki, Chairman of the Northwest Quarant Panel, presided and W. 0 . Addicott was appointed reporter.

Participants in the meeting included representatives from Quadrant countries of China, Indonesia, Japan, Malaysia, Philippines, Republic of Korea, Thailand, and USSR. Observers from Australia, Canada, France, Netherlands, Papua New Guinea, United Kingdom, and USA were also in attendance.

General Chairman's Report

Forty-six map sheets have been authorized for publication by the Map Committee. The half way point in map production was expected to be reached by year-end 1984. Three complete series have been published: Base, Geographic, and PlateTectonic Map Series. The initial sheet in the Geological Map Series was printed in late 1983, the initial Geodynamic Map in mid-1984, and the first MineralResources Map was at the printers, with publication expected by mid-December of 1984. All five Plate-Tectonic Maps have been reprinted; the Pacific Basin Plate-Tectonic Map has been reprinted twice and was revised in 1984.

Targets for 1985 are publication of the entire Geologic and Geodynamic Series. Nine map sheets are scheduled for printing in 1985. Final cartographic corrections were being made on two Pacific Basin Maps: Manganese Nodule, Seafloor Sediment, and Sedimentation Rate and Tectonostratigraphic Terranes. Publication of these was expected in early 1985.

The Project cartographic staff of two full-time cartographers and two parttime cartographic technicians is being augmented in order to deal with the 14 map sheets currently under cartographic preparation at the Menlo Park and Reston offices of the U.S. Geological Survey.

Maps currently the focus of Panel compilation effort include the EnergyResources, Mineral-Resources, and Tectonic Maps. Most compilations are targeted for completion in 1985 and 1986. Publication of the entire 46-map series is scheduled to be completed during 1989.

The CPMP will convene a session of technical papers on Phase I maps at the IV Circum-Pacific Conference in Singapore, August 17-22, 1986. It will stage 
a special exhibit of all printed maps. Poster sessions on thematic maps still in preparation, including Phase II Southeast Asia Basin Evaluation maps, will also be held.

A revised CPMP information brochure, a one-page coloured map availability brochure, and a 1984 status report will all be issued by Project headquarters during the first half of 1985.

Major exhibits of published Circum-Pacific maps and color proofs were staged in Sydney, Moscow, Texas, and Nevada during 1984.

Panel Chairman Report

The first proof of the Geologic Map of the Northwest Quadrant, completed in June 1984, was exhibited. The necessity of further checking the position of geologic units in the area and coasts of USSR was noted; plans for completing this review by January 1985 were made. Extensive corrections were completed during October by $Y$. Teraoka in cooperation with $T$. Nozawa, both of the Geological Survey of Japan. The map is scheduled to be printed in mid-1985.

Significant contributions to the Tectonic Map of the Northwest Quarant were received from the USSR in February and from China in April and September. Problems in the overlap area with the Southwest Quadrant have been resolved. Final compilation of the Map by the Geological Survey of Japan is expected to be completed during the early part of 1985 .

The May 1984 color proof of the Geodynamic Map of the Northwest Quadrant has been thoroughly revised. A facsimile copy of the color proof was exhibited at the meeting. Prepared under the direction of G. W. Moore, the map was targeted for printing at year-end 1984 .

The geologic background for the Mineral-Resources Map of the Northwest Quadrant, derived from the Geologic Map, has been completed by M. Kamitani of the Geological Survey of Japan. Simplified elements from the Tectonic and PlateTectonic Map are included. Mineral deposit symbols of island-arc and continental-margin areas are being plotted, but deposits of continental Asia are still incomplete. A color proof of the marine minerals element, completed by $D . Z$. Piper and T. R. Swint in May, was displayed.

\section{Energy-Resources Map Compilation}

Chief compiler Inoue discussed and displayed a draft of the Northwest Quadrant Energy-Resources Map including oil and gas fields, coal deposits, geologic background, and sediment isopachs. Photocopies of the compilation were distributed to member-country representatives for updating. Corrections were requested by the end of January 1985. Simflar requests are being made to the Southwest and Northeast Quadrant Panels. Yet to be compiled are geothermal convection systems. 


\section{Circum-Pacific Council Executive Director's Comments}

J. A. Reinemund congratulated Chairman Nishiwaki on the work of the panel and acknowledged the significant role played by the Geological Survey of Japan in map compilation.

Plans for the 1986 CPCEMR Conference in Singapore were summarized. Continent to ocean cross section, an unrealized goal of the CPMP, involving cooperation between SEATAR and the Northwest Quadrant Panel, were recommended to the Panel with a target for display of preliminary results at the Conference. Another Conference objective is completion and display of preliminary drafts of some maps to be prepared for the Sedimentary Basin Resources Assessment Program.

The CPMP was seen as entering a new phase of compilation activity in which responsibility for map compilation will move from the Northwest Quadrant Panel to the individual countries. The Panel's role will involve receiving and reviewing map compilations and arranging cartography and printing with the help of the CPCEMR. It was recommended that existing cartographic capacities in the CCOP-region countries be enlisted in this effort and that CPCEMR move to support strengthening those capabilities where needed.

Meetings important in developing the Sedimentary Basin Assessment Program include a January 1985 meeting in Washington, D.C., on resource assessment techniques for the project, the Annual CPMP/CPCEMR meetings in Honolulu in June 1985 in which plans will be reviewed, the Kuala Lumpur petroleum resources assessment seminar in July 1985, and the mineral deposit modeling seminar in Manila in December 1985. Preliminary map products that develop as a consequence of these meetings will then be presented at the IV CircumPacific Conference in Singapore in August 1986. Formation of a steering committee involving representatives from participating organizations presumably will take place during the Kuala Lumpur meeting.

Matters discussed

It was recommended that ASCOPE be consulted in the preparation of sha1low water and coastal parts of the proposed SEATAR/CPMP cross sections.

It was suggested that a preliminary form of publication be instituted for initial map products of the sedimentary basin resources assessment study. Use of initial ozalid-type reproduction was recommended to accelerate map production as an alternative to the slower CPMP full-color map series.

The possibility of preparing indexes to geologic and resource maps of the Northwest Qudrant was recommended to the panel for consideration. 
Table 11, pg. 4

Open-File Report 85-267

Schedule for Printing Circum-Pacific Thematic Maps

Map Sheet

*Northeast Plate-Tectonic Map

* Southeast Plate-Tectonic Map

*Antarctica Plate-Tectonic Map

* Southwest Plate-Tectonic Map

*Northwest Plate-Tectonic Map

*Pacific Basin Plate-Tectonic Map

*NE Geologic Map

*SE Geologic Map

* SW Geologic Map

*NW Geologic Map

*Antarctica Geologic Map

*SW Tectonic Map

*SE Tectonic Map

*NW Tectonic Map

*NE Tectonic Map

*Antarctica Tectonic Map

*NE Geodynamic Map

*NW Geodynamic Map

*SW Geodynamic Map

*SE Geodynamic Map

*Antarctica Geodynamic Map

*Pacific Basin Geodynamic Map

*NE Energy Resources Map

*SE Energy Resources Map

*SW Energy Resources Map

*NW Energy Resources Map

*NE Mineral Resources Map

*SE Mineral Resources Map

*SW Mineral Resources Map

*NW Mineral Resources Map

*Antarctica Mineral Resources Map

Pacific Basin Manganese Map

*Pacific Basin Tectonostratigraphic Terrane Map

Pacific Basin Geology and Resources Map
Printing Target

1981

1981

1981

1981

1981

1982

1983

1985

1985

1985

1985

1986

1987

1986

1988

1988

1984

1985

1985

1985

1985

1985

1986

1986

1986

1987

1984

1986

1987

1987

1988

1985

1985

1989

* To be accompanied by an explanatory notes booklet (only one booklet to be issued for the Plate-Tectonic and Geodynamic Map Series). 
Table 11, pg. 5

Open-File Report 85-267

List of Participants at Northwest Quadrant Panel Meeting, Bandung, Indonesia

CHINA

Yang Chiling

Zhang Ruiyiang

He Qixiang

Li Zhijian

INDONES IA

H.M.S. Hartono

M. Untung

M. Thamrin

Ismail Usna

Soebardjio Tjokrosapoetro

Wikarno

Suharsono

Silitonga

JAPAN

Eij1 Inoue

Chikao Nishiwaki

Nobuyoshi Fujioka

Jiro Hirayama

REPUBLIC OF KOREA

Chong Su Kim

Cho Kyu Jang

MALAYSIA

Yin Ee Heng

K. Thavapragasam

T. Suntaralingham

PAPUA NEW GUINEA

Richard Rogerson

PHILIP PINES

Guillermo R. Balce

THAILAND

Sermsakdi Kulvanich
CANADA

Bernard F. Manistre

FRANCE

Maurice Mainguy

NETHERLANDS

Erno Oele

USSR

Mikhail N. Alekseev

Nicolai V. Tchoulkov

UNITED KINGDOM

Clive R. Jones

USA

Warren 0. Addicott

William R. Greenwood

Dennis E. Hayes

John A. Reinemund

George G. Shor, Jr.

Maurice J. Terman

ESCAP

Lawrence F. Machesky

CCOP

S. K. Chung

E. P. DuBois

Richard Reid

John Ring is

J.A.M. Ten Cate 
Table 12. Notes from 1984 Antarctica Panel meeting, Moscow, USSR.

The meeting was held at $6: 00 \mathrm{pm}$ on August 8 in the Sovincentr, Moscow, USSR. Those present were K. Birkenmajer (Poland), G. Grikurov (USSR), E. Grew (USA), J. Hofmann (GDR), E. N. Kamenev (USSR), and C. Craddock (USA), chairman of the Antarctica Region panel.

Craddock reported on Antarctic map sheets of the Circum-Pacific Map Project, including the new Base Map (1985), the second edition of the Plate-Tectonic Map (1983), the Geodynamic Map (1985), the Geologic Map (1985), and the Tectonic Map (in preparation). It was asked whether the new base had been used for the second edition of the Plate-Tectonic Map; Craddock replied that it had been necessary to use the original, rather distorted base again.

Grikurov stated that a new Soviet Antarctic Atlas is in preparation, and it will include about 30 pages of maps on geology, tectonics, metallogeny, bedrock relief, gravity, and magnetics. Maps of the entire continent will be at $1: 10,000,000-$ scale, and there will be 1:2,500,000-scale maps of the Lambert Glacier area and the Weddell Sea area. The geophysical maps are completed, and the others may be compiled by the end of 1984. The atlas may not be published for 5-7 years, but the Ministry of Geology might release the geologic/geophysical maps for earlier separate sale if requested to do so by CGMW.

Birkenmajer reported that a geologic map of the King George Island area is being compiled, and publication at 1:75,000-scale or 1:100,000-scale is expected within five years.

Hofmann said that a 1:25,000-scale geologic map of Schirmacher 0asis will be published soon with a monograph.

Grew reported that E. Stump was supervising the preparation of several 1:250,000-scale geologic maps of parts of northern Victoria Land.

Japanese workers have been issuing a series of large-scale geologic maps of outcrop areas in coastal East Antarctica.

Craddock reported that a combined Antarctic Mineral and Energy Resources Map is being planned by the Circum-Pacific Map Project. No other planned maps were described by those present.

The chairman asked whether there was a need to begin now on any other Antarctic map projects, particularly for the entire continent. Participants felt that completion of the current projects would provide satisfactory coverage of Antarctica for the immediate future. One barrier to improved geologic and tectonic maps is the scarcity of reliable radiometric-age determinations, especially in East Antarctica. It was suggested that the status of maps of the entire continent might be discussed again at the Gondwana symposium in 1985, the SCAR meeting in 1986, and/or the SCAR Antarctic symposium in 1987.

C. Craddock 
Table 13. Notes from the 1984 Southwest Quadrant Panel Meeting, Apia, Western Samoa.

The Southwest Quadrant Panel Meeting was scheduled for the evening of 31 October 1984, following one of the daytime Technical Advisory Group (TAG) meetings of the 13th Session of CCOP/SOPAC in Apia, Western Samoa. This Session, more so than previous ones, encouraged caucussing and ad hoc meetings. As a result, a number of last-minute meetings arranged concurrent with the scheduled Panel Meeting were, of necessity, attended by nearly all Panel Members, most of whom are chiefs or senior officers of SOPAC member-country geological surveys. The Panel Meeting was declared postponed, handouts prepared for it distributed later, and the maps to be discussed put on general display.

The same problem occurred every evening, so the Panel Chairman did not reconvene the Panel Meeting but took full advantage of the inclusion of the Map Project as a business item on the TAG agenca; the section of the TAG report on this item is attached. The expression of regret therein by the Papua New Guinea delegate about the fate of the Panel Meeting was backed strongy by the Tonga delegate, and agreed with by most others. The next SOPAC Session seems bound to feature the Panel Meeting as one of its essential it ems.

Overall, then, matters turned out well for the Map Project, as there was a large captive audience at the TAG meeting (including CPMP Scientific Coordinator M. J. Terman and Circum-Pacific Council Treasurer H. Gary Greene). Subsequent discussion of project detail with individuals took place in a fairly sympathetic atmosphere.

To be realistic, presentations to the TAG of CPMP, together with private ad hoc discussions would appear to be the best way of publicizing Map Project work in the area and pursuing its business in the future. The TAG meeting is undoubtedly the best forum available each year for exploring the mutual interests of the Project and Quadrant countries, and locally reporting the outcome.

H. F. Doutch

Excerpt from the 1984 CCOP/SOPAC TAG Report

The Circum-Pacific Map Project (CPMP) Southwest Quadrant Panel Chairman thanked SOPAC Technical Secretariat for including the map project on the TAG agenda. He briefly reported on the 4 th Annual Quadrant Panel Meeting held during the 12th Session of CCOP/SOPAC in Suva in 1983, and on project progress since then. Southwest Quadrant 1:10,000,000-scale Phase I maps nearest to completion are the Geodynamics Maps, which will probably be printed before the end of 1984, the Geologic Map expected to be printed by mid 1984, and the Tectonic Map, which should be published before the Circum-Pacific Council Concil Conference in Singapore in 1986. The quadrant Mineral and Energy Resources Maps are fairly well advanced. 
He pointed out that CPMP maps related directly to CCOP/SOPAC's regional program, and provide broader synthesis than, and different analyses to, those being prepared by CCOP/SOPAC. CPMP is already considering Phase II projects, and would be happy to cooperate with CCOP/SOPAC in the development of maps or map series of mutual benefit.

The meeting of CPMP during the 13th Session had to be postponed due to concurrent meetins but much useful informal discussion did go ahead. The PNG representative expressed regret and hoped the project will be given better consideration in future. 
Table 14. Notes from the 1984 Southeast Quadrant Panel Meeting, Santiago, Chile.

The Southeast Quadrant Panel met in Santiago, Chile, January 23-25, 1984. Panel Chairman José Corvalán welcomed representatives from all of the Andean countries except Ecuador and Venezuela, who were not represented.

Map Project General Chairman, Warren 0. Addicott, read a letter from Circum-Pacific Council Chairman Michel T. Halbouty outlining Council functions and welcoming the participants to the meeting. Addicott reviewed the goals, structure, history, and status of the Map Project. He later gave a resume of Circum-Pacific Council activities and history.

Corvalán pointed out that compilation of the Geologic Map began during 1973, with the cooperation of panel members from South American countries. Coples of the just-completed color proof of the Southeast Geologic Map were given to panel members with the request that they be checked, edited, and returned before the end of March. Panel member Marcelo Yrigoyen of Argentina indicated that corrections would be minor for his country. Carlos Ulriksen said that a March 1983 map of Chile should be checked against the color proof. Carlos Salinas of Bolivia noted that a 1:1,000,000-scale map of his country is now available and said that he would check it against the Southeast map. No major changes for Colombia were anticipated, according to Hermann Duque-Caro, who noted that an October 1983 terrane map of Colombia might be useful in checking the proof. Victor Eyzaguirre of Peru stated that the Peruvian part of the proof was up to date and no additions were indicated. He also called for an explanation of the method of compilation of the map beyond the brief paragraph now included on the face of the map. With regard to the 1:17,000,000-scale Pacific Basin Map, considered but not yet approved by the Map Committee, Addicott called attention to Corvalan's offer to prepare a sample compilation of South America for consideration at the 1984 Map Committee meeting. Corvalán requested that the panel members attempt to compile their countries at the $1: 17,000,000$ scale and said that he will then attempt to tie the geology together for the entire continent.

A discussion of panel membership brought out names of people who were no longer active in the field and who should be replaced. Corvalán noted that Fernando Etayo of Colombia had been asked to participate as a panel member but was unable to attend the meeting. Addicott promised that headquarters would conclude efforts to identify a new member from Venezuela shortly after the meeting.

Corvalán said that the Mineral Resources Map compilation is complete and said that it was displayed at the 1983 Panel Chairmen's meeting in Honolulu. He noted that the geologic background for South America is somewhat different from that of the Northeast Quadrant Map, especially in the southern part, where euliminar and mioliminar facies are mapped. Moreover, the background focuses more on ages than does the Northeast Quadrant background. Compilation 
for this map was at 1:5,000,000 scale which was then reduced to $1: 10,000,000$. Age of mineralization is known for a majority, but not all, of the deposits. Each deposit is numbered and keyed to data that will be included in the booklet.

Panel members informed the meeting of the status of mineral mapping and data assembly for their countries. Corvalán set June as the target for recompilation of the Southeast Mineral-Resources Map. He requested that colored copies of the Southeast Map be made at headquarters and distributed to panel members for checking and additional information.

The Energy-Resources Map proof was displayed. Corvalán remarked that the sedimentary bàsin depiction needed improvement and asked the help of all panel members in this effort. He said that Gordon Wood's list and map of coal fields would be sent to each panel member for checking and additions. Yrigoyen recommended use of AAPG's classification of oil and gas fields. One participant questioned the symbology for oil fields, especially the suggested use of a large filled circle for small fields, noting the possible confusion with a field of similar size and shape. Yrigoyen was appointed editor of this thematic map.

Addicott reviewed the guidelines and status of compilation of the Tectonic Map Series. Corvalán noted that the Southeast Map has incorporated the latest information from the Tectonic Map of South America by Martín, as well as direct contributions from various South American countries. Corvalán asked panel members to check copies of his preliminary map and respond. Corvalán also noted that there are basically three structural units in the Andean belt--north, central, and south--which may require special symbology for depiction. Updating of the Tectonic Map will be completed by the end of March and copies sent to the panel members. Returns were requested by the end of May. Panel members noted that this map is extremely complicated and probably difficult to understand by a person not closely familiar with tectonics and the map guidelines.

Addicott reviewed plans for compilation and review of the Geodynamic Map Series, which is being compiled under the guidance of George W. Moore, editor of this map series. Proofs of three Geodynamic Maps are expected to be completed by June 1984. A request was made for information on active faults of the Andean belt.

Chairman Corvalán summarized the status of map compilation work in the Southeast Quadrant, noting that the project is active and that significant progress is being made toward completing all of the maps. He acknowledged the participation of new panel members and congratulated the long-standing members for their contributions. Corvalán noted that the panel representatives will have the responsibility of bringing together specialists to meet specific compilation needs and, as such, will serve as coordinators of work in their countries. 
Table 14, pg. 3

Open-File Report 85-267

Carlos del Solar noted the Circum-Pacific Council's support of this meeting and maintained that future meetings should be moved to different countries to maximize participation in this work. Eyzaguirre proposed that the next meeting be held in Lima, Peru. The panel members endorsed the proposal.

W. 0. Addicott. 
Table 14, pg. 4

Open-File Report 85-267

Participants in the 1984

Southeast Panel Meeting at Santiago, Chile

Addicott, Warren 0 .

U.S. Geological Survey

345 Middlefield Road, MS 952

Menlo Park, California, U.S.A. 94052

Corvalán D., José

University of Chile

Department of Geology and Geophysics

Casilla 13518

Santiago, Chile

Del Solar, Carlos

Occidental Petroleum

Los Nardos 1018

Lima 27, Perú

Duque-Caro, Hermann

Ingeominas

Diagonal 53 no. 34-53

(Ap. Aereo 4865)

Bogota, Colombia

Eyzaguirre, Victor R.

Mauricio Hochschild Ltd.

Av. Republica de Panama 3055

Casilla 849, Piso 13, San Isidro

Lima, Perú

Fuenzalida Ponce, Ricardo

Noranda Exploraciones Chile Ltd.

Felix de Amesti 350

Santiago, Chile

Gajardo C., Anibal

University of Chile

Department of Geology and Geophysics

Plaza Ercilla 803

Casilla 13518, Correo 21

Santiago, Chile

Gonzales Pacheco, Eduardo

Empresa Nacional del Petroleo

Ahumada $341-6^{\circ}$ Piso

Casilla 3556

Santiago, Chile
Henriquez Amato, Hugo

University of Chile

Department of Geology and Geophysics

Plaza Ercilla 803

Casilla 13518

Santiago, Chile

Lahsen P., A.

University of Chile

Department of Geology and Geophysics

Plaza Ercilla 803

Casilla 13518

Santiago, Chile

Langerfeldt, Hans

Empreso Minera Mantos Blancos

Casilla 153-D

Santiago, Chile

Lorca Mella, Emilio

Instituto Hidrográfica de la Armada

Correo Naval

Valparaiso, Chile

Martinez Pardo, Ruben

University of Chile

Department of Geology and Geophysics

Plaza Ercilla 803

Casilla 13518, Correo 21

Santiago, Chile

Morales Gamboa, Esteban

Universidad Catolica de Valparaiso

Av. Brasil 2950

Valparaiso, Chile

Oraze F., Mauricio

Universidad de Chile

Department of Geology and Geophysics

Plaza Ercilla 803

Casilla 13518, Correo 21

Santiago, Chile 
Table 14, pg. 5

Open-File Report 85-267

Parada, Miguel Angel

University of Chile

Department of Geology and Geophysics

Plaza Ercilla 803

Casilla 13518, Correo 21

Santiago, Chile

Salinas Estenssoro, Carlos

Occidental Boliviana, Inc.

Casilla 1296

Telex 5625, Oxybol-bx

Santa Cruz, Bolivia

Ulriksen G., Carlos

Servicio Nacional de Geología y Minería

Sub-dirección Geología

Agustinas 785

Piso $6^{\circ}$, Casilla 10465

Santiago, Chile

Varela B., Juan

University of Chile

Department of Geology and Geophysics

Plaza Ercilla 803

Casilla 13518, Correo 21

Santiago, Chile

Yrigoyen, Marcelo R.

Esso Exploration Inc.

Della Paolera 297 - $5^{\circ}$

1001 Buenos Aires, Argentina 
Table 15. Notes from the 1983 Northeast Quadrant Panel Meeting, Indianapolis, Indiana.

A meeting of the Northeast Quadrant panel was held at 11:00 am, November 1, 1983, in Indianapolis, Indiana, in conjunction with the 1983 GSA Annual Meeting. In attendance were:

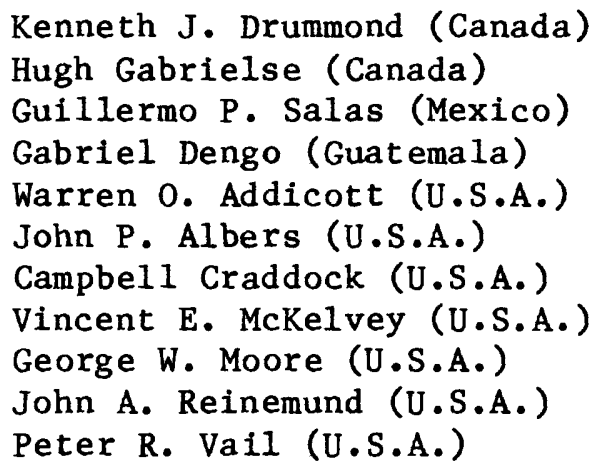

Addicott reviewed the overall objectives and status of the map project. With the publication of the complete Plate-Tectonic series, more attention has been focused on the remaining map series. The schedule calls for publication of from four to six maps each year. Addicott pointed out that the Northwest and Southwest panels have had yearly quadrant meetings, whereas the Northeast and Southeast have not. It is for this reason, and in particular to increase the involvement of panel members and to develop more participation by Central American countries, that this meeting was convened.

Panel Chairman Drummond reviewed the overall status of the various thematic maps for the Northeast Quadrant to November 1, 1983. The Plate-Tectonic Map was published in 1981 (press run, 1,500 copies) and a second printing was made in 1982 (1,000 copies). The Geologic Map was printed on October 25, 1983 (1,500 copies) and was displayed at the Circum-Pacific Map Project exhibit at the GSA meeting. Copies of the map were distributed to panel members present. The Minera1Resources Map was in final proof stage and was scheduled for publication in 1984. A preliminary version of the Energy-Resources Map was printed in proof copy in 1978. Updating and all compilation should be completed in 1983. Work on the explanatory text, which will include tabular data and cross sections, has begun. Vail indicated he could provide assistance with tabulated data for the text. Plans call for a proof copy, with the explanatory booklet to be completed in March 1984.

George Moore is directing the compilation of the Geodynamic Map for all quadrants and Antarctica. For the Northeast Quadrant, most of the elements have been assembled, and compilation is ready to proceed. Plans call for a proof in time for discussion at the mid-1984 Panel Chairmen's Meeting in Honolulu.

Compilation of the Tectonic Map has not yet begun. Basic line work is available from the Geologic and Plate-Tectonic Maps and older preliminary versions. With the help of Moore, Drummond will put together a draft version for discussion at 
Table 15, pg. 2

Open-File Report 85-267

the 1984 Honolulu meeting. Salas gave the Panel Chairman a series of tectonic element maps of Mexico (at 1:10,000,000 and 1:2,000,000 scale). These included: (1) map of major rock units, (2) Landsat lineation map, (3) structural features, and (4) Landsat photo-mosaic of Mexico.

In summary, by the next Panel Chairmen's meeting in Honolulu in June 1984, the Northeast Panel should be at the following stage: three maps published (PlateTectonic, Geologic, Mineral-Resources), two maps in proof (Energy Resources and Geodynamic), and one map in preliminary draft copy (Tectonic).

John Albers reviewed his 1:10,000,000-scale mineral deposit and terrane map of the Northeast Quadrant. A new map compilation showing all terranes with major occurrences should be done by next year, according to Albers.

John Reinemund reviewed the status of special basin-wide maps. Compilation of the bottom sediment and sea bed manganese nodule map is complete and ready to proceed towards publication. A new revised map of the accretionary terranes of the Circum-Pacific by David Howell and others will likely be submitted for consideration at the June 1984 meeting. Reinemund then moved on to discussions with Dengo and Salas concerning greater involvement in Northeast Quadrant Panel work by Central American countries. Dengo supplied Reinemund with a list of names from several countries. Reinemund and Addicott will contact these individuals for possible addition to the Northeast Panel.

It was suggested by Reinemund that a regular meeting of the Northeast panel be scheduled in the fall of each year. He recommended that a meeting be held in Mexico in October 1984 (the meeting was later rescheduled for February 18 and 19, 1985). Dengo and Salas endorsed this suggestion and Salas will investigate the feasibility of holding the meeting in Mexico.

K. J. Drummond. 


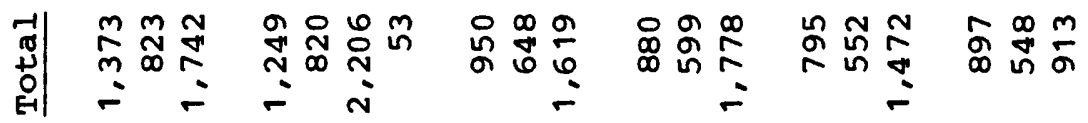

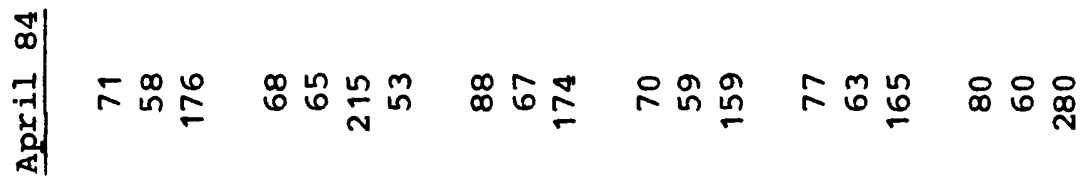

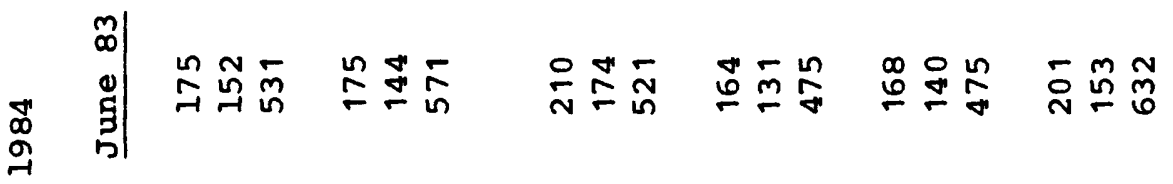

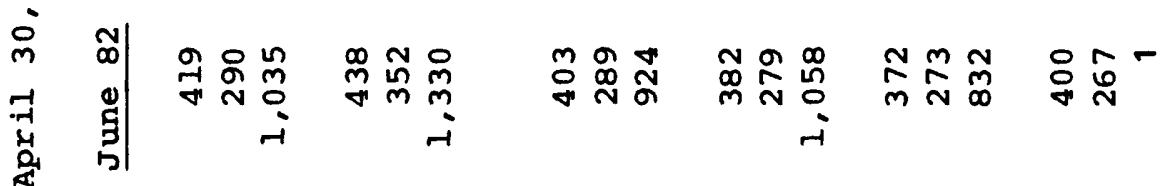

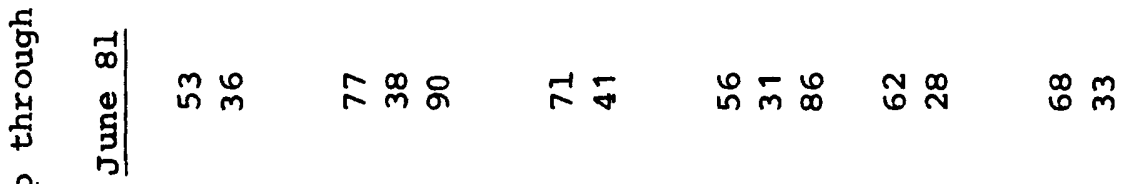

这

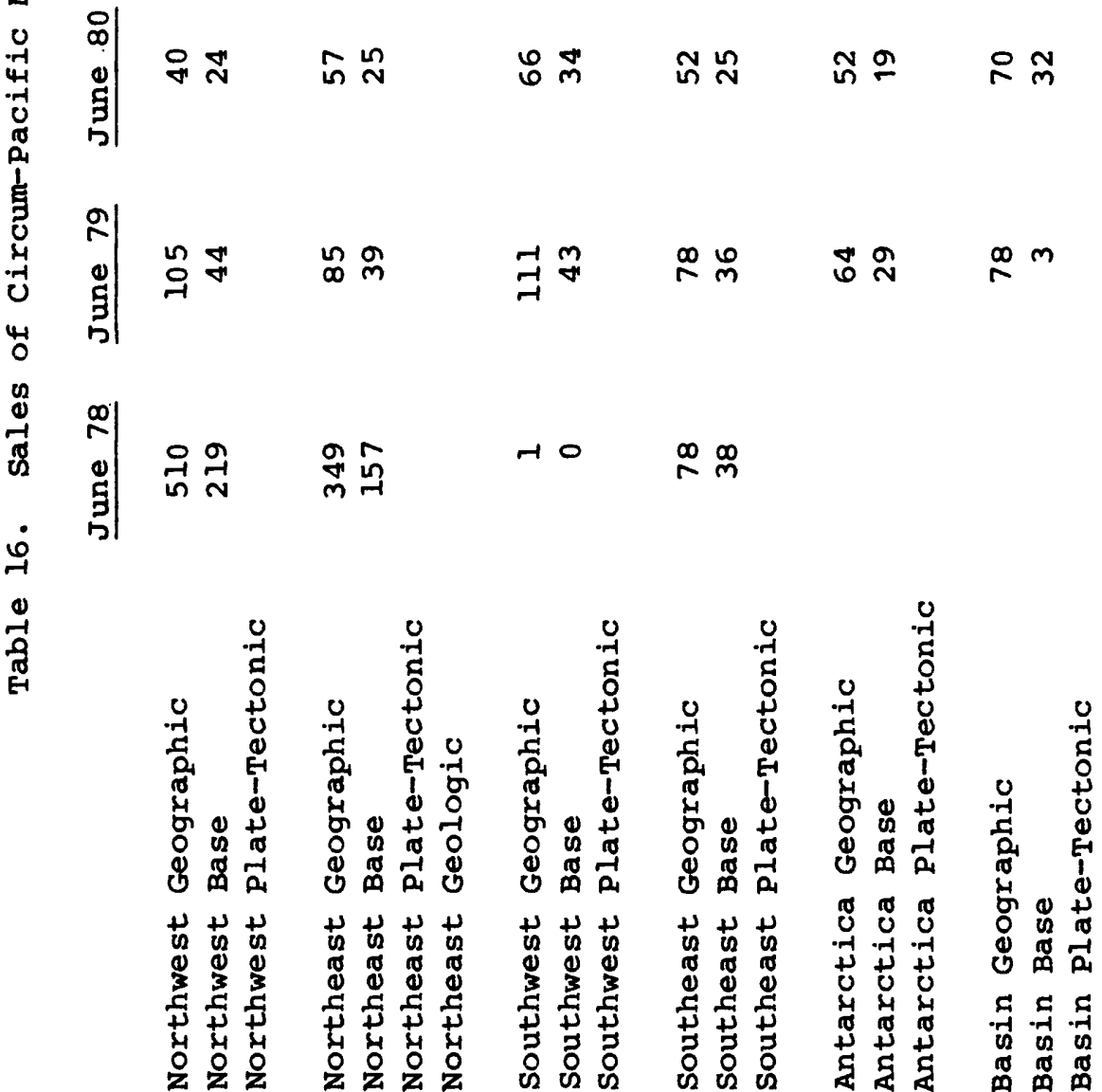


Table 17. Modification of compilation guidelines for the Mineral-Resources Map of the Southwest quadrant recommended by the southwest Quadrant Panel.

Problems with CPMP "deposit types" classification

The main problem with the proposed CPMP "deposit type" classification is the random mixture of the two parameters, morphology and genesis, in defining the eight categories. The genetic part of this classification is indicated in red brackets below:

\author{
Deposit type. Shown by tick(s) on basic symbol. \\ Veins and shear-zone fillings \\ - Stratabound, including magmatic cumulates \\ a stockworks, including "porphyry" deposits \\ \. Magmatic and irregular massive deposits \\ - Skarn or greisen deposits \\ O- Sandstone (red bed) deposits \\ $\checkmark \quad$ Laterite deposits (surficial chemical concentrations) \\ Placer deposits (surficial mechanical concentrations)
}

Initially, I gather from early CPMP reports, the classification was to be based only on form (or morphology) of deposit. The presently proposed CPMP deposit type classification seems half-baked and also ill-suited for many Australian deposits, i) such as the stratiform type; ii) there is of ten overlap between vein and stockwork deposits, so these should be grouped together; iii) by including magmatic cumulates in the stratabound category, they are mixing Bushveld type deposits with Mississippi valley and -type stratabound deposits; this is unsatisfactory as they are quite dissimilar in other more important aspects. Magmatic cumulates as such should be included in the "magmatic" category; iv) it is unclear where volcanic deposits fit into the classification. They could in part be slotted into the "magmatic" category, but this isn't the best solution, as it is important to distinguish plutonic versus volcanogenic mineral deposits; v) pegmatites don't clearly fit into any of the CPMP categories, unless it is presumed they fit into the "magmatic" category; vi) greisens are more suited to the "porphyry-type" category, than to the "skarn" category; vii) the sandstone (red-bed) category is very simplistic as it associates the red color to a state of oxidation. This is misleading, as for example in the case of "red-bed $\mathrm{Cu}$ " deposits the $\mathrm{Cu}$ deposit itself formed within a cyclic oxidation. This is misleading, as for example in the case of "red-bed Cu" deposits the $\mathrm{Cu}$ deposit itself formed within reduced beds within a cyclic 
oxidizing/reducing environment; viii) "laterite" deposits are only one form of surficial chemical concentrations. Dissolution and reprecipitation type deposits, e.g., opals and precious metal gossans, should be included in this category.

I have given below significant Australian mineral resource examples for each of the proposed CPMP categories.

\section{CPMP Proposal}

\begin{tabular}{|c|c|c|c|c|}
\hline $\begin{array}{l}1 \\
\underline{5}, 6\end{array}$ & $\begin{array}{l}0 \\
-0\end{array}$ & $\begin{array}{l}a \\
b\end{array}$ & $\begin{array}{l}\text { Veins and shear-zone fillings } \\
\text { stratabound, including magmatic } \\
\text { cumulates }\end{array}$ & $\begin{array}{l}\text { Norseman Au (W.A.) } \\
\text { Mt. Gunson Cu (S.A.); } \\
\text { Ccobina Chromite (W.A.) } \\
\text { [Bushveld-type magmatic } \\
\text { cumulate] }\end{array}$ \\
\hline 1,2 & $Q$ & c & $\begin{array}{l}\text { Stockworks, including "porphyry" } \\
\text { deposits }\end{array}$ & $\begin{array}{l}\text { Mt. Carbine } w \text { in qtz veins } \\
\text { (old.)-[Stockworks]; } \\
\text { Parkes Cu (NSW)-"porphy- } \\
\text { ry" }\end{array}$ \\
\hline 6 & $\mathfrak{d}$ & d & $\begin{array}{l}\text { Magmatic and irregular massive } \\
\text { deposits }\end{array}$ & $\begin{array}{l}\text { Kambalda Ni Cu PGE (W.A.)- } \\
\text { [magmatic]; Carr Boyd } \\
\text { Rocks Ni Cu (W.A.)-[ir- } \\
\text { regular massive] }\end{array}$ \\
\hline 3,2 & $-\phi$ & e & Skarn or greisen deposits & $\begin{array}{l}\text { King Is. W (Tas)-[skarn]; } \\
\text { Elsmore Sn (NSW)-[grei- } \\
\text { sen] }\end{array}$ \\
\hline 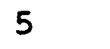 & $\mathrm{O}^{-}$ & f & Sandstone (red bed) deposits & Honeymoon U (S.A.) \\
\hline 7 & $\sigma$ & $g$ & $\begin{array}{l}\text { Laterite deposits (surficial } \\
\text { chemical concentrations) }\end{array}$ & Weipa bauxite (Qld.) \\
\hline 8 & O & h & $\begin{array}{l}\text { Placer deposits (surficial } \\
\text { mechanical concentrations) }\end{array}$ & $\begin{array}{l}\text { Ravenshoe Tableland Sn } \\
\text { (Qld.) }\end{array}$ \\
\hline
\end{tabular}

Alternative "deposit type" classifications

A systematic genetic classification that does justice to mineral deposit types in the Australian region has been proposed by Perkin and Chan. A condensed summary of this classification is given below. This classification gives a much clearer understanding of the deposit type, especially if a more detailed description is included in the legend of the minerals map, and overcomes the main problems inherent in the CPMP proposed classification. As this classification has a genetic basis, however, it is open to interpretation based on current models of ore genesis. For this reason and the fact that the southwest quadrant should 


\section{Genetic Proposal}

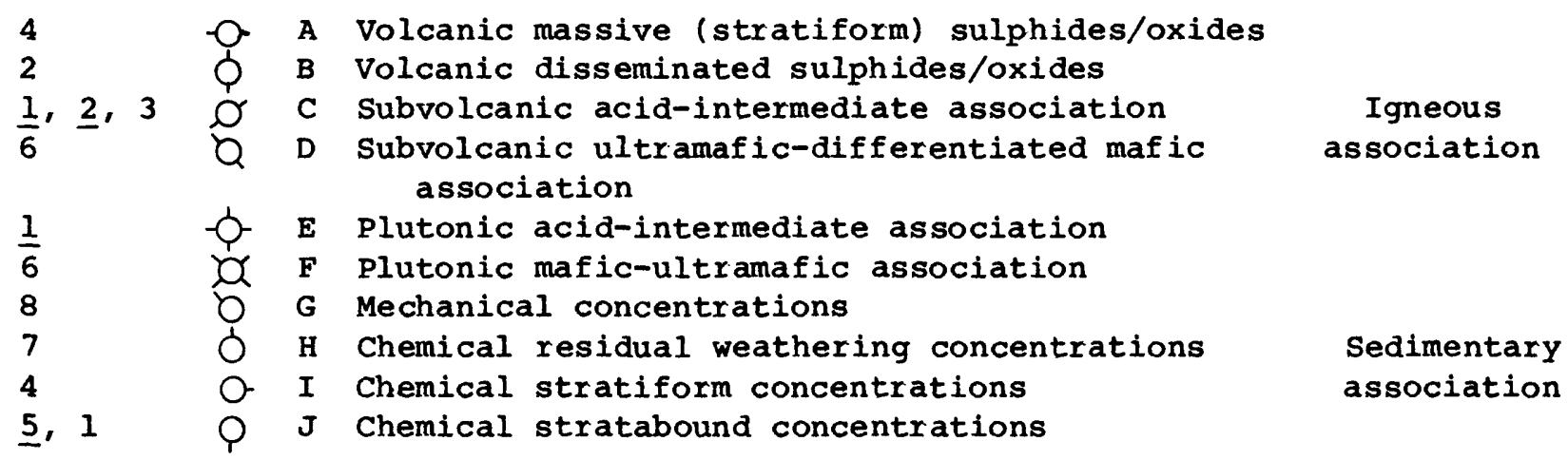

blend in with the other quadrants of the Circum-Pacific (i.e., same number of categories, same symbolization, similar categories), Perkin and Chan have proposed a compromise classification (see below). This classification overcomes the main specific objections ( $i$ to viii) to the CPMP proposed classification; however, it does not overcome the general objection of a morphology/genesis hotchpotch (c.f. apples/pears).

Compromise Proposal by Perkin and Chan

$\mathrm{a}, \mathrm{c} ; \underline{\mathrm{C}}, \underline{\mathrm{E}}, \mathrm{J}$
$\mathrm{C}$
$\mathrm{e}, \mathrm{C}, \mathrm{C}$
$\mathrm{B} ; \mathrm{A}, \mathrm{I}$
$\mathrm{b}, \mathrm{f} ; \mathrm{J}$
$\mathrm{d}, \mathrm{b} ; \mathrm{D}, \mathrm{E}$
$\mathrm{g} ; \mathrm{H}$
$\mathrm{h} ; \mathrm{G}$

1 Stockworks, veins, shear-zone fillings

2 Large disseminated porphyry-type, including greisen deposits

3 Skarn deposits

4 Stratiform massive deposits (sedimentary \& volcanogenic)

5 *Stratabound deposits (sedimentary \& volcanogenic)

6 Magmatic deposits, including pegmatites

7 Residual weathering concentrations

8 Placer deposits

* Includes so-called "sandstone (red-bed)" deposits of CPMP clasification

$\checkmark$ Includes "magmatic cumulates" of CPMP classification

Cross-correlations between "deposit type" classifications

Cross-correlations have made between deposit types a to $h$ of the CPMP proposal and deposit types 1 to 8 of the compromise proposal (in blue). Cross-correlations have also beenmade between deposit types $A$ to $J$ of the genetic proposal and deposit types 1 to 8 of the compromise proposal (in red). The dominant component is underlined.

Over the page I have prepared a matrix which cross-correlates the three classifications using the significant Australian mineral resource examples mentioned previously plus a few extra examples. 
Table 17, pg. 4

Open-File Report 85-267

Example

\begin{tabular}{|c|c|c|c|c|}
\hline & CPMP & Genetic & Compromise & \\
\hline Norseman $\mathrm{Au}$ (W.A.) & $\mathbf{a}$ & $\mathrm{J}$ & 1 & \\
\hline Mt. Gunson $\mathrm{Cu}$ (S.A.) & b & $\mathrm{J}$ & 5 & \\
\hline Coobina Chromite (W.A.) & $\mathrm{b}$ & $\mathbf{F}$ & 6 & \\
\hline Mt. Carbine $w$ in $q t z$, veins (Qld.) & c & $\mathbf{E}$ & 1 & \\
\hline Parkes $\mathrm{Cu}$ (N.S.W.) & c & C & 2 & \\
\hline Kambalda Ni Cu PGE (W.A.) & $\mathrm{a}$ & A & 6 & \\
\hline Carx Boyd Rocks Ni Cu (W.A.) & $\mathrm{a}$ & D & 6 & \\
\hline King Is. W (W.A.) & e & C & 3 & \\
\hline Elsmore Sn (N.S.W.) & e & $\mathrm{C}$ & 2 & \\
\hline Honeymoon U (S.A.) & $\mathbf{f}$ & $\mathrm{J}$ & 5 & \\
\hline Weipa Bauxite (Qld.) & g & н & 7 & \\
\hline Ravenshoe Tableland Sn (Qld.) & $\mathrm{h}$ & G & 8 & \\
\hline Woodlawn $\mathrm{Cu} \mathrm{Pb} \mathrm{Zn}$ (N.S.W.) & - & A & 4 & \\
\hline Greenbushes $\mathrm{Sn} \mathrm{Ta}$ (W.A.) & - & $\mathbf{E}$ & 6 & Extra \\
\hline Argyle Diamond (W.A.) & $\mathrm{a}$ & $\mathrm{B}$ & 5 & examples \\
\hline Mt. Isa $\mathrm{Pb} \mathrm{Zn}$ (Qld.) & $\mathrm{b}$ & I & 4 & \\
\hline
\end{tabular}

The extra examples of Woodlawn and Greenbushes indicate there is no suitable category in the CPMP classification for stratiform and pegmatite deposits to slot into. Possibly the Americans don't recognize stratiform deposits as such, and so lump these deposits into their stratabound category. This is most unsatisfactory. The Argyle deposit is mentioned because this is another deposit type that is lumped into category ' $d$ ' of the CPMP classification, along with Kambalda and Carr Boyd Rocks - type deposits, and which is differentiated in the 'genetic' and 'compromise' classifications. The same applies to the Mt. Isa $\mathrm{Pb} \mathrm{Zn}$ example, which is lumped with Mt. Gunson and Coobina-type deposits into category ' $b$ ' of the CPMP classification.

In conclusion, the proposed "genetic" classification is the more satisfactory, systematic and specific classification of the three proposals. However, it may in part be subject to interpretation, and it could result in inconsistencies with the other Circum-Pacific quadrants. For these reasons I would advocate the "compromise" classification as a suitable classification to follow for the Southwest Quadrant mineral resources deposit types.

\section{Age of Mineralization}

The age of mineralization categories suggested by the CPMP mineral resouxces committee (see below) heavily favors younger deposits. As many Australian deposits are of Proterozoic or Archean age, and keeping in mind a limit of eight categories of symbolizations, Perkin and Chan have proposed a more appropriate classification for the Australian region (see below). The suggestion that the CPMP classification be retained with the modification of adding $A$, EB, MB, LB to category "1" symbolization may prove cumbersome. However, for the sake of consistency with other quadrants, this may prove a suitable compromise. 
Age of Mineralization (CPMP)

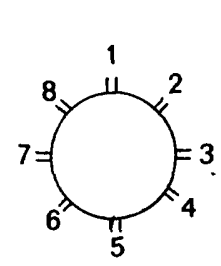

1. Precambrian

2. Cambrian-Middle Devonian

3. Late Devonian-Early Triassic

4. Middle Triassic-Jurassic

5. Cretaceous (except latest)

6. Latest Cretaceous-Eocene (Laramide)

7. Oligocene-Pliocene

8. Post-Tertiary

Age of Mineralization (Perkin, Chan)

1. Archaean

2. Early Proterozoic

3. Middle Proterozoic

4. Late Proterozoic

5. Cambrian-Middle Devonian

6. Late Devonian-Cretaceous

7. Tertiary

8. Quaternary

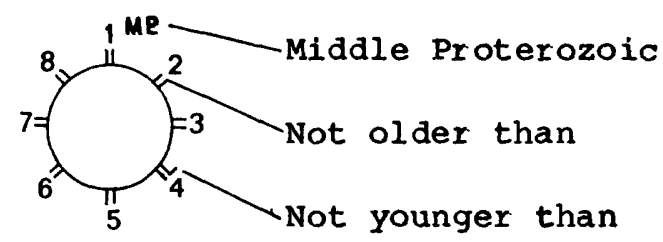

P.S. It is unclear whether the time categories suggested for age of mineralization should apply to age of host rocks as well.

Roslyn Chan 9-13-84 
Table 18. Compilation guidelines for the Tectonic Map series.

\section{INTRODUCTION}

These guidelines were perfected in 1982 as a result of several years of preparation and refinement. They are based upon a draft developed by a committee composed of M. J. Terman, H. F. Doutch, E. Scheibner, and G. W. Moore.

STRUCTURAL AND TECTONIC FEATURES (in black except as indicated)

Plate boundaries and spreading centers: as on Plate-Tectonic Map.

Folds: Anticlinal axis

(gentle and open)

Selected synclinal axis
Anticlinal axis

(tight and closed)

Numerous folds

Faults, fracture zone: extend from Geologic Map to include all faults; show displacement where known.

\section{Normal \\ (dip slip)}

Reverse

(high angle)

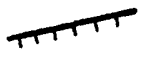

)

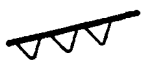

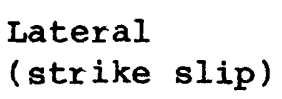

Buried
Thrust

(low angle)

Historic (red): displacement has occurred within the past 2000 years and is associated with recorded earthquakes or creep.

Post-Miocene (orange): displacement not associated with historic records, but recognized by scarps or water barriexs in post-Miocene sediments, markedly linear mountain fronts, offset streams, or alignment of fault-caused depressions; entire fault should be shown in orange where local evidence indicates post-Miocene age.

Pre-Pliocene or unknown (black).

Volcanoes (to be recompiled by Smithsonian Institution, and added to the map at project headquarters):

Dikes (if thought necessary): thin line with dots, all in green. If desired, annotate with lithologic term, abbreviated; e.g., dol $(=$ dolerite $)$.

Areas of salt domes:

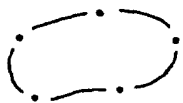

Diatremes, cryptoexplosion structures, kimberlite pipes, lamproites, and astroblemes: $\oplus$ 
Geochronologic data (rock ages): show at selected oceanic sites, particularly DSDP sites that reach oceanic basement, as $\mathrm{K} / \mathrm{Ar}$ ages of basalt, or as paleontologic ages of overlying sedimentary rocks.

Paleomagnetic data: selected points, at which arrow shows azimuth of pa$311^{\circ}$ leomagnetic north with respect to present true north. A dashed line -normal to the tail of the arrow is labeled with value of paleolatitude $11^{\circ} \$$ and its geological age.

Depth to basement rocks or specified horizon: show indirectly by isopach lines $(1,3,5 \mathrm{~km})$ for continental areas to foot of continental slope, or by hundreds of meters (written 1, 2, 3, etc.) for ocean areas, except that travel time in half-seconds can be used if necessary. Color of isopach lines to indicate age $r$ ange of covering rocks (black if unknown).

\section{BOUNDARIES}

Map-unit boundary: black line as on Geologic Map.

Boundary between continental and oceanic crust: generally shown by limit of distribution of oceanic crustal rocks, and in special cases by a map-unit boundary line.

Inner edge of continent affected by rifting and breakup (shown where data available): $\ldots \ldots \ldots$

\section{ROCKS OF ACTIVE PLATE MARGINS}

Igneous rocks and undifferentiated sediments in present active plate margins in modern arc regions: overprints for igneous lithologies as on geologic map, and for sediments pattern of short horizontal dashes, closely spaced; patterns in color indicating age range of rocks, on white background.

\section{CONTINENTAL CRUST}

\section{Basement rocks}

Metamorphic rocks, including complexes with metamorphosed igneous rocks (eg., gneisses, charnockites, metabasalts, etc): as on Geologic Map, with solid color showing age of major metamorphism.

Intrusive igneous rocks: as on Geologic Map, with solid color showing age of intrusion, except distinguish ultramafic intrusives (black) and ophiolites (purple) where possible. Indicate geologic age of ophiolite with appropriate letter symbols. 
Table 18, pg. 3

Open-File Report 85-267

Deformed sedimentary and volcanic rocks (those generally deemed to be too deformed to contain hydrocarbons): to be shown by color to indicate age of major deformation, with black overprints for volcanic 1ithologies as on Geologic Map. Accretionary prisms or melange belts can be distinguished by an added line pattern showing trends of strata.

2. Rocks of transitional and reactivation basins

Transitional sequences*: deposits immediately succeed major deformation and immediately precede platform-strata deposition. Show by black map-unit boundary line (broken where concealed), with inner band of dots and dashes colored to indicate age range of rocks. Where deformed, fill area of unit with horizontal hatching (broken into long dashes where concealed) colored to indicate.

Igneous rocks include mostly felsic volcanics, bimodal volcanics, and post-kinematic granites and associated volcanics. Sedimentary rocks include molasse-like deposits, commonly in foredeeps and grabens.

Reactivation sequences: deposits are unrelated to preceding tectonism, except for inherited structural control. Rocks include some foredeep, graben and molasse-1ike deposits, and volcanics. Show by black map-unit boundary line with inner geometric dot-pattern banding in color indicating age range of rocks.

\section{Covering rocks}

Continental-platform strata, including many "sedimentary basins", and also blanket deposits not in tectonic downwarps: the stratigraphic boundaries (unconformities; limits of preservation) of major tectonic or or lithologic significance to be shown in black, with parallel bands in color to indicate age range of unit. Within boundaries, pastel tints present age of basement where known.

\section{Continental margin deposits:}

*Rift sequence: presence indicated by showing the thick deposits that accumulate in the rift valleys of shelves preceding continental breakup and sea-floor spreading; shown by an open circle pattern, color indicating age range of deposits.

* As this unit is unfamiliar to many, it is described in more than usual detail. 
Table 18, pg. 4

Open-File Report 85-267

*Drift sequence: deposits that accumulate over rift sequences and the rest of the contemporaneous shelf area after breakup; shown by a heavy dot pattern, color indicating age range of deposits.

Concealed rifts shown by dotted line colored to indicate age of inception.

Intraplate igneous rocks (plateau basalts and other anorogenic intrusives and extrusives): indicate kind of rock by pattern used on Geologic Map, but colored to show age; show basement in the same way as for continental-platform strata.

\section{TECTONIC ELEMENTS}

The active crustal plates have been identified on the Plate-Tectonic Map. Each plate can be divided into tectonic regions, such as fold belts and shields, on the basis of gross differences in structure and physiography. Such regions can be named on the Tectonic Map where their configurations are recognizable by the distribution of rock units, or possibly on an inset map. The names of tectonic sub-regions can be introduced in some places, if desirable.

CRUSTAL THICKNESS (for possible inclusion as a smal1-scale inset map)

Mohorovicic depth map: depth-contour interval $5 \mathrm{~km}$ above $10 \mathrm{~km}$ and $1 \mathrm{~km}$ below $10 \mathrm{~km}$; if shown, propose a single compiler of worldwide data.

* Rift and drift sequences are characteristic of the "passive margin" tectonic setting of continental shelves. 
Table 18, pg. 5

Open-File Report 85-267

STRUCTURAL AND TECTONIC FEATURES

Letter Symbol

A

$A^{1}$

$A^{2}$

PA

PA $^{1}$

$\mathrm{BA}^{2}$

$\mathrm{RA}^{3}$

$\mathbf{E}_{1}$

$\mathrm{e}_{1}^{1}$

$\mathrm{P}_{1}^{2}$
AUSTRALIA-INDIA, ANTARCTICA AND PACIFIC PLATES

Structural Name \&

Age Span

ARCHAEAN (3500-2500 Ma)

Pilbara Block

3500-2900 Ma

Yilgarn Block

3700-2500 Ma

PROTEROZOIC-ARCHAEAN

Rum Jungle Block (Complex) $2500 \mathrm{Ma}$

Namambu Complex

(not on the T/S plot)

2500-1800 Ma

Hamersley Basin

2700-2100 Ma

UNDIFFERENTIATED PROTEROZOIC

Antarctica, undiff. basement
Tectonic Setting (interpretation)

\& Brief Description

Australian cratonic nucleif

Granitoid-greenstone terrain

Archaean orogenic setting

Proto-continental high-grade gneiss terrain (in the west; 3700-3000 Ma) and granitoidgreenstone terrain (in the east, about 2700 Ma old)

Granitoid and gneiss dome terrain (2500 Ma); younger metasediments, metadolerite and B.I.F.

Granitoid and gneiss dome terrane (2500-2400 Ma) gneisses mantled by leucogneisses and schists

Cratonic cover - platform basin over Pilbara Block. Cratonic flood basalts overlain by sediments, including B.I.F.

Orogenic domain, metamorphics

EARLY PROTEROZOIC (2500-1700 Ma)

Litchfield Complex

(not on the $\mathrm{T} / \mathrm{S}$ plot)

(2500-1800 Ma)

$\frac{\text { Granitoid }}{\text { (about 2500-2400 Ma), deformed }}$ and metamorphosed $1800 \mathrm{Ma}$.

Capricorn Orogen (Ashburton Fold Belt, Gascoyne Prov., Glengarry Sub-basin) 2000-1700 Ma

Orogenic domain, sediments and volcanics metamorphosed and deformed 1700 Ma. Granitoids 1900-1600 Ma. 
$\mathbf{B}_{1}^{3}$

Halls Creek Inlier (Prov. ince) $2800-1960 \mathrm{Ma}$

$\mathrm{e}_{1}^{4}$

$\mathrm{e}_{1}^{5}$

Kimberley Basin

18i5-1760 Ma

$\mathrm{e}_{1}^{6}$

Pine Creek Inlier

(Palmerston Province)

2400-1690 Ma

$\mathbf{e}_{1}^{7}$

$\mathrm{e}_{1}^{8}$

$\mathrm{e}_{1}^{9}$

Kalkadoom-Leichhardt Block

$\mathrm{P}_{1}^{10}$

$\mathrm{e}_{1}^{11}$ 1870-1780 Ma

The Granites-Tanami

Inlier (Block)

$>1960-1680 \mathrm{Ma}$

Arnhem Inlier (Block)

Murphy In1ier

Tennant Creek Inlier

(Block)

>1920-1660 Ma
Orogenic domain (Mobile zone) sedimentation \& igneous activity 2800 to $2200 \mathrm{Ma}$, deformation \& metamorphism $1960 \mathrm{Ma}$.

Late orogenic domain (transitional), felsic volcanics, granites \& sediments about $1900 \mathrm{Ma}$ old; final deformation before $1750 \mathrm{Ma}$.

Cratonic cover - platform over Halls Creek Inlier (Province rocks. Marine sediments \& cratonic extrusives \& intrusives; dolerite sills about $1760 \mathrm{Ma}$ old.

Orogenic domain sedimentation \& igneous activity 2400-1940 Ma. Metamorphism about 1870-1800 Ma. Granites 1890 \& $1760 \mathrm{Ma}$. Doler1te lopolith $1690 \mathrm{Ma}$.

Orogenic domain, metamorphism 1945 Ma.

Orogenic domain, metamorphism $1945 \mathrm{Ma}$, late orogenic granite \& volcanics $1770 \mathrm{Ma}$.

Late orogenic domain (transtional, felsic volcanics \& granites $1860 \mathrm{Ma}$; granite \& metamorphism 1740-1700 Ma.

Orogenic domain (?) mobile be1t), metamorphism of sediments and volcanics $1810 \mathrm{Ma}$, overlain by sandstone \& volcanics of late orogenic character. Granites 1770-1680 Ma.

Orogenic domain, marine sediments, felsic \& mafic volcanics metamorphosed $1920 \& 1810$ $\mathrm{Ma}$. Late orogenic domain represented by rocks $1790-1660 \mathrm{Ma}$. 
Table 18, pg. 7

Open-File Report 85-267

$\mathrm{E}_{1}^{12}$

Arunta Block

$>1810-1770 \mathrm{Ma}$
Orogenic domain (mobile belt), some older orogenic rocks correlated with Halls Creek Inlier, followed by sediments \& volcan1cs $1800 \mathrm{Ma}$. Metamorphism \& granite 1810-1770 Ma. 
Table 19. Compilation guidelines for the Energy Resources Map Series (revised January 12, 1984)

Background for Energy-Resources Map

LAND AREAS

Basement terrane

Proterozoic Sedimentary and Volcanic Rocks

Metamorphic Complexes

Intrusive Rocks of Phanerozoic Age

Volcanic Cover

Foreland Thrust Belts

Surficial deposits

Sa1t domes

Sedimentary basins

Sediment Isopachs - from the Tectonic Map Series

Basin Names - to be selected by each pane1 (Coury and Hendricks, 1978, and St. John, 1980 are suggested references). To be shown on map, if possible; otherwise in explanatory booklet. Northeast Quadrant plans to include names on index map in the booklet.

Border Line of Basin - if needed to define basin

OCEAN AREAS

Bathymetry - from the Geographic Map Series

Sediment Isopachs - from the Tectonic Map Series

Selected DSDP Stratigraphic Columns - from the Geologic Map Series

Major Active Plate Boundaries - from the Plate-Tectonic Map Series 
Table 19, pg. 2

Open-File Report 85-267

Energy Resources

Oil and gas

Large or closely spaced small fields
Small

field (color)

(green)

(red)

Gas

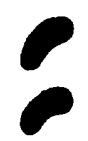

$\begin{array}{ll} & \text { (green) } \\ - & \text { (red) }\end{array}$

Giant fields1/ - identified by name on map and on index map

Generalized stratigraphic column2/ - compiled for each basin with giant oil or gas field and for selected other basins, as needed

Oil sands

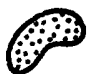

(green)

Oil shale - minimum grade to be shown 40 liter/ton

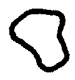

(blue)

Coal

Anthracite and semianthracite

Bituminous

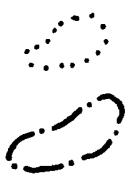

(brown)

(brown)

Subbituminous

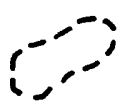

(brown)

Lignite

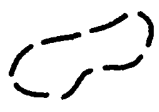

(brown)

Rank not identified

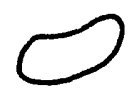

(brown)

Age of coal (to be indicated--

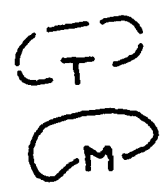

Tertiary (lignite)

if known--by letter same as geologic-map symbol)

Definition - each panel to describe criteria for what is mapped (e.g., "potentially recoverable") 
Table 19, pg. 3

Open-File Report 85-267

\section{Geothermal energy}

Heatflow spot data - values in excess of $200 \mathrm{milliwatts} / \mathrm{m}^{2}$ to be printed alongside symbol. Data provided by David Chapman and Uk Han, University of Utah.

\section{Milliwatts $/ \mathrm{m}^{2}$}

$<25$

$$
\begin{aligned}
& 25-50 \\
& 50-75
\end{aligned}
$$$$
75-100
$$$$
100-150
$$$$
150-200
$$$$
>200
$$

\section{Geothermal convection system}

Developed hydrothermal convection

$$
\text { system }
$$

$>150^{\circ} \mathrm{C}$.

$$
\text { Vapor dominated - steam and }
$$$$
\text { vapor-dominated dry steam }
$$

Hot water

$$
90^{\circ}-150^{\circ} \mathrm{C} \text {. }
$$

Hot water

\section{Symbol}

$\Delta$ (black)

$\Delta \quad$ (purple)

$\Delta$ (blue)

$\Delta$ (green)

$\Delta$ (brown)

$\Delta \quad$ (orange)

$\Delta \quad$ (red)

- (red) + name

- (blue) + name 
Table 19, pg. 4

Open-File Report 85-267

Symbol

\begin{tabular}{|c|c|c|}
\hline \multicolumn{3}{|l|}{ system } \\
\hline \multicolumn{3}{|l|}{$\begin{array}{l}>150^{\circ} \mathrm{C} . \text { (estimated mean } \\
\text { reservoir temperature) }\end{array}$} \\
\hline Vapor dominated & $\diamond$ & (red) \\
\hline Hot water & 0 & (red) \\
\hline \multicolumn{3}{|l|}{$\begin{array}{c}90^{\circ}-150^{\circ} \mathrm{C} . \text { (estimated mean } \\
\text { reservoir temperature) }\end{array}$} \\
\hline Hot water & 0 & (blue) \\
\hline$\frac{\text { Hot spring with surface temperature }}{\text { above } 50^{\circ} \mathrm{C} \text {. and not evaluated }}$ & 0 & (green \\
\hline
\end{tabular}

Explanatory Notes Booklet

To include resources data and illustrative material such as stratigraphic columns, cross sections, index maps, discussion of map elements, and any of the above material that cannot be accommodated on the map. Outline of suggested contents and sample illustrations under preparation by Northeast Quadrant Panel and to be completed and sent to other panels during January 1984.

1/ Giant fields, for the purposes of Circum-Pacific compilation, are defined as having ultimate reserves of 100 million barrels of oil or 600 billion cubic feet of gas. K. J. Drummond plans to identify these by number keyed to a list in the explanatory notes booklet for the Northeast quadrant. For North American fields that are not in Pacific margin basins, such as the Midcontinent area, Drummond recommends using 500 million barrels and 300 trillion cubic feet as lower limits.

2/ Stratigraphic sections to show occurrence of oil or gas. Drummond to provide other panels with sample plot during early 1984 . 
Table 20. Letter from Peter B. Humphrey to Michel T. Halbouty concerning a Circum-Pacific hazards map.

Dr. Michel T. Halbouty

Consulting Petroleum Geologist

5100 Westheimer Road

Houston, Texas 77056

Dear Dr. Halbouty:

A few ideas come to mind regarding your proposal for a natural hazards map in the CPMP series. A colleague here, Dr. Mark Valencia, recently completed a similar effort for Southeast Asia and has offered to share his data with you. A xerox of his summary map is attached (see figure 14)--it may provide a few ideas to those in charge of your map. Notice especially the manner in which typhoon tracks are plotted: percentage values serve to indicate their probability of occurrence in a given area; the months indicated are those in which that occurrence is most likely. I believe this is a good type of data set, though I would be more inclined to integrate as much historical data as possible into a probability pattern overlaying the entire Pacific map, e.g., a dark pattern along the Hong Kong coast would indicate typhoons as an annual event and a light pattern over Tahiti would indicate greater rarity. I would also like to suggest the addition of:

1) dots or a pattern for known tornado areas (land)

2) dots or a pattern for reported waterspout areas (sea)

3) dots reporting historical freak waves

4) dashed lines to indicate the summer and winter limits of pack ice

5) dashed lines to indicate the summer and winter limits of icebergs

6) dark coloration of coasts and valleys that experience habitual flooding

7) moderate coloration of coasts and valleys that experience modest flooding

8) a pattern indicating common north and south Pacific storm area (differentiating these annual events from the rarer hurricanes/ typhoons )

Putting all this data on one map would be an invaluable contribution. Best of luck to you on this magnificent enterprise!

Sincerely,

Peter B. Humphrey

Marine Geology Fellow

Resource Systems Institute

East-West Center

University of Hawaii 
Table 21. Proposed compilation guidelines for a 1:17,000,000-scale EnergyResources Map of the Pacific Basin.

\section{Energy Resources}

Hydrocarbons :

Oil and gas fields - represent by colored areas (green for oil and red for gas) to show location of oil and gas fields in each basin, making these as representative of the actual area as possible.

Giant fields - identify by number (as in Halbouty and others, 1970) alongside red or green colored blob (possibly using leader). Number keyed to table in explanatory booklet.

Coal - generalized from 1:10,000,000-scale map, possibly showing only coal basins or areas.

Geotherma1: adapt from 1:10,000,000-scale map.

Ocean thermal gradients: (from Frank H. Wang's 1982 compilation).

Background

Basins: indicate by outline around basin; use colored tints to show thickness.

Ocean areas: isopachs generalized from 1:10,000,000-scale map; plate boundaries and motion vectors from Plate-Tectonic Map (delete numerical values).

Sediment thickness: use color tints to indicate thickness.

Faults: except where correction is needed, take directly from PlateTectonic Map.

Basement rock exposed: indicate by pattern.

Extensive volcanic cover: indicate by pattern.

Areas underlain by salt domes: indicate by pattern.

Holocene volcanoes and areas of high heat flow: if space permits.

Tectonic provinces: generalize whatever appears on the Tectonic Map affecting energy resources and depict by patterns.

I Compiled by W. O. Addicott from outline by P. W. Richards and notes by K. J. Drummond, 6-18-83. 
Table 21, pg. 2

Open-File Report 85-267

\section{Explanatory Booklet}

Index map for basin names (possibly at 1:40,000,000 scale).

Representative stratigraphic sections for basins containing giant fields.

Index map showing basins containing ofl and gas fields of the Circum-Pacific keyed by number and tabulated showing number of giant fields (as in Halbouty and others, 1970). On map show shield areas, fold belts, oceanic plate boundaries and fracture zones. 
Table 22. Report of a Meeting on the Southeast Asia Project, Madrid, Apri1 2-4, 1984 .

An ad hoc meeting of Circum-Pacific Map Project, CCOP, and IUGS representatives was convened in Madrid, Spain, April 2-4, 1984, through the efforts of Richard Sinding-Larsen. Dr. Arthur Saldivar-Sali, Chairman of the meeting, said that the purpose of the meeting would be to outline the specific products for this project in Southeast Asia.

John A. Reinemund, representing the Circum-Pacific Map Project, described the progress to date of the Circum-Pacific Map Project and provided copies of the base maps for the Circum-Borneo area, and for the Japan-Korea area at scales of $1: 2,000,000$ and $1: 2,500,000$. The latter scale was considered by the group to be the more desirable for publication, although compilation could be undertaken more conveniently at the $1: 2,000,000$ scale.

Ernest P. DuBois of CCOP presented a review of the pilot project in the circumBorneo aera, including the background, developments, and current status of the activity. A comprehensive discussion by DuBois is included as Attachment 1 to this report. The meeting commented on the major accomplishments that have been made as an excelllent demonstration of the feasibility of the program proposals.

The relationships between identified requirements for resource assessment and the products prepared by Charles Masters of the U.S. Geological Survey were reviewed by the group. Each of the items identified by Masters, and anticipated to be products within each project, were seen to be necessary. The relationships are summarized in Attachment 1 along with some additional desirable products.

Saldivar-Sali then described the following series of steps to be taken as a work program:

1) Continue the pilot project with completion expected by the end of 1984 .

2) Luki Witoelar of Indonesia to report the results of the Madrid meeting to ASCOPE meeting probably at their May or June 1984 meeting.

3) Transfer of technology and training in assessment methodology could begin in 1985.

4) Coordination of compilation for the seven map sheets (Figure 14) for the seven maps was recommended as follows:

area 1 would probably be led by Japan area 2 would probably be led by China area 3-7 leadership should be left for ASCOPE to assign.

Witoelar had expressed a desire to have the work on these quadrangles start simultaneously if possible. 


\title{
Summary of Regional Mapping Program of CCOP/ASCOPE
}

\author{
by Ernest P. Dubois
}

Within the aera represented by ASCOPE (Asean Council on Petroleum) i.e., Indonesia, Malaysia, Philippines, Singapore, and Thailand, the current wave of petroleum exploration had its beginnings in the mid-1960s, and continues until the present. Exploration is largely conducted under work contractor--production sharing contracts carried out under supervision of state oil agencies authorized to act in such a role.

Public release of the geologic results of such exploration has commonly taken place through local journals and publications of somewhat restricted circulation, e.g., Indonesian Petroleum Association (IPA), Geological Society of Malaysia, and South East Asia Petroleum Exploration Society (SEAPEX). Few of these articles are concerned with concepts of a regional nature; most deal with areas of restricted geographic extent. It should be noted that an exception exists in regard to the heat flow maps of Indonesia and Southeast Asia issued by IPA and SEAPEX.

The first major regional report in recent times was the Tectonic Map of Indonesia authoried by Warren Hamilton and published by USGS, about 1978 . Release of the map was followed within a year or so by publication of a major descriptive text (Professional Paper 1078) which undertook to describe the geology of the area in plate tectonic terms.

About the same time CCOP and ASCOPE, at first separately and later in cooperation, undertook a series of exercises aimed at publication of maps and reports emphasizing the regional aspects of petroleum geology in the ASCOPE region.

The first attempt at relating ofl and gas distribution to sediment thickness simply overlaid a map of oil and gas occurrences over the W. Hamilton map. This was followed by a cooperative program with ASCOPE at which time ASCOPE released a compiled structure map of the South China Sea, accompanied by (largely) seismic cross sections. Publication of the ASCOPE/CCOP South China Sea report encouraged both organizations to extend the program to include the areas of the Andaman SeaMalacca Strait, and the complex area of the Sulu Sea-Makassar Strait-East Java Sea. Publication of the results of these last named areas is expected to take place in late 1984, and an up-dated and revised report, with maps and cross sections, combining the three areas (South China Sea, Andaman Sea, and Sulu Sea-Java Sea), is expected in 1985.

Throughout this period, beginning in 1979, CCOP has tried to develop a regional program which, in effect, would extend the CCOP/ASCOPE ef fort to include the entire CCOP region. Emphasis on a CCOP-regional program attracted the attention of IUGS and CPMP and has resulted in the development of a program in which collaboration appears to be assured between IUGS, CPMP, ASCOPE, and CCOP. 
Table 22, pg. 3

Open-File Report 85-267

To demonstrate the practicality of such an approach, it was agreed that a pilot project be undertaken of the offshore area surrounding the island of Borneo.

To this end, the USGS supplied CCOP with the services of a geologist (Keith Robinson) to prepare a set of maps designed to illustrate the petroleum geology offshore Borneo and to lay the ground work for an assessment of the same area.

Incidental and necessary to the proposed CCOP regional project was the preparation of a series of compatible base maps, with updated bathymetry. These maps are now under preparation by the USGS and will cover essentially the offshore areas of the CCOP region (see figure 14). An example of the base sheet for area 1 (figure 2) was displayed in the meeting.

The pilot project has resulted in several maps including a revised structural cum sediment-thickness map, thickness and paleogeographic reconstructions of the Neogene and Paleogene, and basin distribution map.

In the course of developing the pilot project maps, a great deal of additional material was obtained, including much from industry. It is now apparent that for the southern portion of the CCOP area (and the pilot area itself), it is possible to prepare the following regional maps (displays):

(1) Structure and sediment thickness map of the Tertiary (i.e., "depth to basement" map, where basement may be metamorphosed lower Tertiary or pre-Tertiary).

(2) Individual thickness maps of Tertlary subdivisons, e.g., P1io-Pleistocene, Miocene, Oligocene, and Eocene.

(3) Lithofacies maps of same intervals; it is probably desirable to combine these with the preceding maps.

(4) Paleo-environmental reconstructions of the same.

(5) Compilations of gravity and air-mag data to assist in depth-to-basement exercises in areas where direct information is absent.

(6) For each basin, cross section(s), correlation chart, typical well section(s), and field descriptions as available.

(7) For each basin (as appropriate), and regionally, oil and gas distribution and exploratory well map. Where information is available, or can be estimated, field size distribution graphs, and King Hubbert-type charts of discovery rate per unit of exploratory drilling, including time parameters.

(8) Geothermal gradient and heat-flow maps for individual basins, and regionally. 
Table 22, pg. 4

Open-File Report 85-267

(9) As possible, collection and portrayal especially of total organic content and thermal maturity, data on individual basins. This might be done in connection with (6), above.

These may be extended throughout the CCOP area as desirable. 
Table 23. Production schedule for the Southeast Asia 1:2,000,000-scale base maps (figure 14).

$\begin{array}{clll} & & \text { Bathymetry } & \text { Topography } \\ \text { Sheet } 1 & \text { Japan and Korea } & \text { completed } & \text { Oct. 15, } 1985 \\ \text { Sheet } 3 & \text { Thailand } & \text { completed } & \text { Dec. 1, } 1985 \\ \text { Sheet } 5 & \text { Malaysia and Indonesia west } & \text { completed } & \text { Jan. 15, } 1986 \\ \text { Sheet } 4 & \text { Philippines } & \text { Feb. 7, 1985 } & \text { March 1, } 1986 \\ \text { Sheet } 2 & \text { China } & \text { March 28, 1985 } & \text { April 15, } 1986 \\ \text { Sheet } 6 & \text { Indonesia east } & \text { May 15, 1985 } & \text { June 1, } 1986 \\ \text { Sheet } 7 & \text { Papua New Guinea and Solomons } & \text { July 31, 1985 } & \text { July 31, } 1986\end{array}$

The target for completion of bathymetry and topography for all seven sheets is July $31,1986$. 